\title{
BÁRBARA KAWAMURA
}

Avaliação de um novo candidato a fármaco para o tratamento do carcinoma de pulmão de células não pequenas

Dissertação apresentada à Faculdade de Medicina da Universidade de São Paulo para a obtenção do título de Mestre em Ciências

Programa de Ciências Médicas Área de Distúrbios do Crescimento Celular, Hemodinâmicos e da Hemostasia

Orientador: Adilson Kleber Ferreira

São Paulo 
Dados Internacionais de Catalogação na Publicação (CIP)

Preparada pela Biblioteca da

Faculdade de Medicina da Universidade de São Paulo

Creprodução autorizada pelo autor

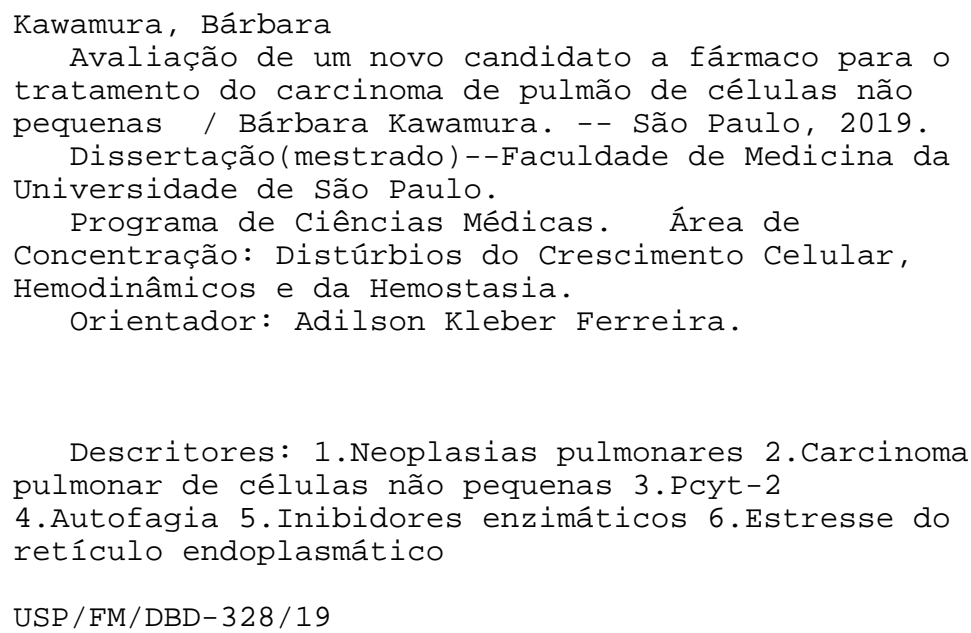

Responsável: Erinalva da Conceição Batista, CRB-8 6755 
O projeto foi financiado pela Coordenação de Aperfeiçoamento Pessoal de Nível Superior (CAPES) e pela Fundação de Amparo à Pesquisa do Estado de São Paulo (FAPESP) sob o número de processo de 2017/00497-3, através da concessão da bolsa de mestrado. Este projeto também foi vinculado ao projeto de apoio a jovens pesquisadores da FAPESP através do processo número 2015/18528-7.

Este trabalho foi realizado em colaboração com o Prof. Dr. José Alexandre Marzagão Barbuto, no Laboratório de Imunologia de Tumores do Departamento de Imunologia do Instituto de Ciências Biomédicas da Universidade de São Paulo através do projeto universal do Conselho Nacional de Desenvolvimento Científico e Tecnológico (CNPq) número 409825/2016-6. 


\section{AGRADECIMENTOS}

Ao meu orientador Dr. Adilson Kleber Ferreira, pela confiança, oportunidade, suporte, incentivo e possibilitar o desenvolvimento desse projeto.

Ao Prof. Dr. José Alexandre Marzagão Barbuto, por abrir as portas do seu laboratório, ceder o espaço, compartilhar equipamentos, materiais e reagentes, além da imensa contribuição científica e acadêmica.

À Sarah Fernandes Teixeira, pela companhia do dia-a-dia, pela amizade, pela inteligência que transborda e inspira, pelas trocas de conhecimento e por todo o apoio que me dá desde o início.

À Lisley Inata Mambelli, pelos anos de amizade, por ser aquela amiga de todas as horas, por ser um exemplo de bondade e profissionalismo em pessoa.

Ao Salomão Doria Jorge, pela amizade, pelos momentos de descontração e pelo conhecimento compartilhado.

Aos "barbutinhos": Aline, Beth, Célia, Gabi, Mari, Nádia, Patty e Thi, por serem exemplos de determinação, fontes de conhecimento e por tornarem os dias mais leves pelo simples fato da companhia.

Ao meu namorado, Eduardo Uemura, pelo amor, apoio, incentivo e companheirismo durante todos esses anos.

Aos meus pais, Emília e Roberto, e irmãos, Jéssica e Russell, pelo amor e apoio incondicional de sempre.

A todos que colaboraram de forma direta e indireta para a realização desse trabalho. 
"Só se vê bem com o coração, o essencial é invisível aos olhos".

O pequeno príncipe - Antoine de Saint-Exupéry 


\section{Sumário}

Lista de siglas e símbolos

Lista de figuras

Lista de tabelas

Resumo

Abstract

1 INTRODUÇÃO

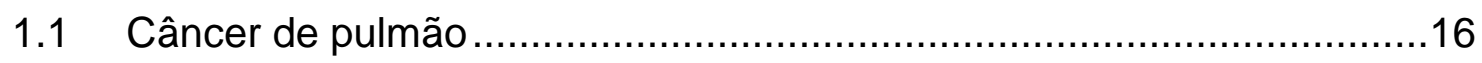

1.2 Pcyt-2 como alvo para o planejamento de novos agentes antitumorais 17

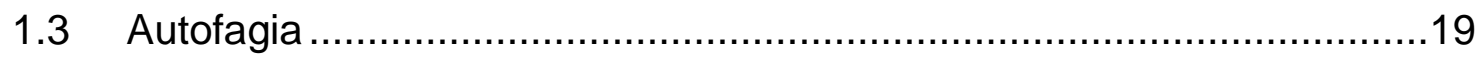

1.4 Desenvolvimento do um potencial agente antitumoral .........................21

2 OBJETIVO

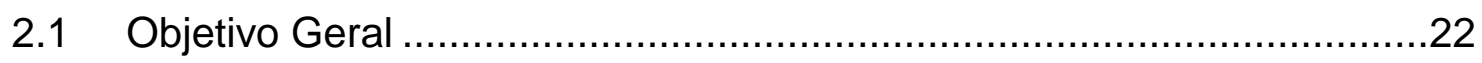

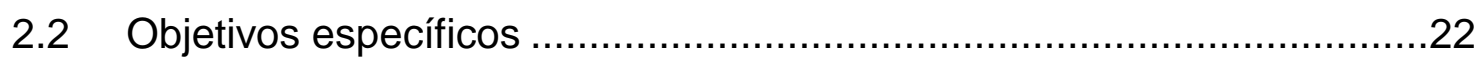

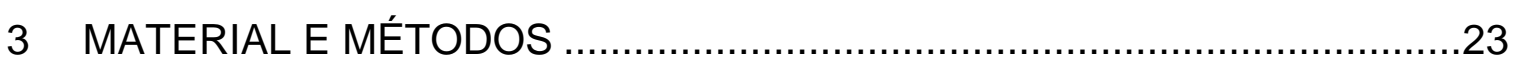

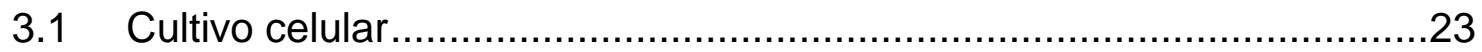

3.2 Avaliação dos efeitos citotóxicos pelo método MTT ...............................23

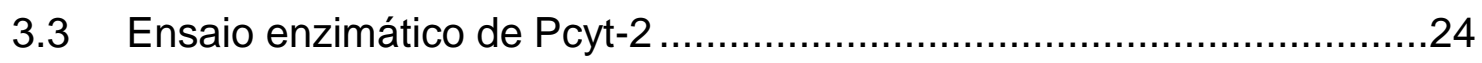

3.4 Ensaio de apoptose por Anexina V/iodeto de propídio (PI) ..................25

3.5 Avaliação do potencial de membrana mitocondrial $(\Delta \psi \mathrm{m}) \ldots \ldots \ldots \ldots \ldots \ldots \ldots . . . . .25$

3.6 Avaliação da citotoxicidade em Cultura 3D ........................................26

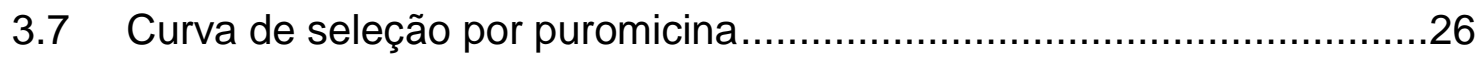

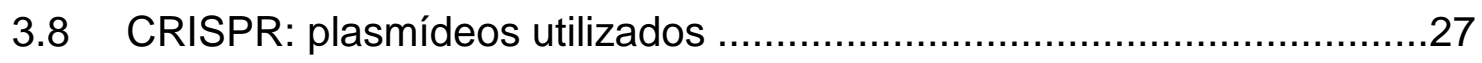

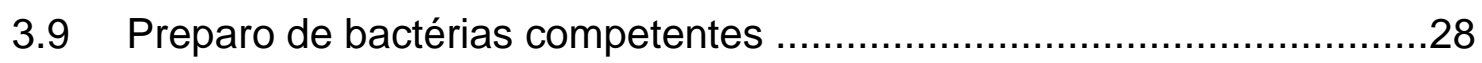

3.10 Transformação de bactérias TOP10 e DH5a com plasmídeos de

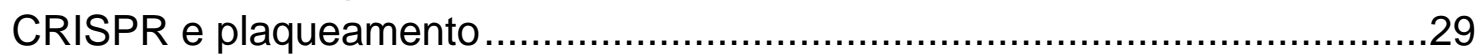

3.11 Extração e purificação dos plasmídeos por mini-preparação (MiniPrep)30

3.12 Padronização da técnica de transfecção celular por eletroporação .......31

3.13 Transfecção celular por eletroporação ...............................................31

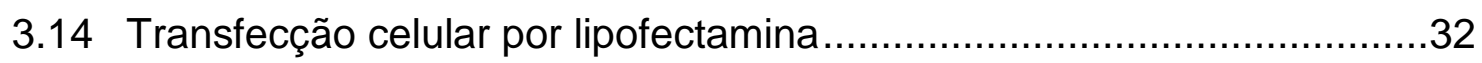

3.15 Curva de seleção por puromicina.....................................................

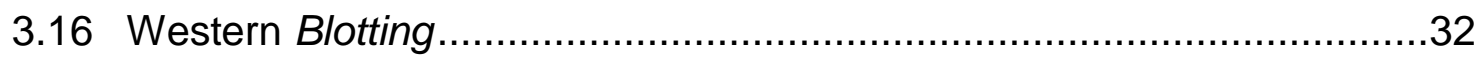


3.17 Microscopia Eletrônica de Transmissão (MET) ……….......................33

3.18 Análise estatística dos resultados ......................................................

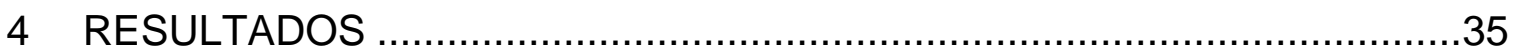

4.1 Avaliação dos efeitos citotóxicos dos quimioterápicos cisplatina, paclitaxel e o do anticorpo monoclonal bevacizumab nas células de CPCNP.35

4.2 Determinação da eficácia da combinação terapêutica do CHY-1 com os agentes utilizados na primeira linha de tratamento de CPCNP

4.3 Avaliação das proteínas envolvidas no processo autofágico e estresse de retículo endoplasmático

4.4 Avaliação dos efeitos citotóxicos do composto SF2, um intermediário

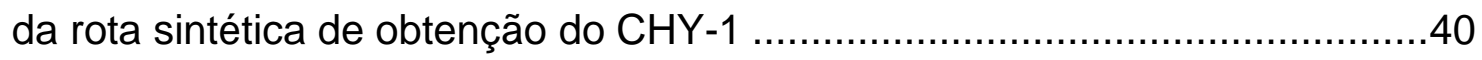

4.5 Avaliação dos efeitos de SF2 na enzima Pcyt-2 …............................41

4.6 Avaliação dos mecanismos de morte celular por SF2 ….......................42

4.7 Avaliação do potencial de membrana mitocondrial ..............................43

4.8 Transformação de bactérias competentes com plasmídeos de CRISPR46

4.9 Determinação da concentração de puromicina para seleção de células

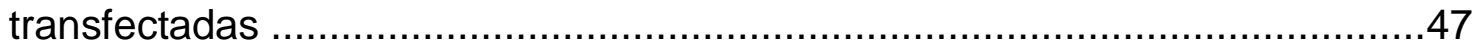

4.10 Padronização da técnica de transfecção celular por eletroporação .......48

4.11 Transfecção celular por eletroporação ..............................................52

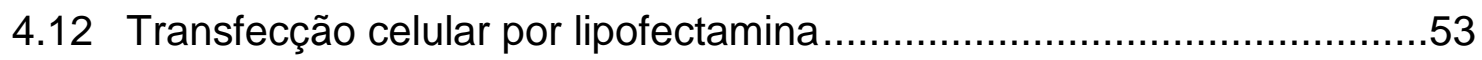

4.13 Avaliação das proteínas envolvidas no processo autofágico ..................53

4.14 Confirmação do silenciamento por CRISPR/cas9 …….........................54

4.15 Avaliação das proteínas envolvidas no processo autofágico nas células silenciadas

4.16 Ensaio de citotoxicidade para avaliação dos efeitos da combinação de SF2 com cisplatina na linhagem A549 WT e silenciadas ..............................57

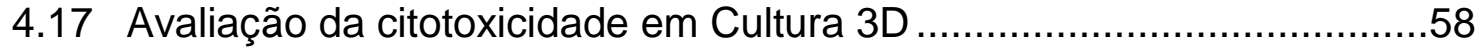

4.18 Avaliação das alterações morfológicas induzidas por SF2 …...............61

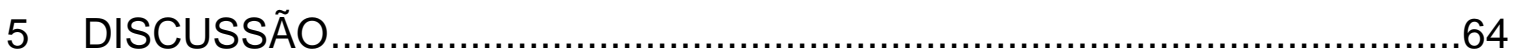

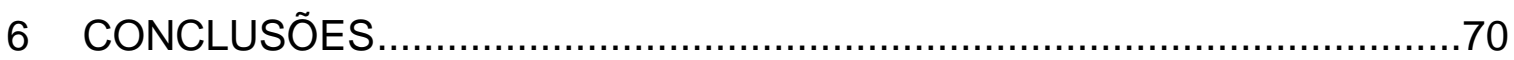

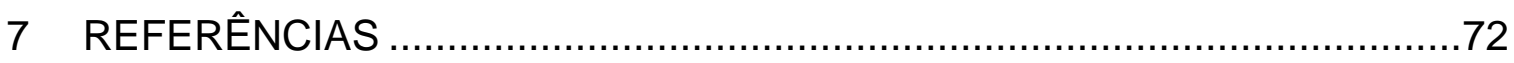




\section{LISTA DE SIGLAS E SÍMBOLOS}

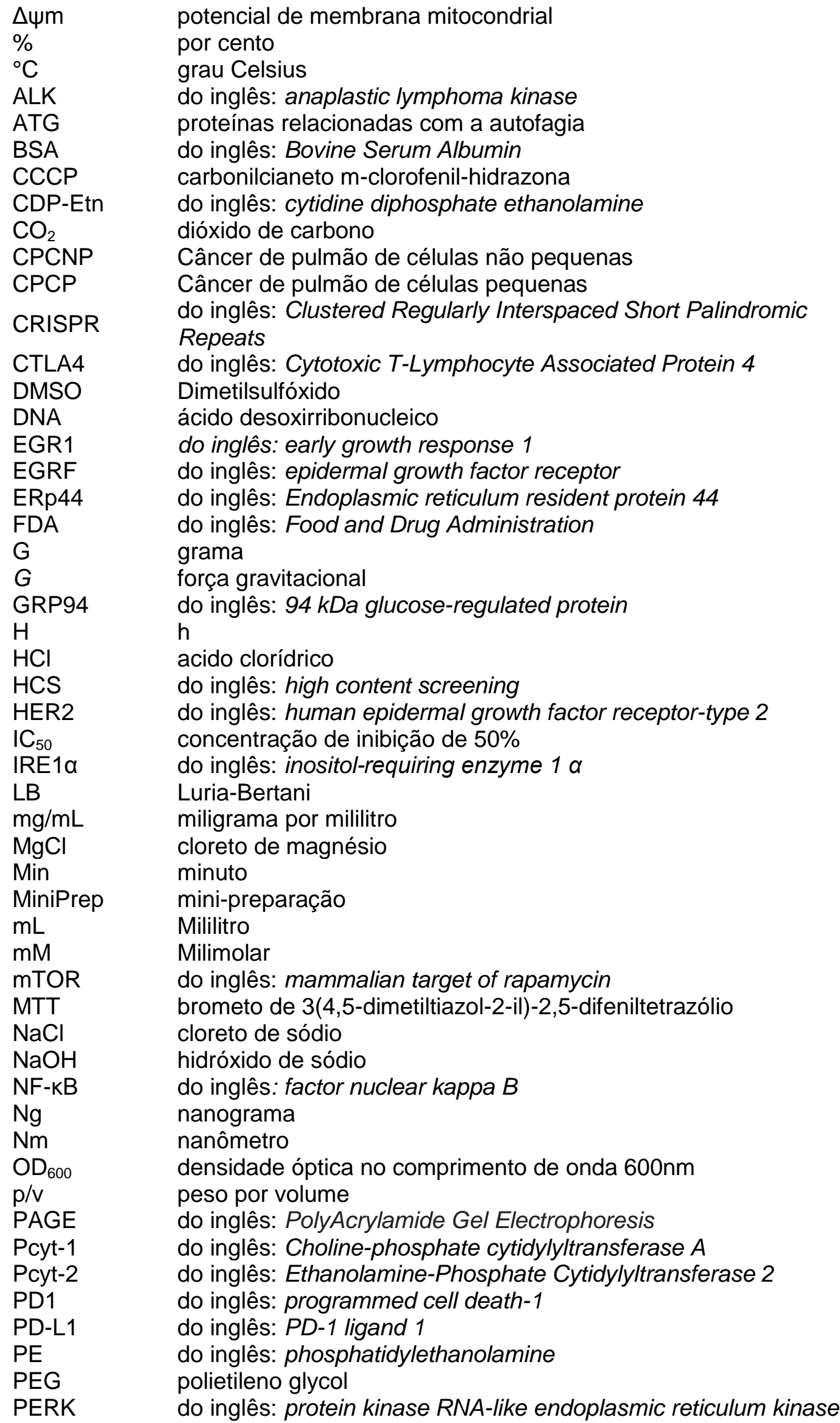




$\begin{array}{ll}\text { PEtn } & \text { do inglês: phosphoethanolamine } \\ \text { pGFPmax } & \text { plasmídeo contendo o gene GFP } \\ \text { pH } & \text { potencial hidrogeniônico } \\ \text { PI } & \text { iodeto de propídio } \\ \text { PI3K } & \text { fosfatidilinositol 3-quinase } \\ \text { PVDF } & \text { fluoreto de polivinilideno } \\ \text { RE } & \text { retículo endoplasmático } \\ \text { RMN } & \text { ressonância magnética nuclear } \\ \text { ROS } & \text { do inglês: reactive oxygen species } \\ \text { Rpm } & \text { rotação por minuto } \\ \text { SDS } & \text { dodecil sulfato de sódio } \\ \text { TMRE } & \text { tetrametilrodamina } \\ \text { TRAIL } & \text { do inglês: Tumor necrosis factor (TNF)-related apoptosis-inducing } \\ \text { TSS } & \text { ligand } \\ \text { TTBS } & \text { do inglês: Transformation and Storage Solution } \\ \text { UPR } & \text { tampão de Tris-salino com Tween-20 } \\ \text { v/v } & \text { do inglês: unfolded protein response } \\ V E G F-A & \text { volume por volume } \\ \mu C i & \text { do inglês: Vascular endothelial growth factor A } \\ \mu g & \text { microcurie } \\ \mu g / m L & \text { micrograma } \\ \mu L & \text { microgramas por mililitro } \\ \mu L & \text { microlitro } \\ \mu M & \text { microlitro } \\ { }^{1} \mathrm{H} & \text { micromolar } \\ { }^{13} \mathrm{C} & \text { Hidrogênio } \\ { }^{14} \mathrm{C} & \text { carbono 13 } \\ & \text { carbono 14 }\end{array}$




\section{LISTA DE FIGURAS}

Figura 1. Os efeitos da combinação de $\mathrm{CHY}-1$ com bevacizumab, cisplatina e paclitaxel sobre a viabilidade celular de CPCNP.

Figura 2. Análise das proteínas relacionadas ao estresse de retículo endoplasmático e autofagia em A549.

Figura 3. Análise das proteínas relacionadas ao estresse de retículo endoplasmático e autofagia em $\mathrm{NCl}-\mathrm{H} 460$.

Figura 4. Ensaio de anexina V/PI em células A549...................................... 42

Figura 5. Ensaio de anexina V/PI em células H460................................... 42

Figura 6. Alteração do potencial de membrana mitocondrial para A549. ......... 44

Figura 7. Alteração do potencial de membrana mitocondrial para $\mathrm{H} 460$.......... 45

Figura 8. Crescimento bacteriano em placa LB-ágar..................................... 46

Figura 9. Curva de seleção por puromicina.................................................. 47

Figura 10. Transfecção de células A549 com pGFPmax............................... 49

Figura 11. Padronização da técnica CRISPR/Cas9 na linhagem de células A549 utilizando o gene repórter GFP com a solução SF. ................................ 50

Figura 12. Padronização da técnica CRISPR/Cas9 na linhagem de células A549 utilizando o gene repórter GFP com a solução SE.. ………................. 51

Figura 13. Controle positivo da transfecção celular A549 por pGFPmax......... 52

Figura 14. Análise das proteínas relacionadas à autofagia em A549............... 54

Figura 15. Confirmação do silenciamento dos genes ATG5, ATG7 e Beclin-1.55

Figura 16. Análise das proteínas relacionadas à autofagia em A549 selvagem e

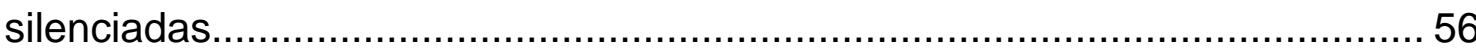

Figura 17. Ensaio de citotoxicidade em cultura 3D de células A549............... 59

Figura 18. Ensaio de citotoxicidade em cultura 3D de células MRC-5 GFP+.. 60

Figura 19. Avaliação das alterações morfológicas em A549 induzidas por SF2 e combinações. 


\section{LISTA DE TABELAS}

Tabela 1. Composição do meio de cultura LB .............................................. 28

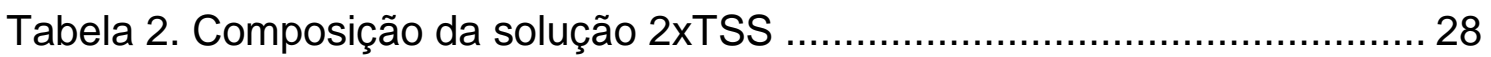

Tabela 3. Composição do meio de cultura SOC …………………............... 29

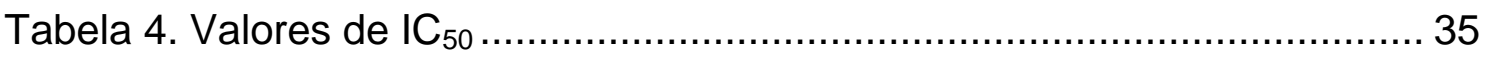

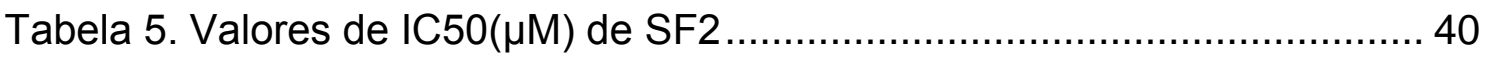

Tabela 6. Valores de teste da atividade da enzima Pcyt2 isolada.................... 41

Tabela 7. Valores representativos da produção de etanolamina e CDP-Etn quando células MCH58 foram tratadas com meclizina e SF2 ......................... 41

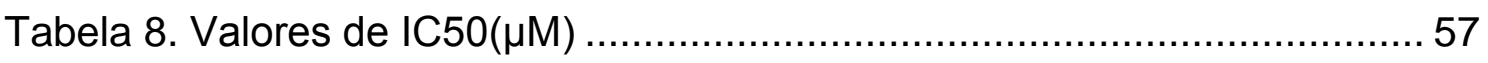

Tabela 9. Porcentagens de viabilidade celular …........................................ 57 


\section{RESUMO}

KAWAMURA B. Avaliação de um novo candidato a fármaco para o tratamento do carcinoma de pulmão de células não pequenas [dissertação]. São Paulo: Faculdade de Medicina, Universidade de São Paulo, 2019.

O carcinoma de pulmão é um dos tumores malignos mais incidentes e letais no mundo e possui, na maioria dos casos, um prognóstico desfavorável. Devido ao insucesso relativo dos protocolos terapêuticos atuais, há uma urgente necessidade de desenvolvimento de novos tratamentos. A enzima CTP:fosfoetanolamina citidililtransferase (Pcyt-2), que utiliza a fosfoetanolamina (PEtn) como substrato, é um regulador chave na via de Kennedy para a produção de fosfatidiletanolamina (PE). Este fosfolipídio é um dos mais abundantes nas células eucarióticas e, por conseguinte, a redução de sua produção poderia afetar diretamente a divisão celular, a autofagia e a apoptose. Em um estudo prévio, foi confirmado que a Pcyt-2 é um alvo terapêutico em células de câncer de pulmão e foram identificados dois novos compostos, protótipos para o desenvolvimento racional de inibidores da enzima Pcyt-2: o CHY-1 e o SF2. O objetivo desse trabalho foi avaliar os efeitos citotóxicos e os mecanismos inibitórios na autofagia dos novos compostos em carcinoma de pulmão de células não pequenas (CPCNP). Os resultados indicaram que $\mathrm{CHY}-1$ apresenta efeito in vitro superior ao paclitaxel e cisplatina, além disso, a combinação em dose sub-tóxica de CHY-1 com cisplatina e $\mathrm{CHY}-1$ com paclitaxel apresentaram efeitos citotóxicos superiores aos respectivos ativos isolados. Além disso, CHY-1 foi capaz de induzir estresse do retículo endoplasmático (RE) e reduzir o fluxo autofágico. Possivelmente o SF2, um intermediário de CHY-1, está relacionado estruturalmente com o seu grupo farmacofórico. No modelo tridimensional com a linhagem A549, foi observado que a combinação de cisplatina com SF2 é muito mais eficiente quando comparado com os tratamentos individuais, desestabilizando o esferoide pela perda de matriz extracelular. Entretanto os mesmos resultados também foram observados para MRC-5, um fibroblasto não tumoral. Foi demonstrado que o SF2 inibe a enzima Pcyt-2 e o transporte de etanolamina para $\circ \mathrm{RE}$, e, desta maneira, reduz a produção de $\mathrm{PE}$. Os resultados do ensaio de Anexina/PI indicaram que a combinação de SF2 com cisplatina induz preferencialmente apoptose, entretanto, não apresentaram efeitos sinérgicos. O SF2 foi capaz de reduzir o potencial elétrico da membrana mitocondrial das células A549 e NCl-H460, indicando a participação mitocondrial no processo de morte celular. Além disso, o SF2 se mostrou capaz de diminuir o fluxo autofágico, observado pela diminuição das proteínas: ATG5, ATG7, Beclin-1 e LC3 I e II, por Western blotting, resultados semelhantes ao previamente demonstrado por $\mathrm{CHY}-1$ na linhagem A549. Pela técnica de CRISPR/Cas9 (do inglês: Clustered Regularly Interspaced Short Palindromic 
Repeats), foram obtidas as células A549 knockout para os genes envolvidos no processo autofágico: ATG5, ATG7 e Beclin-1. Os resultados obtidos mostraram que, por mais que todas essas proteínas estejam relacionadas com a autofagia, as células se comportaram diferente para cada silenciamento. As imagens obtidas por MET corroboram com a hipótese de que SF2 inibe a via autofágica de forma diferente da cloroquina, além de induzir alterações morfológicas da mitocôndria e RE. SF2 tem potencial para se tornar um fármaco antitumoral pela inibição da enzima Pcyt-2, levando a apoptose e redução do fluxo autofágico em modelos de CPCNP, entretanto ainda são necessários mais estudos e uma possível modificação na estrutura da molécula para potencializar o seu efeito e melhorar a seletividade a células tumorais.

Descritores: Neoplasias pulmonares; Carcinoma pulmonar de células não pequenas; Pcyt-2; Autofagia; Inibidores enzimáticos; Estresse do retículo endoplasmático 


\section{ABSTRACT}

KAWAMURA B. Evaluation of new drug candidate for the treatment of nonsmall cell lung cancer. [Dissertation]. Sao Paulo: "Faculdade de Medicina, Universidade de Sao Paulo", 2019.

Lung cancer is one of the most incident and lethal malignant tumors in the world and has, in most cases, an unfavorable prognosis. Due to the relative failure of current therapeutic protocols, thus, new treatments are urgently required. The enzyme CTP: phosphoethanolamine cytidylstransferase (Pcyt-2), which uses phosphoethanolamine as substrate, is the key regulator of the Kennedy pathway for phosphatidylethanolamine (PE) production. This phospholipid is one of the most abundant in eukaryotic cells and, therefore, the reduction of its production could directly affect cell division, autophagy and apoptosis. In a previous study, it was confirmed that Pcyt-2 is a therapeutic target in lung cancer cells and two new compounds were identified, prototypes for the rational development of Pcyt-2 enzyme inhibitors: CHY-1 and SF2. The aim of this study was to evaluate the cytotoxic effects and inhibitory mechanisms on autophagy of new compounds in non-small cell lung cancer (NSCLC). The results indicated that $\mathrm{CHY}-1$ has superior in vitro effect than paclitaxel and cisplatin, in addition, the sub-toxic dose combination of $\mathrm{CHY}-1$ with cisplatin and $\mathrm{CHY}-1$ with paclitaxel had superior cytotoxic effects than the isolated drugs. Besides, $\mathrm{CHY}$ 1 was able to induce endoplasmic reticulum (ER) stress and reduce autophagic flux. Possibly SF2, an intermediate of $\mathrm{CHY}-1$, is structurally related to its pharmacophoric group. In the three-dimensional model with the A549 cells, it was observed that the combination of cisplatin with SF2 is more efficient when compared to individual treatments, destabilizing the spheroid due to loss of extracellular matrix. However the same results were also observed for MRC-5, a non-tumor fibroblast. SF2 has been shown to inhibit the enzyme Pcyt-2 and transport of ethanolamine to the ER, thereby reducing PE production. Using the Annexin / PI assay indicated that the combination of SF2 with cisplatin preferentially induces apoptosis, however, did not show synergistic effects. SF2 was able to decrease mitochondrial membrane potential of A549 and $\mathrm{NCl}-\mathrm{H} 460$ cells, indicating mitochondrial participation in the cell death process. In addition, SF2 was able to decrease autophagic flux, observed by the reduction of proteins: ATG5, ATG7, Beclin-1 and LC3 I and II, by Western blotting, results similar to those previous shown by CHY-1 in A549 cells. By CRISPR / Cas9 technique (Clustered Regularly Interspaced Short Palindromic Repeats), A549 knockout cells were obtained for the genes involved in the autophagic process: ATG5, ATG7 and Beclin-1. The results showed that, although all these proteins are related to autophagy, the cells behaved differently for each silencing. The images obtained by MET corroborate the hypothesis that SF2 inhibits the autophagic pathway differently from chloroquine, besides inducing 
morphological alterations of mitochondria and RE. SF2 has the potential to become an antitumor drug by inhibiting the Pcyt-2 enzyme, leading to apoptosis and reduction of autophagic flux in NSCLC models. However, further studies and a possible modification of the molecule structure are still needed to enhance its effect and improve selectivity to tumor cells.

Descriptors: Lung neoplasms; Carcinoma non-small-cell lung; Pcyt-2; Autophagy; Enzyme inhibitors; Endoplasmic reticulum stress. 


\section{INTRODUÇÃO}

O câncer é uma das principais doenças que acomete populações de todos os países e regiões, sendo estimado 18 milhões de novos casos e 9,5 milhões de óbitos em 2018 em todo mundo (1). No Brasil, o Instituto Nacional de Câncer (INCA) estima, para o biênio 2018-2019, 600 mil novos casos para cada ano (2). Estudos indicam que o processo de tumorigênese em humanos é um processo de múltiplas etapas em que as alterações genéticas levam à transformação progressiva das células normais em malignas (3).

O carcinoma pulmonar, considerado raro até o início do século $X X$, é um dos tipos de tumores malignos de maior incidência no mundo e com alta taxa de mortalidade (4)(5). No Brasil, são estimados 18.740 novos casos de câncer de pulmão entre os homens e 12.530 entre as mulheres (2). Deste modo, é inquestionável que esta doença mantém-se como um desafio à saúde pública nacional e mundial, mesmo com os avanços das pesquisas e da tecnologia em novas estratégias no combate ao câncer. Consequentemente, a busca por novas abordagens terapêuticas e o desenvolvimento de novos medicamentos são urgentemente necessários.

\subsection{Câncer de pulmão}

Na prática clínica, os carcinomas de pulmão são classificados em diferentes tipos histológicos, que podem ser ainda agrupados sob duas designações: 0 câncer de pulmão de células pequenas (CPCP), que representa cerca de 15\% do total de casos, e, o câncer de pulmão de células não pequenas (CPCNP), responsável por mais de $80 \%$ da incidência do câncer de pulmão (6)(7). Estes tipos de canceres são relativamente insensíveis à quimioterapia, mas, quando detectados precocemente, podem ser ressecados completamente, aumentando a sobrevida mediana dos pacientes para cinco anos entre 20 e $70 \%(8)(9)$.

Os pacientes confirmados em estágios iniciais (estágio I ou II) de CPCNP são, na maioria das vezes, submetidos à cirurgia, e eventualmente combinada 
à quimioterapia adjuvante (10). No entanto, aproximadamente $61 \%$ dos pacientes recém-diagnosticados com CPCNP apresentam doença avançada (estágio III ou IV), pois os estágios iniciais costumam ser assintomáticos (11). Nestes casos, preconiza-se a quimioterapia e/ou a radioterapia, visando estender a sobrevida, e melhorar a qualidade de vida dos pacientes (12).

Com os avanços científicos, algumas terapias alvos-direcionadas surgiram para as mutações em EGRF (do inglês: epidermal growth factor receptor) (13), BRAF (14) e HER2 (do inglês: human epidermal growth factor receptor-type 2) (15), e para os rearranjos em de ALK (do inglês: anaplastic lymphoma kinase) (16) e ROS1 (17), entretanto, menos da metade dos adenocarcinomas pulmonares apresentam uma dessas alterações, além dos casos de resistência serem frequentes (18). Mais recentemente, a imunoterapia tem revolucionado a área da oncologia. Alguns inibidores de CTLA4 (do inglês: Cytotoxic TLymphocyte Associated Protein 4), PD1 (do inglês: programmed cell death-1) e PD-L1 (do inglês: $P D-1$ ligand 1), por exemplo, apresentam resultados promissores e já estão sendo utilizados na clínica (TANVETYANON et al, 2017; HOFMAN et al, 2019; WANG et al, 2019), porém o elevado custo ainda é um empecilho ao sistema de saúde, limitando o amplo acesso da população (19). Deste modo, o desenvolvimento de novas abordagens terapêuticas mais eficazes e economicamente viáveis contra o câncer de pulmão é o objetivo principal das novas terapias.

\subsection{Pcyt-2 como alvo para o planejamento de novos agentes antitumorais}

Os fosfolipídios são componentes essenciais para a formação da bicamada lipídica das células e estão relacionados aos processos de crescimento, proliferação, diferenciação, sobrevivência, apoptose, inflamação, motilidade, autofagia, etc (20)(21). As células tumorais passam por uma adaptação metabólica com a finalidade de aumentar o aporte de substratos intermediários, tais como, proteínas, ácidos nucléicos e lipídios (22). Entre os fosfolipídios mais abundantes estão a fosfatidilcolina e a fosfatidiletanolamina (PE, do inglês: phosphatidylethanolamine), cuja principal via de síntese é a via de Kennedy, 
tornando-os alvos interessantes para o desenvolvimento de novas terapias (23)(24).

A via de Kennedy apresenta duas rotas, uma para a produção de fosfatidilcolina e a outra de PE. As duas rotas são semelhantes, utilizando os precursores colina e etanolamina para a conversão em seus respectivos fosfolipídios. As etapas limitantes das rotas são controladas pelas enzimas CTP:fosfocolina-citidilil-transferase (Pcyt-1, do inglês: Choline-phosphate cytidylyltransferase A) e CTP:fosfoetanolamina-citidilil-transferase (Pcyt-2, do inglês: Ethanolamine-Phosphate Cytidylyltransferase 2), portanto, possíveis alvos terapêuticos (20).

O primeiro fosfolipídio antineoplásico aprovado foi a miltefosina para o tratamento tópico de metástases cutâneas do câncer de mama, além de ser utilizado também no tratamento de leishmaniose (25). Ela atua como um inibidor da Pcyt-1, induzindo, por conseguinte, à apoptose devido a deficiência de colina e ao aumento dos níveis de ceramida (26)(27). Entretanto, seu uso clínico é limitado, pois apresenta efeitos adversos no sistema gastrointestinal e ação hemolítica (28).

Gohil e colaboradores demonstraram que o fármaco meclizina, utilizado clinicamente em intervenções profiláticas para o controle de náuseas e vertigens, potencialmente inibe a via de Kennedy, por um mecanismo de inibição enzimática não competitiva da enzima Pcyt-2. Esta inibição é responsável por elevar a concentração intracelular da fosfoetanolamina (PEtn, do inglês: phosphoethanolamine), o principal substrato da enzima Pcyt-2 na via de Kennedy. Devido ao acúmulo deste substrato, a meclizina inibe a respiração mitocondrial induzindo morte celular (29).

Devido aos avanços dos estudos moleculares, foi possível conhecer melhor as propriedades moleculares da Pcyt-2, que são diretamente dependentes da estrutura química e de sua atividade biológica (30)(31). Estudos do grupo da Profa. Dra. Bakovic demonstraram que alguns fatores de transcrição associados a tumores, como o NF-kB (do inglês: factor nuclear kappa $B$ ) e o EGR1 (do inglês: early growth response 1) podem controlar a expressão do 
gene PCYT2, e por sua vez, estão associados a elevação da atividade enzimática da Pcyt-2 (32)(33).

\subsection{Autofagia}

Outro processo em que a PE exerce um papel importante é durante a autofagia. A autofagia é um processo evolutivamente conservado de degradação e manutenção celular tanto em condições fisiológicas quanto patológicas (34)(35). Há três tipos de autofagia: a microautofagia, a autofagia mediada por chaperonas e a macroautofagia. A microautofagia é um processo de degradação lisossomal não seletivo, que envolve o engolfamento do citosol através da invaginação da sua membrana (36). A autofagia mediada por chaperonas não envolve reorganização da membrana, ao invés disso, proteínas solúveis são translocadas para o interior do lisossomo pelo desdobramento das proteínas chaperonas (37). Já a macroautofagia é o tipo mais estudado e geralmente é referida por apenas autofagia, ela é caracterizada pela formação de vesículas intracelulares de dupla membrana chamadas de autofagossomos que se fundem com lisossomos, formando os autofagolisossomos (38).

Em condições fisiológicas, a autofagia está ativa em níveis basais, reciclando componentes citoplasmáticos como os aminoácidos, as proteínas mal dobradas, os ácidos graxos e até as organelas, a fim de manter a homeostasia, renovar os componentes celulares e fornecer energia (39)(40). Em condições adversas, como privações de nutrientes, danos celulares, infecções por microrganismos, estresse, etc, a via autofágica é superestimulada (41)(42)(43).

Nas células saudáveis, autofagia desempenha um papel importante como supressora tumoral por manter a integridade genômica e mitocondrial das células, eliminando as proteínas e as organelas danificadas (principalmente as mitocôndrias, que liberam as espécies reativas de oxigênio (ROS: do inglês: reactive oxygen species)), e até mesmo outras células (canibalismo) (44)(45). Entretanto, no ambiente tumoral, a autofagia atua de formas diferentes, 
dependendo do tipo celular e do estágio em que se encontra o tumor (46). No início da tumorigênese, a via da autofagia é ativada de forma protetora, eliminando células com potencial tumoral e impedindo a transformação maligna e a progressão do tumor (47). Porém, em estágios mais avançados, a autofagia acaba contribuindo com a sobrevivência e a proliferação das células tumorais, uma vez que auxilia no fornecimento de nutrientes, dificultando a eliminação e aumentando a resistência aos tratamentos (48).

Atualmente, o único inibidor autofágico aprovado para uso clínico pelo FDA (do inglês: Food and Drug Administration) é a cloroquina e seu derivado, a hidroxicloroquina (49). Esses fármacos são indicados para o tratamento da malária, amebíase hepática, artrite reumatoide, lúpus e doenças que provocam sensibilidade dos olhos à luz (50)(51). Em 1970, durante um estudo dos diversos efeitos adversos, Bedoya observou que a cloroquina era citotóxica em células tumorais (52). Apenas em 1998, Murakami e colaboradores correlacionaram a cloroquina com a inibição da autofagia (53). O mecanismo de ação da cloroquina, por ser uma base fraca, consiste em sequestrar os prótons, elevando o pH lisossomal. A desacidificação do lisossomo impede a sua fusão com o autofagossomo, assim inibindo a degradação do conteúdo autofagossomal (21).

Desde então, diversos trabalhos foram publicados demonstrando a eficácia da combinação da cloroquina com outros quimioterápicos no combate ao câncer (54)(55)(56)(57). Entretanto, apesar da sua eficiência, a cloroquina e seus derivados causam retinopatia, podendo ser irreversível, além de progredir mesmo depois de cessado o seu uso (58). Por isso a busca por novos inibidores mais seletivos e eficazes são necessários. 


\subsection{Desenvolvimento do um potencial agente antitumoral}

Em estudos prévios do grupo, uma quimioteca de novas entidades químicas como potenciais inibidores da enzima Pcyt-2 foi planejada com o auxílio de computador. Os métodos de modelagem molecular e de quimiometria foram aplicados na investigação de um conjunto de oitenta derivados de éter fosfolípides, previamente descritos na literatura como antiparasitários (59)(60). $\mathrm{Na}$ análise exploratória, os compostos foram separados em dois grandes grupos e no grupo onde estavam os fármacos de referência (miltefosina, edelfosina, erufosina e perifosina), estava também o composto que foi denominado $\mathrm{CHY}-1$, o qual foi selecionado para ser sintetizado e avaliado em relação ao efeito farmacológico. Este composto também foi ancorado no sítio de interação da enzima Pcyt-2, cujas coordenadas cartesianas foram depositadas no banco de dados de proteínas, PDB (61).

Após a síntese de $\mathrm{CHY}-1$, alguns estudos preliminares foram feitos pelo grupo. Os primeiros testes foram os de citotoxicidade em cultura 2D de CPCNP, demonstrando eficácia superior aos protótipos da classe. Além desse estudo, foi feito outro em colaboração com a Profa. Dra. Marica Bakovic, Universidade de Guelph, Canadá, utilizando o isótopo radioativo $\left[{ }^{14} \mathrm{C}\right] \mathrm{PE}$ tn, foi possível confirmar a capacidade do $\mathrm{CHY}-1$ em inibir de forma não competitiva a atividade catalítica da Pcyt-2 in vitro e a redução da produção de PE. Com esses resultados, foi dado início a esse projeto, cujo objetivo inicial era aprofundar os estudos do mecanismo de ação desse novo composto. Entretanto, após ter iniciado os experimentos com o CHY-1, houve um problema em uma das etapas de síntese e purificação, não sendo possível o isolamento do composto numa pureza adequada. A alternativa encontrada foi testar os compostos intermediários da reação que puderam ser isolados, visando identificar o grupo farmacofórico ou uma molécula similar. Por esse motivo, foi dada continuidade no projeto com a molécula denominada SF2. 


\section{OBJETIVO}

\subsection{Objetivo Geral}

Avaliar os mecanismos inibitórios do CHY-1 e do SF2 na autofagia em carcinoma de pulmão de células não pequenas e seu possível efeito sinérgico in vivo com o agente quimioterápico cisplatina.

\subsection{Objetivos específicos}

- Determinar os efeitos citotóxicos do CHY-1 e SF2 e possíveis efeitos sinérgicos com o agente quimioterápico cisplatina em culturas 2D e 3D nas células A549 e NCl-H460;

- Avaliar da indução de apoptose nos diferentes tipos celulares (A549 e $\mathrm{NCl}-\mathrm{H} 460$ ), pelo tratamento com CHY-1 e SF2;

- Elucidar os efeitos inibitórios do CHY-1 e SF2 na autofagia nas células A549 e NCl-H460. 


\section{MATERIAL E MÉTODOS}

\subsection{Cultivo celular}

As linhagens de CPCNP (A549, NCl-H1299, NCl-H292 e NCl-H460), e as células fibroblasto de pulmão MRC-5 $\mathrm{GFP}^{+}$foram mantidas em meio RPMI1640 com $10 \%(\mathrm{v} / \mathrm{v})$ de soro fetal bovino. Já as células MRC-5, foram mantidas em meio alpha-MEM com $10 \%(\mathrm{v} / \mathrm{v})$ de soro fetal bovino. Os meios utilizados em todas as células foram suplementados com solução estabilizada de penicilina (100 unidades $/ \mathrm{mL}$ ), estreptomicina $(100 \mu \mathrm{g} / \mathrm{mL})$ e $0,5 \%(\mathrm{p} / \mathrm{v}) \mathrm{de}$ anfotericina $\mathrm{B}$. Todas estas células foram cultivadas a $37^{\circ} \mathrm{C}$ com $5 \%$ de $\mathrm{CO}_{2}$. As linhagens celulares utilizadas foram adquiridas da American Type Culture Colection (Manassas, EUA) ou do Banco de Células do Rio de Janeiro (Rio de Janeiro, Brasil), com exceção da MRC-5 GFP ${ }^{+}$, que foram cedidas Pault Ferruzo, do laboratório de Sinalização Molecular do Instituto de Química da Universidade de São Paulo - USP. Ao atingirem a subconfluência, as culturas foram ampliadas e as células foram criopreservadas em solução de soro fetal bovino com $10 \%$ de dimetilsulfóxido (DMSO) a $-80 \stackrel{\circ}{\circ}$.

\subsection{Avaliação dos efeitos citotóxicos pelo método MTT}

Para a avaliação dos efeitos citotóxicos foi realizado o teste colorimétrico do MTT [brometo de 3(4,5-dimetiltiazol-2-il)-2,5-difeniltetrazólio]. As células foram semeadas na densidade de $10^{4}$ células/poço em placas de 96 poços e, após a adesão, tratadas com cada fármaco ou composto (CHY-1, cisplatina, paclitaxel, bevacizumab ou SF2), com concentrações variadas, por $24 \mathrm{~h}$. Em seguida, foram adicionados $10 \mu \mathrm{L}$ de MTT (Sigma-Aldrich, MO, EUA) a $5 \mathrm{mg} / \mathrm{mL}$ em cada poço e a placa foi incubada por $3 \mathrm{~h}$. As placas foram então centrifugadas a $300 \mathrm{~g}$ por $10 \mathrm{~min}$, o meio foi removido e os cristais de formazam diluídos em $100 \mu \mathrm{L}$ de DMSO. O cálculo de viabilidade celular foi realizado através das densidades ópticas obtidas utilizando 0 leitor de microplacas (VERSAmaxTunableMicroplate Reader, Molecular Devices, CA, EUA) em 
comprimento de onda de $538 \mathrm{~nm}$. Os valores de absorbância são correlacionados a viabilidade celular, sendo os poços controle, ou seja, as células sem tratamento equivalentes a $100 \%$ de viabilidade celular. O cálculo estimado da concentração de $\mathrm{IC}_{50}$ foi feito a partir da curva dose-resposta de cada fármaco, utilizando o software GraphPadPrism, versão 7 (LaJolla, San Diego, CA, EUA).

\subsection{Ensaio enzimático de Pcyt-2}

Em colaboração com a Profa. Dra. Marica Bakovic, University of Guelph, Canadá, foi determinada a atividade de Pcyt-2. $50 \mu \mathrm{L}$ de tampão Tris- $\mathrm{HCl} 20$ mM, pH 7,8, $\mathrm{MgCl}_{2} 10$ mM, DTT 5 mM, CTP 650 uM, PEtn não marcada 650 $\mu \mathrm{M}$ e $\left[{ }^{14} \mathrm{C}\right]$ PEtn 65 uM foi misturado com $0,4 \mu \mathrm{g}$ de Pcyt-2 purificada a $37^{\circ} \mathrm{C}$ durante $15 \mathrm{~min}$. As reações foram interrompidas fervendo a solução por $2 \mathrm{~min}$. A meclizina $50 \mu \mathrm{M}$ ou o SF2 $60 \mu \mathrm{M}$ foram adicionados na mistura reacional. As misturas foram então colocadas sobre placas de gel de sílica $G$ com padrões de CDP-Etn (do inglês: cytidine diphosphate ethanolamine) e PEtn e separadas num sistema solvente contendo metanol, $\mathrm{NaCl}$ a $0,5 \%$, amónia (50: 50: 5). As placas foram então pulverizadas com ninhidrina a $1 \%$, e o produto CDP-Etn foi quantificado por contagem de cintilação líquida.

Para a radiomarcação dos intermediários da via Kennedy, fibroblastos MCH58 foram cultivados na presença de $25 \mu \mathrm{M}$ de meclizina ou $25 \mu \mathrm{M}$ de SF2 durante $5 \mathrm{~h}$ a $60 \%$ de confluência, em seguida $\left[{ }^{14} \mathrm{C}\right]$ etanolamina $(0,5$ $\mu \mathrm{Ci} /$ placa) foi adicionada, e as células foram incubadas por $24 \mathrm{~h}$. Os lipídios foram extraídos utilizando o método de Bligh e Dyer. A radioatividade total da fase água/metanol e a da fase lipídica foram medidas separadamente. $\left[{ }^{14} \mathrm{C}\right]$ PEtn foi separada da fase lipídica utilizando cromatografia de camada fina em solvente constituído por metanol/clorofórmio/amónia (65: 35: 5). Etanolamina e CDP-Etn foram separadas da fase água/metanol utilizando cromatografia de camada fina numa solução de metanol, $\mathrm{NaCl}$ a 0,5 \%, amônia (50: 50: 5). Os compostos separados marcados com ${ }^{14} \mathrm{C}$ foram medidos por contagem de cintilação. 


\subsection{Ensaio de apoptose por Anexina V/iodeto de propídio (PI)}

As células apoptóticas foram quantificadas utilizando o kit Dead Cell Apoptosis (Molecular Probes) com anexina $\mathrm{V}$ Alexafluor 488 e iodeto de propidio (PI). Foram semeadas $10^{4}$ células $/ \mathrm{mL}$ (A549 ou NCl-H460) em placas escuras de 96 poços. Depois de $24 \mathrm{~h}$ de adesão, foram tratadas com cisplatina (70 $\mu \mathrm{M}$ para A549 e $18 \mu \mathrm{M} \mathrm{NCl-H460),} \mathrm{SF2} \mathrm{em} \mathrm{três} \mathrm{concentrações:} \mathrm{(20} \mathrm{\mu M,} 40$ $\mu \mathrm{M}$ e $80 \mu \mathrm{M}$ para A549 e $15 \mu \mathrm{M}, 30 \mu \mathrm{M}$ e $60 \mu \mathrm{M}$ para NCl-H460) e TRAIL 5 $\mu \mathrm{g} / \mathrm{mL}$ como controle positivo de morte celular. Após $24 \mathrm{~h}$ de tratamento, as células foram incubadas por $4 \mathrm{~h}$ com Hoechst $332585 \mu \mathrm{g} / \mathrm{mL}$ (Molecular Probes) e 30 min a $4{ }^{\circ} \mathrm{C}$ com anexina $\mathrm{V}$ conjugada com Alexafluor 488 (1:50) em tampão de ligação e com $20 \mu \mathrm{g}$ de PI (Molecular Probes). Para análise dos ensaios, foi utilizado o aparelho ImageXpress Micro-Wide Field High Content Imaging System (Molecular Devices, Sunnyvale, CA) em colaboração com a Dra. Débora Levy do laboratório de Genética e Hematologia Molecular (LIM 31), FMUSP, São Paulo.

\subsection{Avaliação do potencial de membrana mitocondrial $(\Delta \psi \mathrm{m})$}

O potencial de membrana mitocondrial foi analisado através de uma sonda catiônica, a éster etílico tetrametilrodamina (TMRE). Foram semeadas $10^{4}$ células/mL (A549 ou NCl-H460) em placas escuras de 96 poços. Depois de 24 $\mathrm{h}$ de adesão, foram tratadas com cisplatina (70 $\mu \mathrm{M}$ para A549 e $18 \mu \mathrm{M}$ para a linhagem NCl-H460) e com SF2 em três concentrações: $(20 \mu \mathrm{M}, 40 \mu \mathrm{M}$ e 80 $\mu \mathrm{M}$ para $\mathrm{A} 549$ e $15 \mu \mathrm{M}, 30 \mu \mathrm{M}$ e $60 \mu \mathrm{M}$ para $\mathrm{NCl}-\mathrm{H} 460)$. Após $24 \mathrm{~h}$ de tratamento, as células foram incubadas por $4 \mathrm{~h}$ com Hoechst $332585 \mu \mathrm{g} / \mathrm{mL}$ (Molecular Probes) e por $45 \mathrm{~min}$ a $37 \stackrel{\circ}{\circ} \mathrm{com}$ TMRE $50 \mathrm{nM}$. Um dos poços foi tratado por 10 min com $100 \mu \mathrm{M}$ carbonilcianeto m-clorofenil-hidrazona (CCCP), utilizado como controle positivo para despolarização de membrana. Para análise dos ensaios, foi utilizado o aparelho ImageXpress Micro-Wide Field High Content Imaging System (Molecular Devices, Sunnyvale, CA) em 
colaboração com a Dra. Débora Levy do laboratório de Genética e Hematologia Molecular (LIM 31), FMUSP, São Paulo.

\subsection{Avaliação da citotoxicidade em Cultura 3D}

A fim de avaliar a atividade citotóxica de SF2, células tumorais (A549) e não tumorais (MRC5), foram cultivadas em um sistema de cultura 3D. O sistema de levitação magnética (n3D Biosciences, Inc., Greiner bio-one) foi utilizado para a formação dos esferoides. Em um tubo cônico, as células foram separadas, considerando $1,5.10^{4}$ células por esferoide, e para cada $10^{4}$ células foram utilizados $1 \mu \mathrm{L}$ de nanopartícula. As células com as nanopartículas foram homogeneizadas e centrifugadas por 5 min a $300 \mathrm{~g}$, três vezes. Em seguida, foram semeadas em placa de 96 poços, não aderente. A placa foi repousada sobre a placa magnética por $24 \mathrm{~h}$, e ficou mais $24 \mathrm{~h}$ em cultura sem a placa, para estabilização dos esferoides. Após esse período de $48 \mathrm{~h}$, o meio de cultura foi trocado e foram realizados os tratamentos.

\subsection{Curva de seleção por puromicina}

Para determinar a concentração ótima para utilizar na seleção positiva após a transfecção, foi feito o ensaio de curva de seleção. Foram semeadas $5.10^{4}$ células $/ \mathrm{mL}$ da linhagem A549, em placa de 12 poços. Depois de $24 \mathrm{~h}$ de adesão, foram tratadas com diversas concentrações de puromicina (Sigma) $(0,25 \mu \mathrm{g} / \mathrm{mL}, 0,5 \mu \mathrm{g} / \mathrm{mL}, 1,0 \mu \mathrm{g} / \mathrm{mL}, 2,0 \mu \mathrm{g} / \mathrm{mL}, 4,0 \mu \mathrm{g} / \mathrm{mL}$ e $8,0 \mu \mathrm{g} / \mathrm{mL})$. As células foram acompanhadas por 10 dias, trocando o meio com a concentração respectiva de puromicina a cada $48 \mathrm{~h}$. 


\subsection{CRISPR: plasmídeos utilizados}

Todos os plasmídeos utilizados são pSpCas9 BB-2A-PURO (PX459) com $9174 \mathrm{pb}$ e foram comprados da GenScript USA Inc (Piscataway, NJ, EUA). Os plasmídeos codificam a enzima Cas9 com o RNA guia para o silenciamento dos genes humanos: ATG5, ATG7, Beclin 1 ou CHOP. Todos possuiam o gene de resistência à puromicina, a qual foi utilizada durante a seleção positiva das células transfectadas. Foram escolhidas duas sequências para cada gene, para assegurar 0 silencimento, sendo as sequências dos plasmídeos 1 , as indicadas com maior chance de sucesso pelo fabricante.

As sequências guias da Cas9 dos plasmídeos para os respectivos genes são:

ATG5:

Pasmídeo 1: AACTTGTTTCACGCTATATC

Pasmídeo 2: TTCCATGAGTTTCCGATTGA

ATG7:

Pasmídeo 1: AGAAGAAGCTGAACGAGTAT

Pasmídeo 2: CTTGAAAGACTCGAGTGTGT

Beclin 1:

Pasmídeo 1: ATTTATTGAAACTCCTCGCC

Pasmídeo 2: ATCTGCGAGAGACACCATCC CHOP:

Pasmídeo 1: CCGAGCTCTGATTGACCGAA

Pasmídeo 2: AGGAAATCGAGCGCCTGACC 


\subsection{Preparo de bactérias competentes}

Para o preparo de bactérias E.coli DH5a e TOP10 competentes, foi feito um pré-inóculo com uma colônia de cada cepa em $5 \mathrm{~mL}$ de meio LB (Luria-Bertani: Tabela 1) sob agitação $10 \mathrm{~g}$ a $37{ }^{\circ} \mathrm{C}$ overnight. $100 \mu \mathrm{L}$ do pré-inóculo foram cultivados em $10 \mathrm{~mL}$ de $\mathrm{LB}$ até atingir a fase exponencial $\left(\mathrm{OD}_{600}=0,3-0,4\right) .1$ $\mathrm{mL}$ da cultura foi aliquotada em microtubos, centrifugada por $5 \mathrm{~min}, 300 \mathrm{~g} 4{ }^{\circ} \mathrm{C}$. O sobrenadante foi descartado e o pellet ressuspendido e congelado a $-80^{\circ} \mathrm{C}$ em $100 \mu \mathrm{L}$ 1xTSS (do inglês: Transformation and Storage Solution, Tabela 2)

Tabela 1. Composição do meio de cultura LB

Meio Luria Bertani (LB) por litro
$10 \mathrm{~g}$ Triptona
$5 \mathrm{~g}$ Extrato de levedura
$5 \mathrm{~g}$ de NaCl
$\mathrm{NaOH}$ (até $\mathrm{pH} 8)$
$15 \mathrm{~g}$ agar (para meio semi-sólido em placa)

FONTE: Ausubel FM, et al. Short protocols in molecular biology. EUA. John Wiley \& Sons. 2002. (62)

Tabela 2. Composição da solução 2xTSS

\begin{tabular}{c} 
2xTSS \\
$10 \%$ LB \\
$20 \%$ PEG 3350 a 8000 \\
$10 \%$ DMSO \\
$100 \mathrm{mM} \mathrm{MgCl}_{2}$ \\
$\mathrm{pH} 6,5$ \\
\hline
\end{tabular}

FONTE: Ausubel FM, et al. Short protocols in molecular biology. EUA. John Wiley \& Sons. 2002. (62) 


\subsection{Transformação de bactérias TOP10 e DH5a com plasmídeos de CRISPR e plaqueamento}

Os plasmídeos pSpCas9 BB-2ª-PURO PX459 (Genescript) contendo os genes de Beclin 1, ATG 5, ATG7 e CHOP, sendo duas construções para cada gene, estavam liofilizados e foram ressuspensos em água ultra-pura, mantendo uma concentração de $0,2 \mu \mathrm{g} / \mu \mathrm{L}$. Para a obtenção de maior quantidade desses plasmídeos, as bactérias E.coli DH5a e TOP10 competentes criopreservadas a $-80^{\circ} \mathrm{C}$, foram descongeladas sob o gelo e incubadas, por $30 \mathrm{~min}$ sob o gelo, com 100ng de cada plasmídeo contendo o gene de resistência à ampicilina. Em seguida, foi adicionado meio SOC (Tabela 3) e as bactérias foram mantidas na incubadora a $37^{\circ} \mathrm{C}$ e sob agitação. Após $1,5 \mathrm{~h}$ de incubação, as bactérias foram semeadas em uma placa de LB-ágar sem ampicilina (para controle da viabilidade das bactérias) e uma placa de LB-ágar com ampicilina $100 \mu \mathrm{g} / \mathrm{mL}$. Estas placas foram incubadas a $37^{\circ} \mathrm{C}$ overnight e, as colônias isoladas na placa LB-ágar com ampicilina de bactérias transformadas foram selecionadas, com o auxílio de uma ponteira e ampliadas em meio LB com ampicilina.

Tabela 3. Composição do meio de cultura SOC

\begin{tabular}{c}
\hline Meio SOC \\
\hline $0,5 \%$ Extrato de Levedura \\
$2 \%$ Triptona \\
$10 \mathrm{mM} \mathrm{NaCl}$ \\
$2,5 \mathrm{mM} \mathrm{KCl}^{10 \mathrm{mM} \mathrm{MgCl}_{2}}$ \\
$10 \mathrm{mM} \mathrm{MgSO}_{4}$ \\
$20 \mathrm{mM} \mathrm{Glicose}^{2}$
\end{tabular}

FONTE: Ausubel FM, et al. Short protocols in molecular biology. EUA. John Wiley \& Sons. 2002. (62) 


\subsection{Extração e purificação dos plasmídeos por mini-preparação (MiniPrep)}

Para a extração e purificação dos plasmídeos da bactéria foi realizado o protocolo de miniprep, utilizando o kit GeneJetPlasmidMiniPrep (Thermo Fisher Scientific, Pierce, IL, EUA). No dia anterior foi feito um pré-inóculo de bactérias contendo os plasmídeos com os genes Beclin 1, ATG 5, ATG7 e CHOP. Uma colônia isolada de cada placa foi colocada em $5 \mathrm{~mL}$ de meio LB (Tabela 2) com ampicilina $(100 \mu \mathrm{g} / \mathrm{mL})$ em tubos de polipropileno e ficaram sob agitação de 250 rpm overnight a $37^{\circ} \mathrm{C}$. Desse pré-inóculo, $1 \mathrm{~mL}$ foi colocado em $10 \mathrm{~mL}$ de LB com ampicilina $(100 \mu \mathrm{g} / \mathrm{mL})$ em erlenmeyer e ficaram sob agitação de 250rpm overnight a $37^{\circ} \mathrm{C}$.

No dia seguinte o caldo da cultura bacteriana foi dividido e transferido para tubos de $15 \mathrm{~mL}$ e centrifugados a $2500 \mathrm{G}$ durante $10 \mathrm{~min}$ e o sobrenadante foi descartado. Foi adicionado ao pellet formado $250 \mu \mathrm{L}$ de solução de ressuspensão e foi homegenizado vigorosamente em vortex para ressuspensão total do pellet celular. Acrescentou-se $250 \mu \mathrm{L}$ da solução de lise seguido de homogeneização cuidadosa por inversão dos tubos de $4-6$ vezes até a solução ter ficado viscosa e ligeiramente clara. Em seguida foi adicionado $350 \mu \mathrm{L}$ da solução de neutralização e novamente foi feita homogeneização cuidadosa por inversão de $4-6$ vezes. Os tubos foram centrifugados a 2500G por $15 \mathrm{~min}$.

Para purificar o DNA de interesse, o sobrenadante da etapa anterior foi colocado em micro-coluna de sílica acoplada a um tubo de microcentrífuga do kit, e o material foi centrifugado a 12000rpm por 1 min e o material não retido na coluna foi descartado. Foram adicionados $500 \mu \mathrm{L}$ da solução de lavagem ao DNA retido na coluna e centrifugado por 1 min a 12000 rpm. O material não retido na coluna foi descartado e o procedimento foi repetido. Foi feito uma nova centrifugação a $12000 \mathrm{rpm}$ por $1 \mathrm{~min}$ para remover qualquer resíduo da solução de lavagem.

Para a eluição do plasmídeo da coluna, esta foi transferida para um novo tubo de $1,5 \mathrm{~mL}$ estéril e identificado, e adicionou-se $50 \mu \mathrm{L}$ do tampão de eluição. 
Os tubos ficaram incubando por 2 min a temperatura ambiente e então foram centrifugados por 2 min a 12000rpm. Em seguida, os tubos de DNA eluído foram armazenados a $-20^{\circ} \mathrm{C}$.

\subsection{Padronização da técnica de transfecção celular por eletroporação}

A padronização da técnica de transfecção celular por eletroporação dos plasmídeos pSpCas9 utilizando o 4D-Nucleofector system-Core unit/X unit (Lonza) para as linhagens celulares A549 e H460, foi iniciada testando as soluções de transfecção SF e SE do kit Cell Line Optimization 4DNucleofector ${ }^{\circledR}$ X e 0 4D- Nucleofector ${ }^{\circledR}$ (Lonza, Alemanha) e os diferentes pulsos configurados no equipamento. Foram separadas $10^{5}$ células/amostra em tubos de $1,5 \mathrm{~mL}$ e centrifugadas a 100G. De cada tubo o sobrenadante foi retirado e acrescentado o mix de transfecção contendo $16,4 \mu \mathrm{L}$ da solução de transfecção, 3,6 $\mu \mathrm{L}$ de suplemento 1 do kit e $20 \mathrm{ng} / \mu \mathrm{L}$ de plasmídeo contendo o gene repórter GFPmax. As amostras foram transferidas para a cubeta e transfectadas no aparelho. Após $10 \mathrm{~min}$ em repouso, foi acrescentado $100 \mu \mathrm{L}$ de meio RPMI a $37^{\circ} \mathrm{C}$ em cada cubeta e transferido $40 \mu \mathrm{L} /$ poço em placa de 24 poços, completando o volume para $500 \mu \mathrm{L}$ com meio RPMI. Foi mantido em cultura e analisado em colaboração com o Prof. Dr. Jean Pierre Schatzmann Peron no aparelho ZOE Fluorescent Cell Imager (Bio-Rad).

\subsection{Transfecção celular por eletroporação}

As células A549 foram transfectadas utilizando o kit Cell Line Optimization 4DNucleofector $\AA^{\circledR}$ X e o 4D- Nucleofector ${ }^{\circledR}$ (Lonza, Alemanha), de acordo com as instruções do fabricante, utilizando a solução SF e os pulsos EN138 e EH100. O plasmídeo pGFPmax (pmax GFP ${ }^{T M}$, Lonza, Alemanha) (1ug) foi incluído para monitorar a eficiência de transfecção. A eficiência da tranfecção foi analisada através da porcentagem de células positivas para GFP por microscopia de fluorescência, usando o microscópio ZOE (Biorad, CA, EUA). 
Enquanto aos outros plasmídeos, foram selecionadas por puromicina após 48h à transfecção.

\subsection{Transfecção celular por lipofectamina}

As células A549 foram semeadas ( $2.10^{5}$ células) em meio sem soro e antibióticos e transfectadas com o complexo com lipofectamina 3000 (Life Tecnologies, EUA) e 500ng dos plasmídeos. A placa foi incubada por $4 \mathrm{~h}$ e em seguida cada poço foi suplementado com soro fetal bovino. Após $48 \mathrm{~h}$ da transfecção as células foram selecionadas por puromicina.

\subsection{Curva de seleção por puromicina}

Para determinar a concentração ótima para utilizar na seleção positiva após a transfecção, foi feito o ensaio de curva de seleção. Foram semeadas $5.10^{4}$ células $/ \mathrm{mL}$ da linhagem A549, em placa de 12 poços. Depois de $24 \mathrm{~h}$ de adesão, foram tratadas com diversas concentrações de puromicina (Sigma) $(8 \mu \mathrm{M}, 4 \mu \mathrm{M}, 2 \mu \mathrm{M}, 1 \mu \mathrm{M}, 0,5 \mu \mathrm{M}$ e $0,25 \mu \mathrm{M})$. As células foram acompanhadas de 7 a 10 dias, trocando o meio com a concentração respectiva de puromicina a cada $48 \mathrm{~h}$.

\subsection{Western Blotting}

A técnica de Western Blotting foi utilizada para avaliar os níveis de expressão de proteínas relacionadas à autofagia e estresse de retículo endoplasmático nas linhagens ( $\mathrm{A} 549$ e $\mathrm{NCl}-\mathrm{H} 460$ ) e para garantir que houve o silenciamento dos genes relacionados à autofagia nas células A549 transfectadas. As células de linhagem tumoral foram semeadas $\left(10^{6}\right.$ células em garrafa de $25 \mathrm{~cm}^{2}$ ), pré-tratadas com os inibidores de autofagia (controle 
positivo) bafilomicina $(1 \mu \mathrm{M})$ ou cloroquina $(50 \mu \mathrm{M})$, e tratadas com $\mathrm{CHY}-1$ $(5 \mu \mathrm{M})$, cisplatina (10 ou $40 \mu \mathrm{M})$ ou SF2 (10 ou $20 \mu \mathrm{M})$. Após os tratamentos, as células foram lisadas com o reagente de extração de proteínas de mamíferos (Mammalian Protein Extraction Reagent $\AA$, Thermo Scientific Pierce, IL, EUA) contendo $10 \%$ de inibidor de protease e de inibidor de fosfatase.

Os lisados celulares foram diluídos em tampão Standard Western blotting (50mM Tris- $\mathrm{HCl}, \mathrm{pH} 6,8$, SDS (dodecil sulfato de sódio) a 2\%, glicerol 10\%, 5\% de $2-\beta$ mercaptoetanol, $0,002 \%$ azul de bromofenol) e desnaturados por aquecimento. Em seguida, os lisados celulares foram fracionados por eletroforese (SDS-PAGE (do inglês: PolyAcrylamide Gel Electrophoresis), Biorad, CA, EUA) e transferidos para membranas de fluoreto de polivinilideno (PVDF). Após a transferência, as membranas foram lavadas em tampão de Tris-salino com Tween-20 (TTBS: $100 \mathrm{mM}$ Tris- $\mathrm{HCl}, 137 \mathrm{mM}$ de $\mathrm{NaCl}$ e $0,05 \%$ de Tween-20, $\mathrm{pH} 7,8$ ) e bloqueadas durante $1 \mathrm{~h}$ em albumina de soro bovino (BSA, do inglês: Bovine Serum Albumin) 5\% diluído em TTBS. Após outra lavagem com TTBS, a membrana foi incubada overnight com os anticorpos primários a $4^{\circ} \mathrm{C}$. A membrana foi novamente lavada com TTBS e, então, incubada por $1 \mathrm{~h}$ com anticorpo secundário conjugado a horseradish peroxidase. A detecção foi realizada com o kit de Pierce® Western Blotting Substrate Plus (Thermo Fisher Scientific Pierce, IL, EUA) e a densidade de pixels das bandas quantificadas a fim de comparar as alterações de expressão proteica.

\subsection{Microscopia Eletrônica de Transmissão (MET)}

O preparado das amostras, fixação, inclusão, cortes semi-finos e ultra-finos das células A549, foi feito em colaboração com o laboratório de microscopia eletrônica da Profa. Dra. Élia Tamaso Espin Garcia Caldini, da FM-USP. E as imagens foram feitas, utilizando o microscópio eletrônico de transmissão (MET), em colaboração com o Setor de Microscopia Eletrônica do Departamento de Biologia Celular e do Desenvolvimento ICB-USP. 


\subsection{Análise estatística dos resultados}

Todas as análises estatísticas foram realizadas usando o software GraphPadPrism, versão 7 (LaJolla, San Diego, CA, USA). Os valores foram expressos em média \pm desvio padrão de três experimentos independentes realizados em triplicata. Para o cálculo estatístico dos ensaios de citotoxicidade, a análise foi realizada por ANOVA seguido de teste comparativo múltiplo de Bonferroni, considerando valores significantes ${ }^{*} \mathrm{p}<0.05$, ${ }^{* *} \mathrm{p}<0.01 \mathrm{e}$ ${ }^{* * *} p<0.001$. 
4.1 Avaliação dos efeitos citotóxicos dos quimioterápicos cisplatina, paclitaxel e o do anticorpo monoclonal bevacizumab nas células de CPCNP

Inicialmente foram realizados os estudos de citotoxicidade dos compostos cisplatina, paclitaxel e bevacizumab nas células de CPCNP A549, NCl-H1299, $\mathrm{NCl}-\mathrm{H} 292$ e NCl-H460, para determinar os valores de $\mathrm{IC}_{50}$. Nesse protocolo, foi possível apenas calcular os valores de $\mathrm{IC}_{50}$ para a cisplatina, pois mesmo com altas concentrações de paclitaxel $(160 \mu \mathrm{M})$ e bevacizumab $(80 \mu \mathrm{g} / \mathrm{mL})$ não foram capazes de reduzir em $50 \%$ a viabilidade das células testadas em $24 \mathrm{~h}$. Os respectivos valores de $\mathrm{IC}_{50}$ estão na Tabela 4 abaixo:

Tabela 4. Valores de $\mathrm{IC}_{50}$

\begin{tabular}{rcccc}
\hline & \multicolumn{4}{c}{ IC $_{50 \pm} \pm$ DP } \\
\hline Tratamentos & A549 & NCl-H1299 & NCl-H292 & NCl-H460 \\
Cisplatina $(\mu \mathrm{M})$ & $106 \pm 4$ & $>160$ & $>160$ & $65 \pm 11$ \\
Paclitaxel $(\mu \mathrm{M})$ & $>160$ & $>160$ & $>160$ & $>160$ \\
Bevacizumab $(\mu \mathrm{g} / \mathrm{mL})$ & $>80$ & $>80$ & $>80$ & $>80$ \\
\hline
\end{tabular}

FONTE:Dados da autora

\subsection{Determinação da eficácia da combinação terapêutica do CHY-1 com os agentes utilizados na primeira linha de tratamento de CPCNP}

Os tratamentos foram realizados utilizando uma única concentração subcitotóxica dos valores obtidos dos ensaios de citotoxicidade. Em estudos anteriores do grupo, o valor de $\mathrm{IC}_{50}$ de $\mathrm{CHY}-1$ encontrado foi de $8 \mu \mathrm{M}$ (dados não publicados), assim a dose sub-citotóxica utilizada foi de $5 \mu \mathrm{M}$. Para o anticorpo monoclonal bevacizumab foi utilizado $10 \mu \mathrm{g} / \mathrm{mL}$ e para cisplatina e paclitaxel, $40 \mu \mathrm{M}$. 
As células A549, $\mathrm{NCl}-\mathrm{H} 1299, \mathrm{NCl}-\mathrm{H} 292$ e NCl-H460 foram tratadas durante $24 \mathrm{~h}$ com os seguintes esquemas de tratamento: i) CHY-1 $(5 \mu \mathrm{M})+$ bevacizumab $(10 \mu \mathrm{g} / \mathrm{mL})$. ii) CHY-1 $(5 \mu \mathrm{M})+$ cisplatina $(40 \mu \mathrm{M})$. iii) CHY-1 (5 $\mu \mathrm{M})+$ paclitaxel $(40 \mu \mathrm{M})$. Os resultados obtidos após $24 \mathrm{~h}$ de tratamento mostraram que a combinação de $\mathrm{CHY}-1$ com bevacizumab resultou efeitos sinérgicos apenas para a linhagem $\mathrm{NCl}-\mathrm{H} 460$. A combinação entre $\mathrm{CHY}-1$ e cisplatina foi sinérgica para todas as linhagens testadas e a combinação de CHY-1 e paclitaxel, apenas para NCl-H1299 e NCl-H460 (Figura 1).
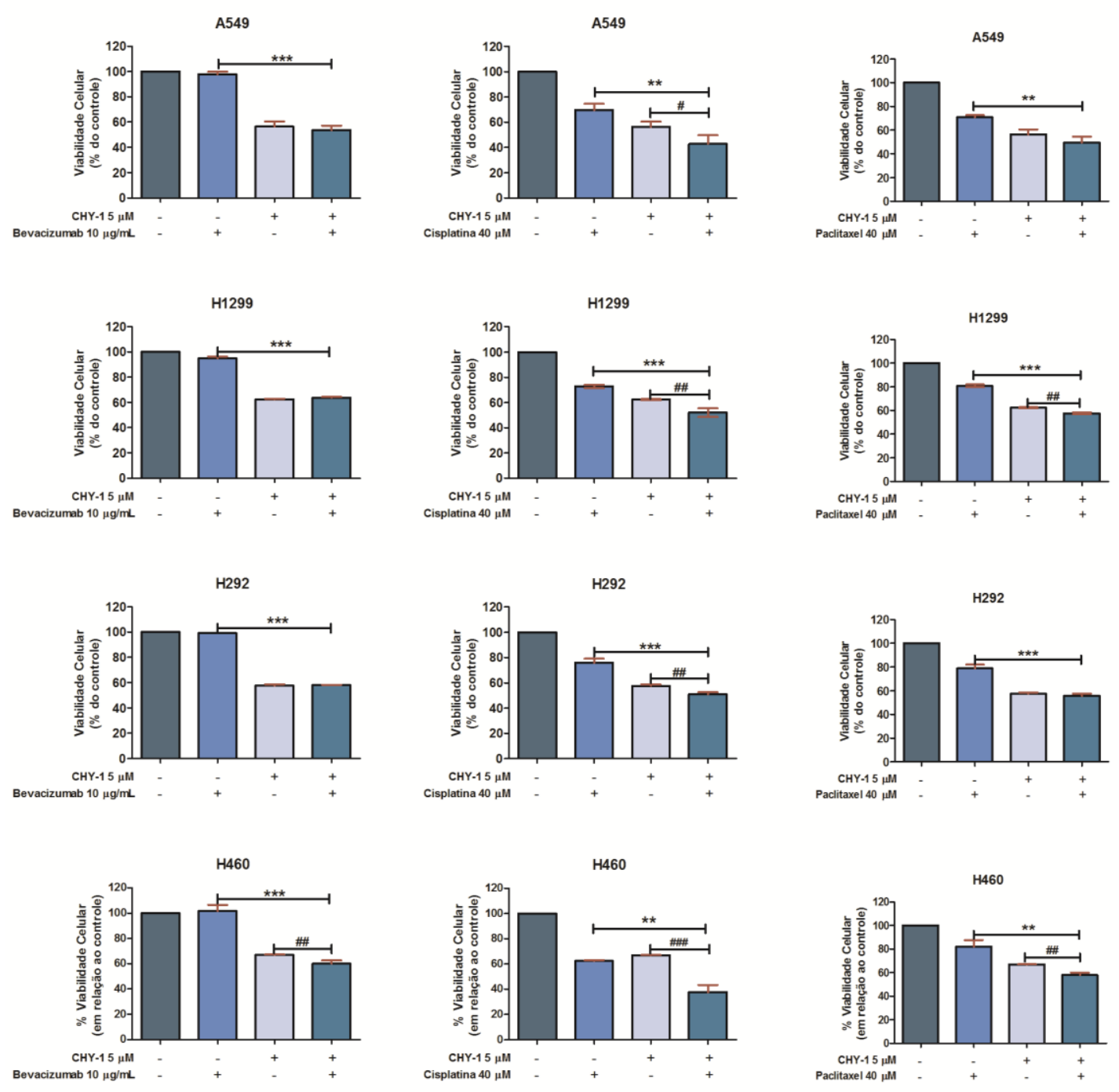

FONTE: Dados da autora.

Figura 1. Os efeitos da combinação de CHY-1 com bevacizumab, cisplatina e paclitaxel sobre a viabilidade celular de CPCNP. Foram semeadas $10^{4}$ células/poço e tratadas com os compostos durante $24 \mathrm{~h}$. A viabilidade celular foi avaliada pelo método MTT e é expressa como a porcentagem de células em relação ao controle. Esta avaliação foi realizada nas linhagens celulares de CPCNP A549, NCl-H1299, NCl-H292 e NCl-H460. Onde: * ou \# $\mathrm{p}<0.05$, ** ou \#\# $p<0.01 e^{* * *}$ ou \#\#\# $p<0.001$; relações indicadas pela linha sobre as colunas. 


\subsection{Avaliação das proteínas envolvidas no processo autofágico e estresse de retículo endoplasmático}

Em estudos prévios do grupo, foi demonstrado que o CHY-1, na concentração de $I_{50}$, é capaz de induzir estresse de RE pela ativação das proteínas do sistema UPR (do inglês: unfolded protein response). Desta forma, as células $\mathrm{NCl}-\mathrm{H} 460$ e A549 foram tratadas por $24 \mathrm{~h}$ com concentrações subcitotóxicas do CHY-1 e cisplatina, e o sistema UPR foi monitorado por Western Blotting. O tratamento com CHY-1 aumentou a expressão das proteínas que compõem o sistema UPR: PERK (do inglês: protein kinase RNA-like endoplasmic reticulum kinase) e IRE1a (do inglês: inositol-requiring enzyme 1 a) (Figuras 2 e 3). Este aumento indica que o CHY-1 induziu o acúmulo de proteínas desdobradas interrompendo assim, a homeostase do RE (63). Para as concentrações utilizadas dos tratamentos em A549, não foi possível observar variação da expressão, em relação ao controle, da chaperona GRP94 (do inglês: 94 kDa glucose-regulated protein), nem da proteína ERp44 (do inglês: Endoplasmic reticulum resident protein 44), ambas são induzidas quando há estresse do RE na tentativa de regular a translocação retrógrada das proteínas danificadas destinadas a degradação pelo sistema proteassomal, para $\mathrm{NCl}-\mathrm{H} 460$ houve o aumento de ERp44 (64). Como resultante dessas ativações, houve aumento da expressão de CHOP, fator de transcrição conhecido como principal mediador da apoptose estimulada pela ativação da UPR (65).

Para avaliar se as concentrações sub-citotóxicas de CHY-1 e da cisplatina interferem na biogénese dos autofagossomos, investigou-se a família de proteínas relacionadas com a autofagia, as ATGs. A análise por Western Blotting mostrou que o tratamento de $\mathrm{CHY}-1$ com cisplatina reduz os sistemas de conjugação ATG5 e ATG7 e beclin-1 nas células NCl-H460 e A549 (Figuras 2 e 3). Desta forma, a inibição de PE por CHY-1 perturbou o processo de formação fagófaro, prejudicando a formação da estrutura de membrana, impedindo a expansão do fagófaro para formar o autofagolissosomo. 


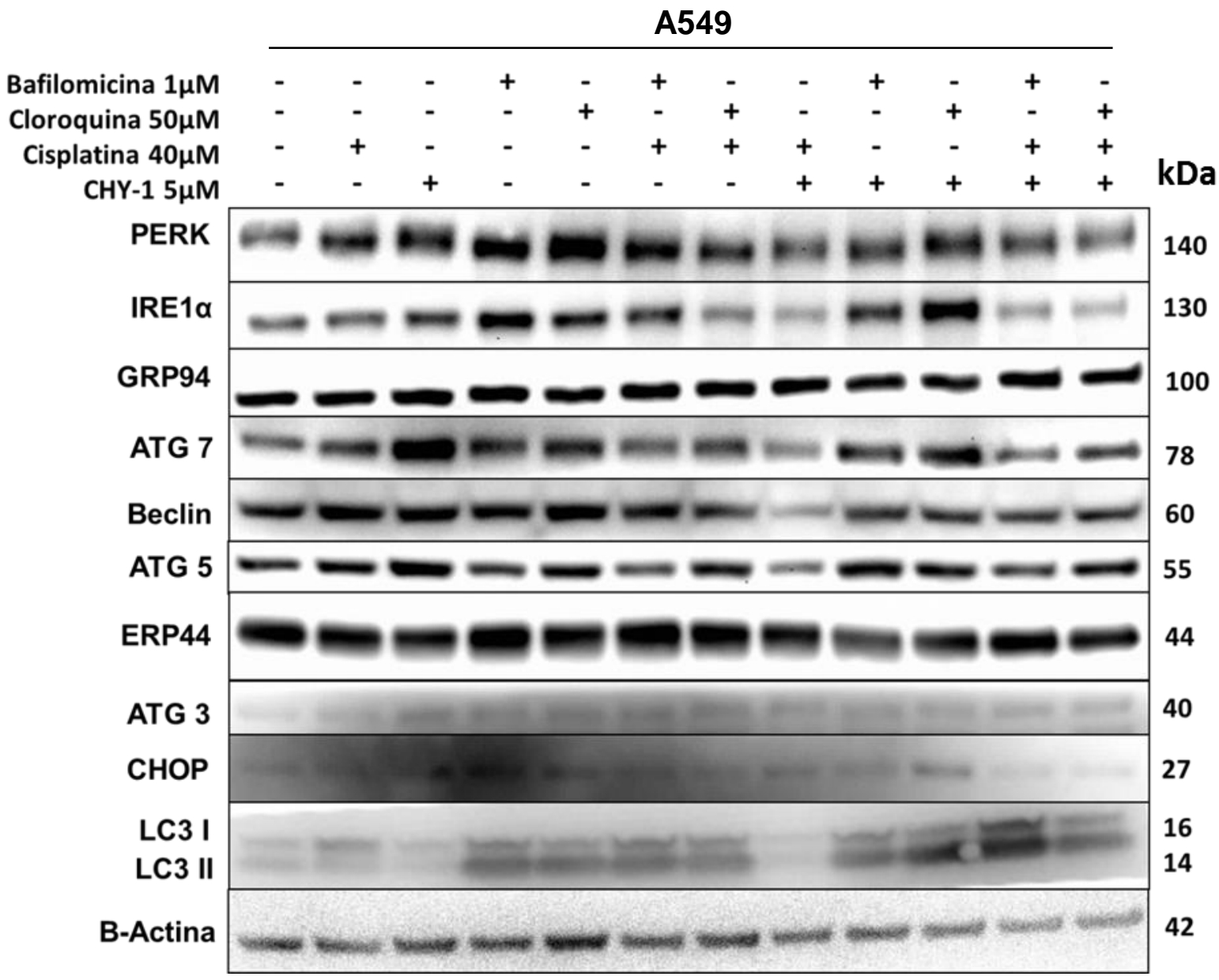

FONTE: Dados da autora.

Figura 2. Análise das proteínas relacionadas ao estresse de retículo endoplasmático e autofagia em A549. Imagem representativa dos resultados da detecção das proteínas de estresse de retículo endoplasmático e de autofagia por Western Blotting das células A549, prétratadas por $1 \mathrm{~h}$ com bafilomicina $\mathrm{A}_{1}(1 \mu \mathrm{M})$ ou cloroquina $(50 \mu \mathrm{M})$, e tratadas com CHY-1 (5 $\mu \mathrm{M})$ e/ou cisplatina $(40 \mu \mathrm{M})$ 


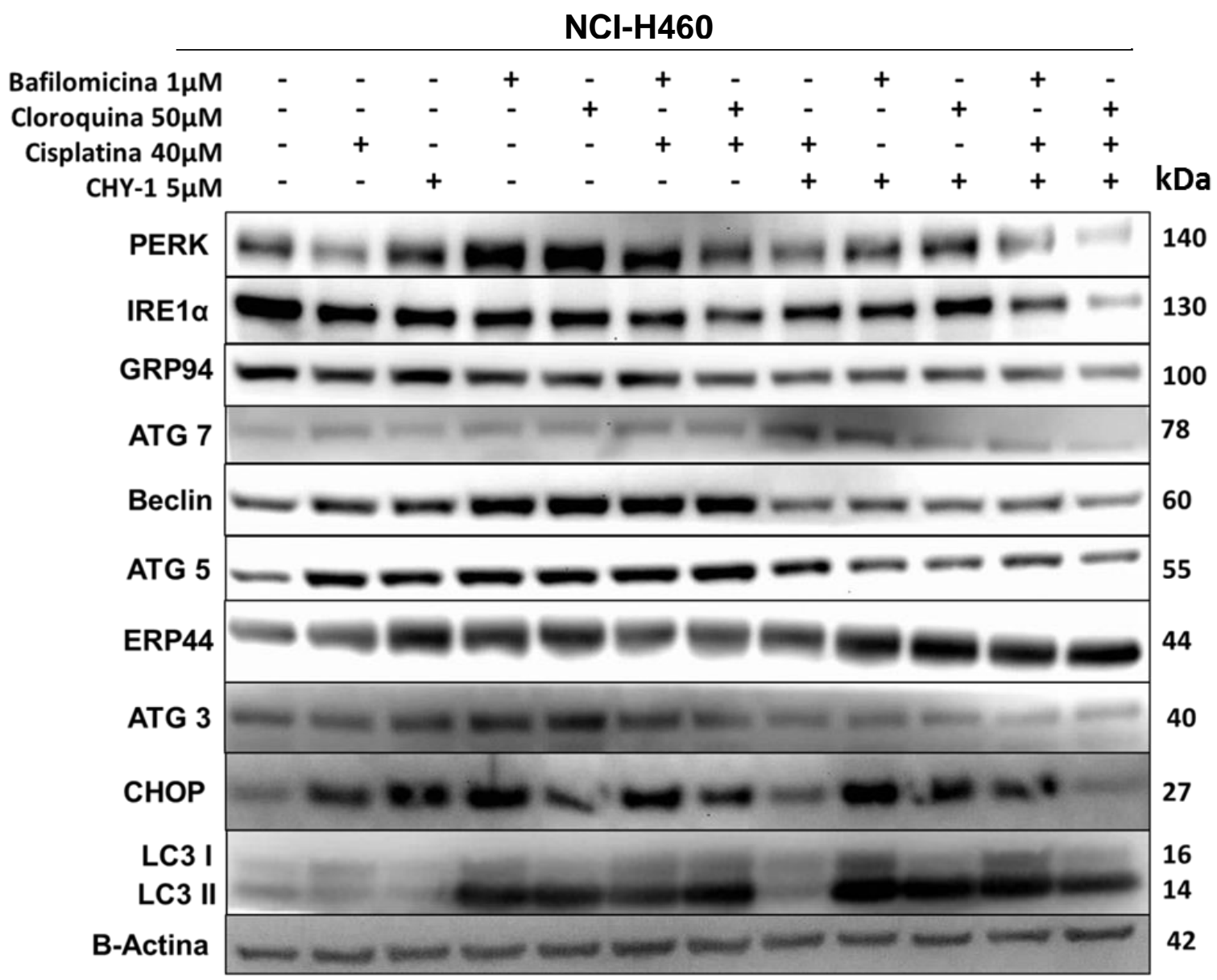

Figura 3. Análise das proteínas relacionadas ao estresse de retículo endoplasmático e autofagia em $\mathbf{N C l}-\mathbf{H} 460$. Imagens representativas das membranas de Western Blotting da avaliação da expressão das proteínas de estresse de retículo endoplasmático e de autofagia por das células $\mathrm{NCl}-\mathrm{H} 460$, pré-tratadas por $1 \mathrm{~h}$ com bafilomicina $\mathrm{A}_{1}(1 \mu \mathrm{M})$ ou cloroquina (50 $\mu \mathrm{M})$, e tratadas com CHY-1 (5 $\mu \mathrm{M})$ e/ou cisplatina $(40 \mu \mathrm{M})$. 


\subsection{Avaliação dos efeitos citotóxicos do composto SF2, um intermediário da rota sintética de obtenção do CHY-1}

Inicialmente foram realizadas triagens da atividade citotóxica de SF2 nas linhagens humanas A549 e NCl-H460, e na murina LL2, e em uma linhagem celular de fibroblasto pulmonar humana (MRC-5) através do ensaio de MTT. A partir das densidades ópticas, foram calculadas as porcentagens de viabilidade celular em relação ao controle e as curvas dose-resposta do composto para cada linhagem $A$ partir destas curvas, foram calculados os valores de $I_{50}$, sendo os valores obtidos encontram-se na tabela 5 abaixo:

Tabela 5. Valores de IC50 $(\mu \mathrm{M})$ de SF2

\begin{tabular}{|ccccccc}
\hline & & \multicolumn{4}{c}{ IC $_{50}(\mu \mathrm{M}) \pm$ DP } \\
Tratamento & & A549 & H460 & LL2 & MRC-5 \\
& SF2 & $41 \pm 12$ & $89 \pm 14$ & $32 \pm 8$ & $130 \pm 53$ \\
\hline
\end{tabular}

FONTE: Dados da autora. 


\subsection{Avaliação dos efeitos de SF2 na enzima Pcyt-2}

Em colaboração com a Dra Marica Bokovic, da Universidade de Guelph, Canadá, foi realizado o teste de inibição da enzima Pcyt-2 por SF2. Foi comprovado que o SF2 não somente é capaz de inibir a ação da enzima Pcyt2 isolada (Tabela 6), como também de reduzir o transporte de etanolamina intracelular (Tabela 7). A meclizina a $50 \mu \mathrm{M}$, utilizada como controle positivo reduziu para $37 \%$ da atividade da enzima, enquanto que o SF2 a $60 \mu \mathrm{M}$ reduziu para $35 \%$. Tais resultados são extremamente promissores considerando-se que a miltefosina, o principal protótipo da classe dos fosfolipídios antineoplásicos, não é capaz de inibir a atividade enzimática da Pcyt-2, nem os níveis da PEtn intracelular.

Tabela 6. Valores de teste da atividade da enzima Pcyt2 isolada

\begin{tabular}{lr}
\hline \multicolumn{1}{c}{ Tratamentos } & \% CTRL \\
\hline Controle (sem tratamento) & 100 \\
Meclizina $(50 \mu \mathrm{M})$ & 37,2 \\
SF2 $(60 \mu \mathrm{M})$ & 35,3 \\
\hline FONTE: Dados da autora.
\end{tabular}

Tabela 7. Valores representativos da produção de etanolamina e CDP-Etn quando células MCH58 foram tratadas com meclizina e SF2

\begin{tabular}{lrr}
\hline \multicolumn{1}{c}{ Tratamentos } & Etanolamina & CDP-Etn \\
\hline Controle (sem tratamento) & 29,59 & 11,62 \\
Meclizina $(25 \mu \mathrm{M})$ & 6,3 & 5,1 \\
SF2 $(25 \mu \mathrm{M})$ & 9,19 & 8,34 \\
\hline & &
\end{tabular}

FONTE: Dados da autora. 


\subsection{Avaliação dos mecanismos de morte celular por SF2}

Com a finalidade de estudar os mecanismos de morte celular, comparar os resultados obtidos dos tratamentos de cisplatina (Cis) e SF2, além de suas combinações, foi realizado o ensaio de anexina V/PI (Figuras 4 e 5). Como controle positivo de morte celular, foi utilizado o TRAIL (do inglês: Tumor necrosis factor (TNF)-related apoptosis-inducing ligand), entretanto a linhagem A549 é resistente para este indutor de apoptose. Como é possível observar, o aumento da porcentagem de células apoptóticas é dose dependente para SF2, porém por este ensaio, não foi possível observar uma diferença entre os tratamentos isolados e com os combinados. Além disso, SF2 $80 \mu \mathrm{M}$ sozinho foi mais citotóxico do que em combinação com a cisplatina, sugerindo que SF2 não esteja atuando apenas na autofagia.

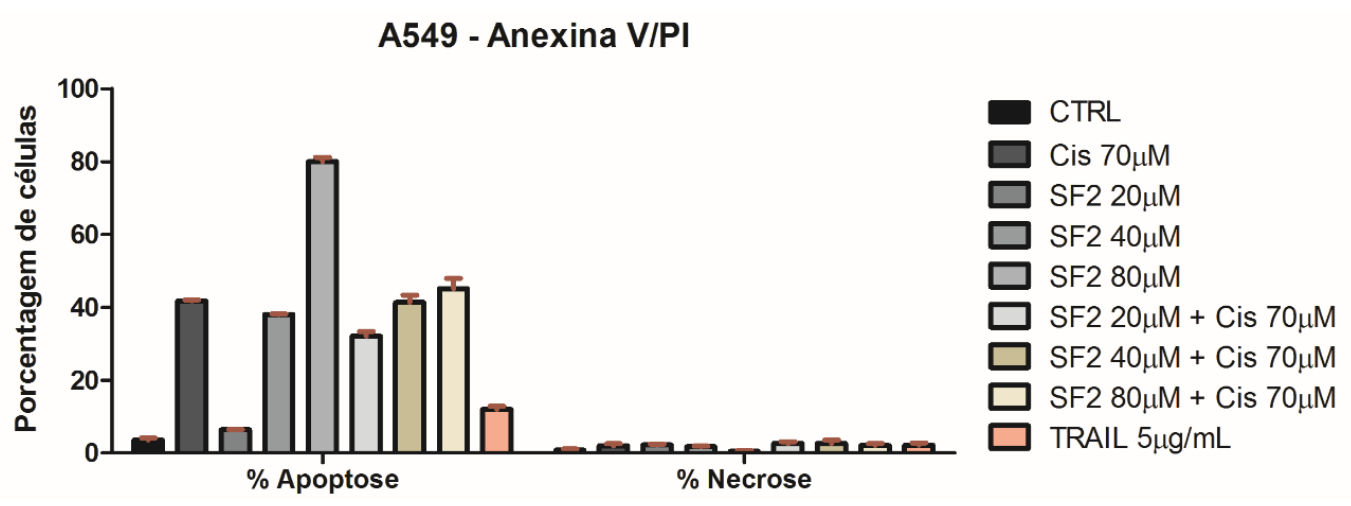

FONTE: Dados da autora.

Figura 4. Ensaio de anexina V/PI em células A549. Porcentagem de células em apoptose ou necrose.

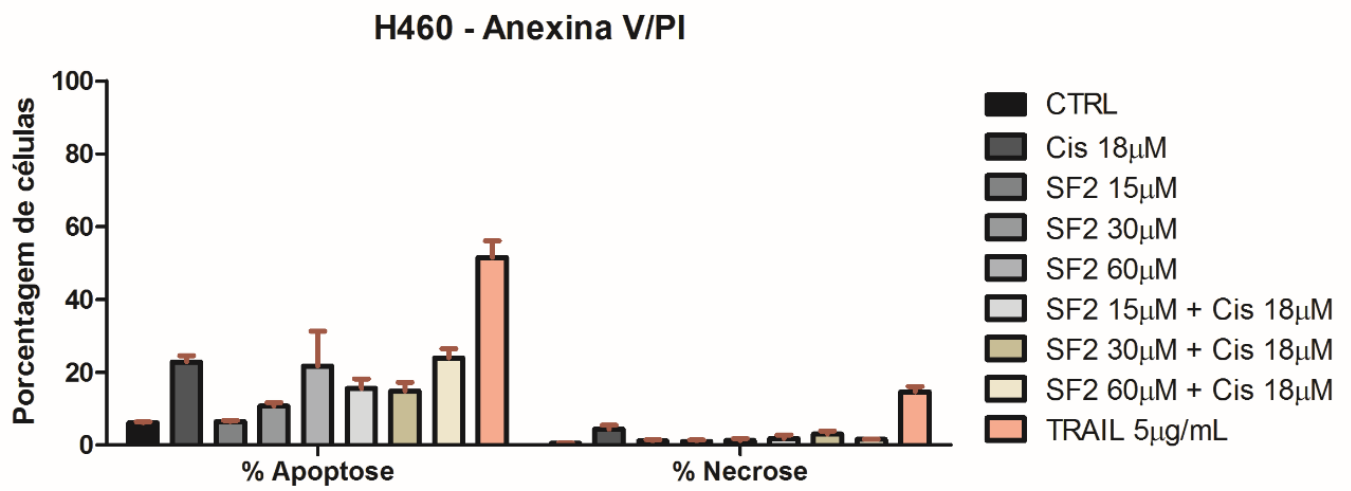

FONTE: Dados da autora.

Figura 5. Ensaio de anexina V/PI em células H460. Porcentagem de células em apoptose ou necrose.. 


\subsection{Avaliação do potencial de membrana mitocondrial}

Neste experimento, foram comparados os resultados obtidos dos tratamentos de cisplatina (Cis) e SF2, além de suas combinações (Figuras 6 e 7). O CCCP, um desacoplador da membrana interna da mitocôndria, foi utilizado como controle positivo, pois suprime o potencial eletroquímico mitocondrial, causando a despolarização da membrana. O SF2 foi capaz de reduzir o potencial elétrico da membrana mitocondrial das células A549 e NClH460. Deste modo, SF2 induziu a morte celular e danos mitocondriais das células A549 e NCl-H460, ou seja, leva as células à apoptose com participação mitocondrial, corroborando os dados anteriores de com a marcação dupla com anexina/PI. 


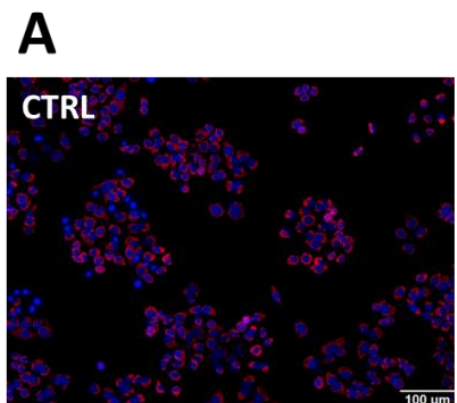

\section{A549 - TMRE}
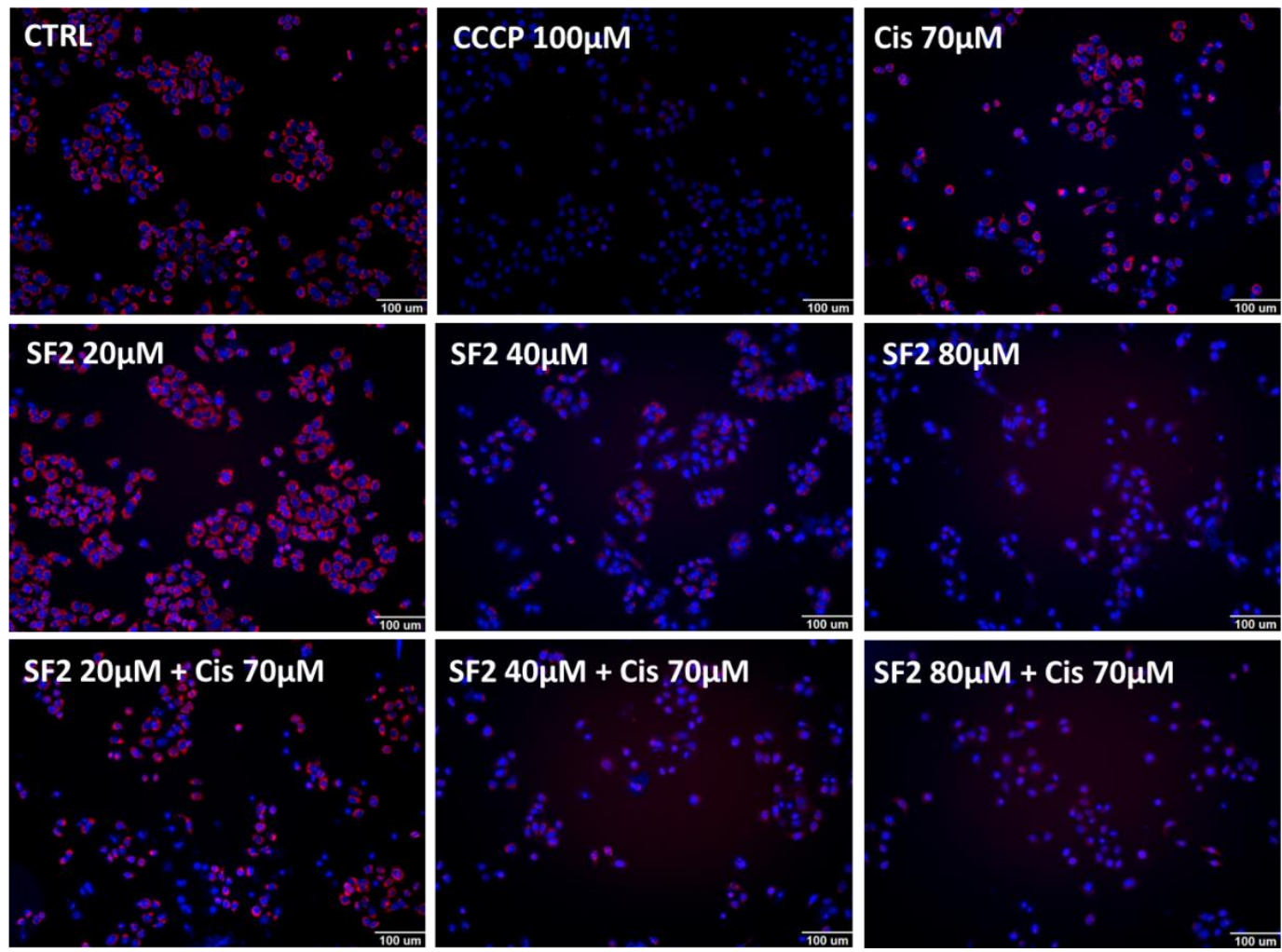

\section{SF2 80 $\mu \mathrm{M}$}

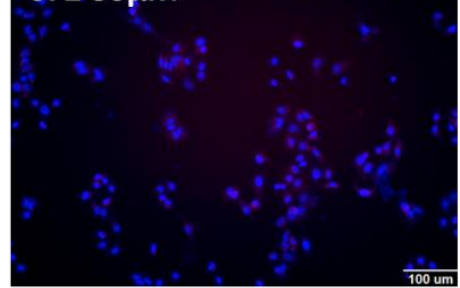

SF2 $80 \mu \mathrm{M}+$ Cis $70 \mu \mathrm{M}$

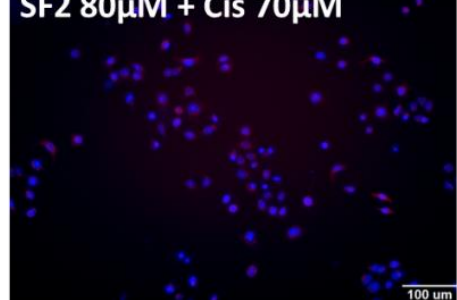

B

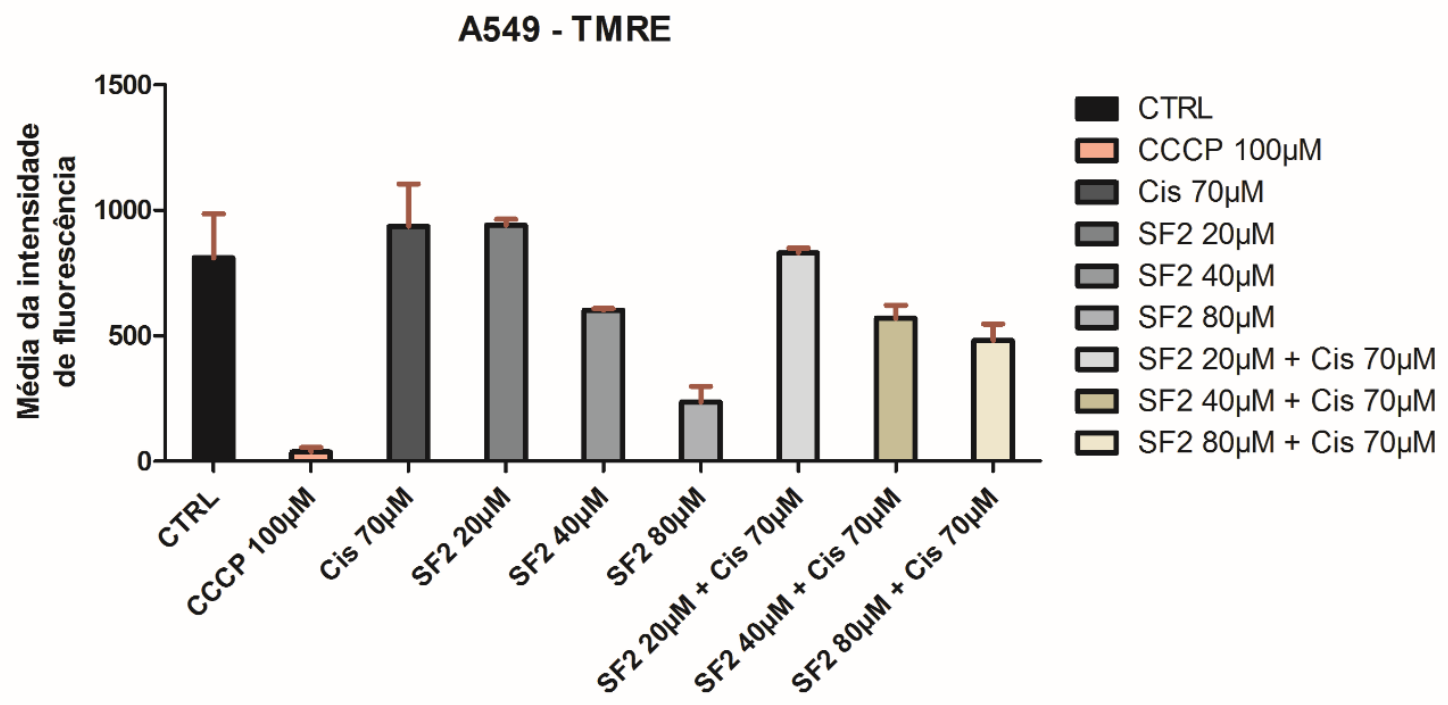

FONTE: Dados da autora.

Figura 6. Alteração do potencial de membrana mitocondrial para A549. A) Análise da alteração do potencial de membrana mitocondrial pela sonda TMRE (vermelho), escala: $100 \mu \mathrm{m}$. B) Quantificação da média da intensidade de fluorescência. 
A
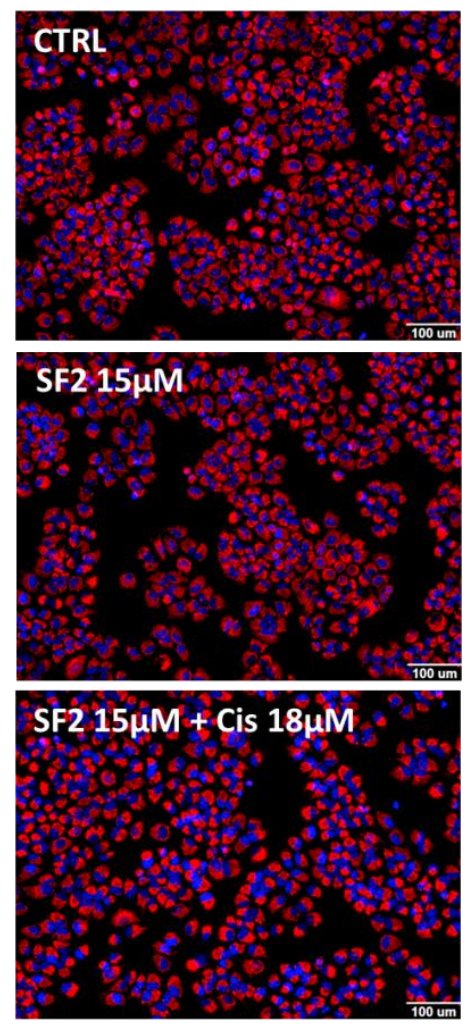

\section{H460 - TMRE}

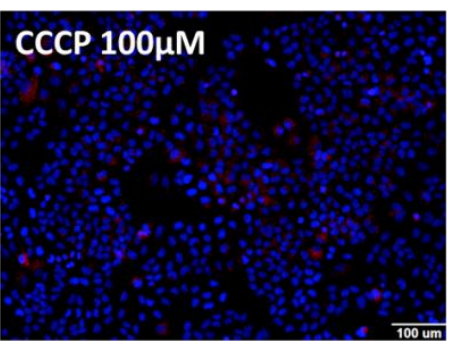

SF2 30 $\mathrm{MM}$

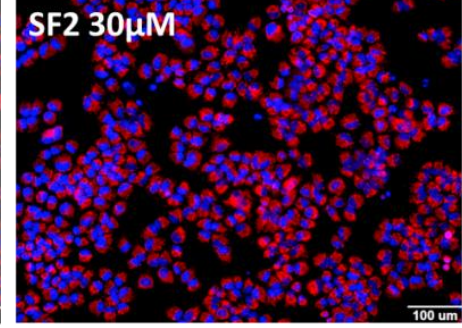

SF2 $30 \mu \mathrm{M}+$ Cis $18 \mu \mathrm{M}$

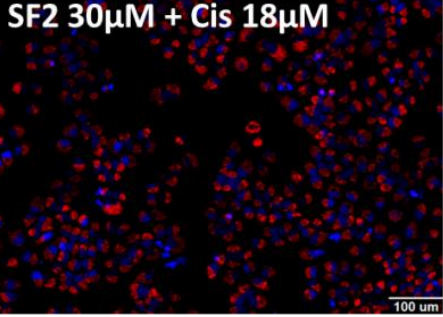

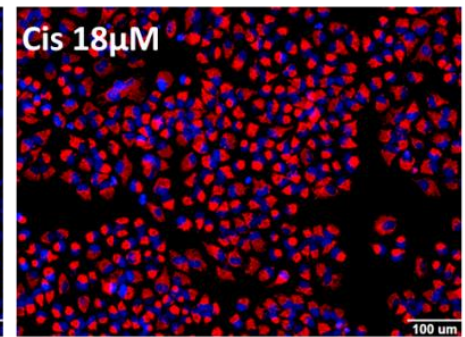

SF2 60 $\mathrm{MM}$

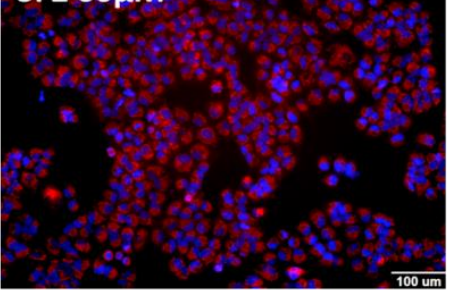

SF2 $60 \mu \mathrm{M}+$ Cis $18 \mu \mathrm{M}$

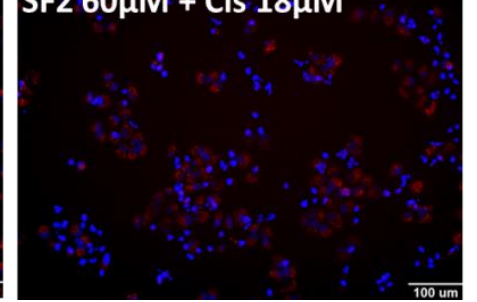

\section{B}

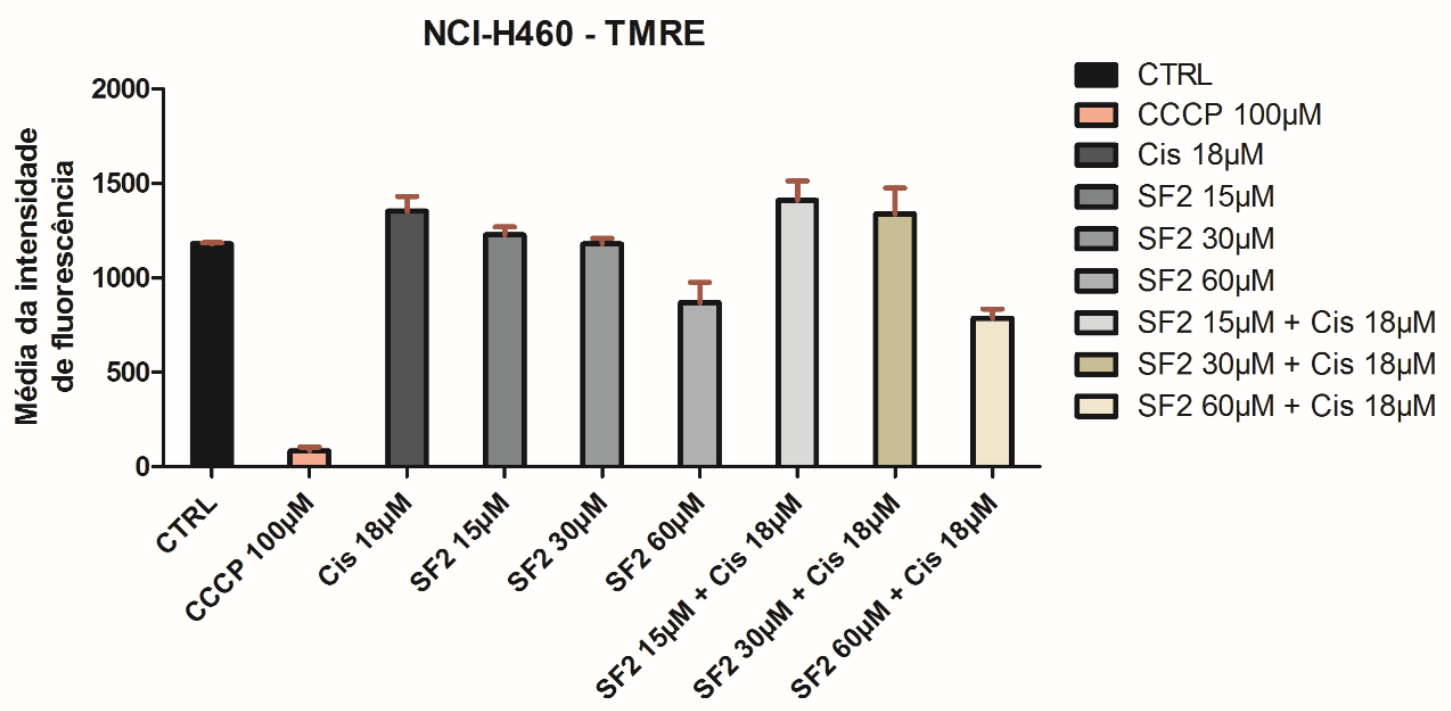

FONTE: Dados da autora.

Figura 7. Alteração do potencial de membrana mitocondrial para H460. A) Análise da alteração do potencial de membrana mitocondrial pela sonda TMRE (vermelho), escala: $100 \mu \mathrm{m}$. B) Quantificação da média da intensidade de fluorescência. 


\subsection{Transformação de bactérias competentes com plasmídeos de CRISPR}

Foi feito o preparo de bactérias competentes pelo método 1xTSS, para que nestas pudessem ser inseridos os plasmídeos de CRISPR. Para avaliar se a introdução do plasmídeo havia sido efetiva, a seleção foi feita por ampicilina, uma vez que se encontra o gene de resistência a esse antibiótico nos plasmídeos. Como esperado, com o mesmo volume de cultura aplicado em placas LB-ágar, sem ampicilina, houve um crescimento exagerado sem formação de colônia (Figura 8A), enquanto que com ampicilina, houve seleção pela formação de colônias isoladas (Figura 8B). Em seguida, foi feito o protocolo de miniprep para a extração e purificação dos plasmídeos, partindo de uma das colônias que foram isoladas na placa. A quantidade de plasmídeo obtida foi quantificada utilizando um espectrofotômetro do tipo Nanodrop, sendo os valores obtidos para cada construção de: Beclin-1: $13 \mathrm{ng} / \mathrm{mL}$ e 17 ng/mL; ATG5: 73 ng/mL e 15 ng/mL; ATG7: 124 ng/mL e 12 ng/mL; CHOP: 10 $\mathrm{ng} / \mathrm{mL}$ e $17 \mathrm{ng} / \mathrm{mL}$.
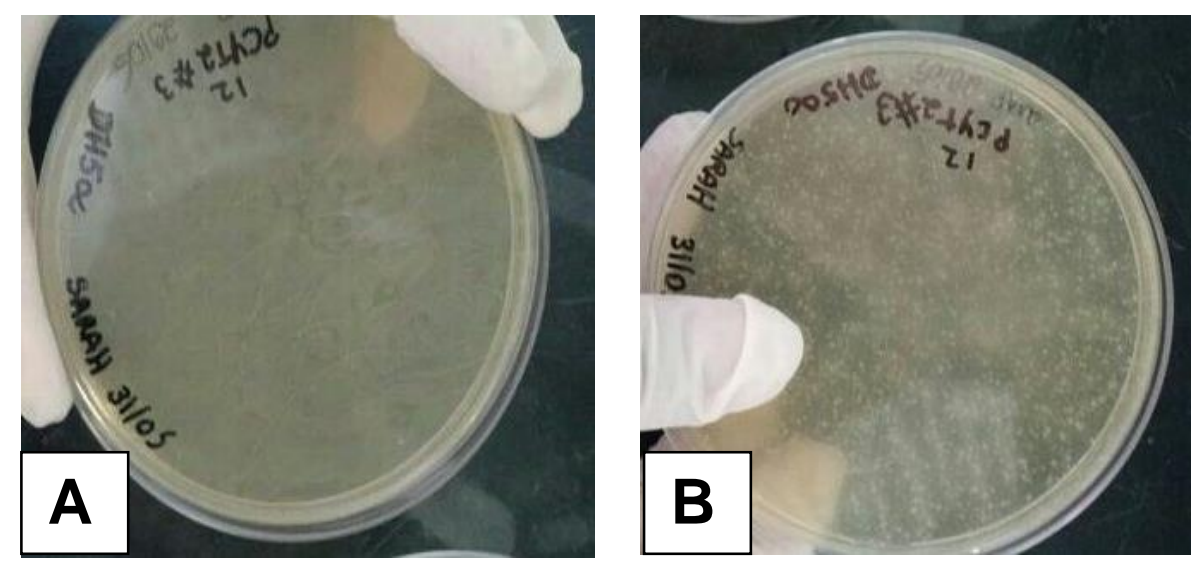

FONTE: Dados da autora.

Figura 8. Crescimento bacteriano em placa LB-ágar. A) Sem formação de colônias isoladas em plaqueamento de $100 \mu \mathrm{L}$ de cultura de bactéria após transformação com plasmídeo em placa LB-ágar sem ampicilina. B) Formação de colônias isoladas em plaqueamento de $100 \mu \mathrm{L}$ de cultura de bactéria após transformação com plasmídeo em placa LB-ágar com ampicilina. 


\subsection{Determinação da concentração de puromicina para seleção de células transfectadas}

Os plasmídeos adquiridos possuem o gene de seleção por puromicina. Para determinar a concentração ótima para selecionar as células transfectadas, foi feito uma curva de seleção durante10 dias nas células A549 não transfectadas. No $7^{0}$ dia foi observado que da concentração $1 \mu \mathrm{g} / \mathrm{mL}$ para cima, todas as células do poço já estavam mortas (Figura 9). No 10 dia, todas as células do poço com a concentração $0,5 \mu \mathrm{g} / \mathrm{mL}$ estavam mortas, enquanto que dos de $0,25 \mu \mathrm{g} / \mathrm{mL}$ e controle estavam vivas. Por isso, a concentração determinada para a seleção de células transfectadas foi de $1 \mu \mathrm{g} / \mathrm{mL}$ de puromicina.

\section{A549 - Curva de seleção por puromicina}
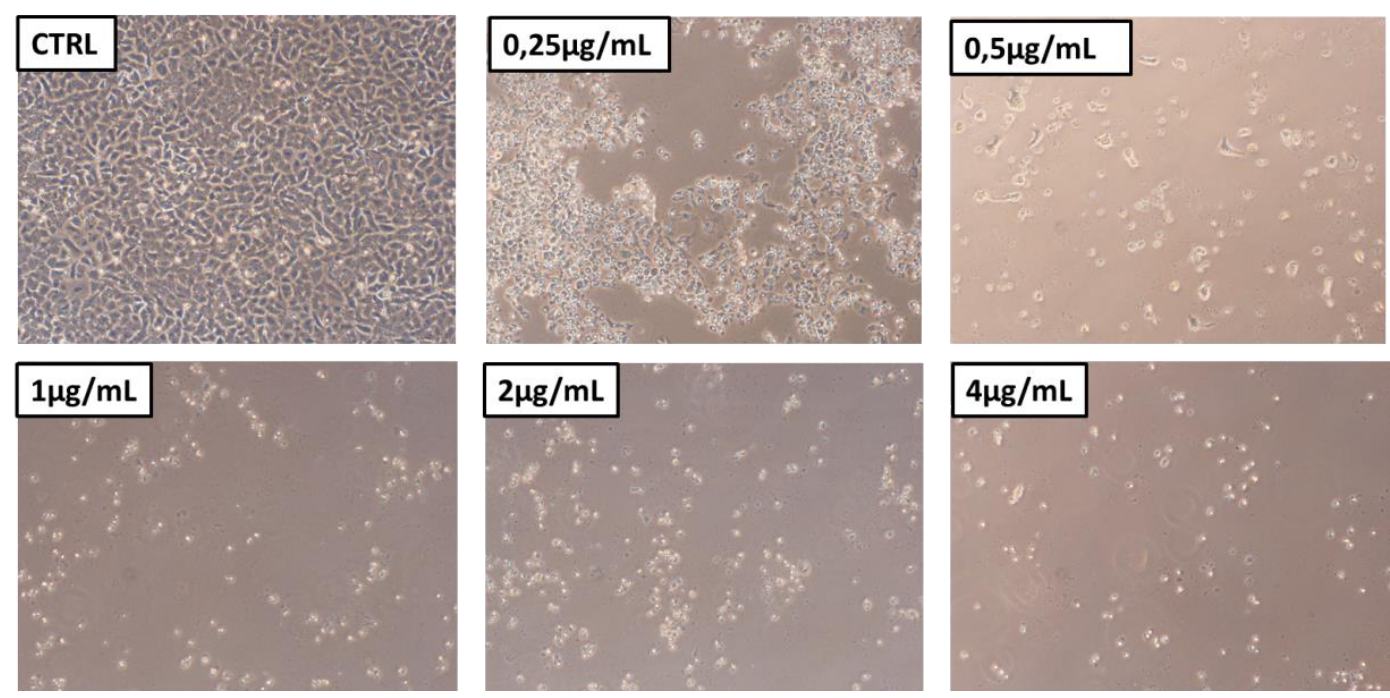

FONTE: Dados da autora.

Figura 9. Curva de seleção por puromicina. Células A549 semeadas em placa de 12 poços $\left(0,5.10^{5}\right.$ célula/poço), objetiva no aumento de $4 \mathrm{x}$. Curva no $7^{\circ}$ dia feita para determinar a concentração ótima para selecionar células transfectadas com plasmídeo contendo gene resistente à puromicina. A concentração determinada foi de $1 \mu \mathrm{g} / \mathrm{mL}$. 


\subsection{Padronização da técnica de transfecção celular por eletroporação}

Após amplificação dos plasmídeos em bactérias competentes DH5-a, iniciamos a padronização da técnica de CRISPR/Cas9. A padronização da técnica de transfecção celular por eletroporação foi feita utilizando o 4DNucleofector system-Core unit/X unit (Lonza) para as linhagens celulares A549 e H460, testando as soluções de transfecção SF e SE do kit Cell Line Optimization 4DNucleofector ${ }^{\circledR}$ X e o 4D-Nucleofector ${ }^{\circledR}$ (Lonza, Alemanha) e os diferentes pulsos configurados no equipamento. Foram separadas $10^{5}$ células/amostra em tubos de $1,5 \mathrm{~mL}$ e centrifugadas a $100 \mathrm{~g}$. De cada tubo 0 sobrenadante foi retirado e acrescentado o mix de transfecção contendo 16,4 $\mu \mathrm{L}$ da solução de transfecção, 3,6 $\mu \mathrm{L}$ de suplemento 1 do kit e $20 \mathrm{ng} / \mu \mathrm{L}$ de plasmídeo contendo o gene repórter GFPmax. As amostras foram transferidas para a cubeta e transfectadas no aparelho. Após $10 \mathrm{~min}$ em repouso, foi acrescentado $100 \mu \mathrm{L}$ de meio RPMI a $37^{\circ} \mathrm{C}$ em cada cubeta e transferido 40 $\mu \mathrm{L} /$ poço em placa de 24 poços, completando o volume para $500 \mu \mathrm{L}$ com meio RPMI. Foi mantido em cultura e analisado em colaboração com o Prof. Dr. Jean Pierre Schatzmann Peron no aparelho ZOE Fluorescent Cell Imager (BioRad).

Foi iniciada a padronização testando a solução de transfecção e o pulso sugeridos no database da empresa (SF CM130) para a célula A549. Segundo informações do fabricante, esta combinação teria eficiência de transfecção de $80 \%$ e taxa de viabilidade celular de $60 \%$ para esta linhagem celular. Esta combinação foi testada utilizando o plasmídeo contendo somente o gene repórter GFP (pGFPmax). Porém, como é possível observar na Figura 10, a transfecção não foi eficiente, mesmo em diferentes concentrações de plasmídeo. Portanto foram testados outros 14 pulsos com a solução SF (Figura 11) e também com a SE com 13 pulsos (Figura 12). 


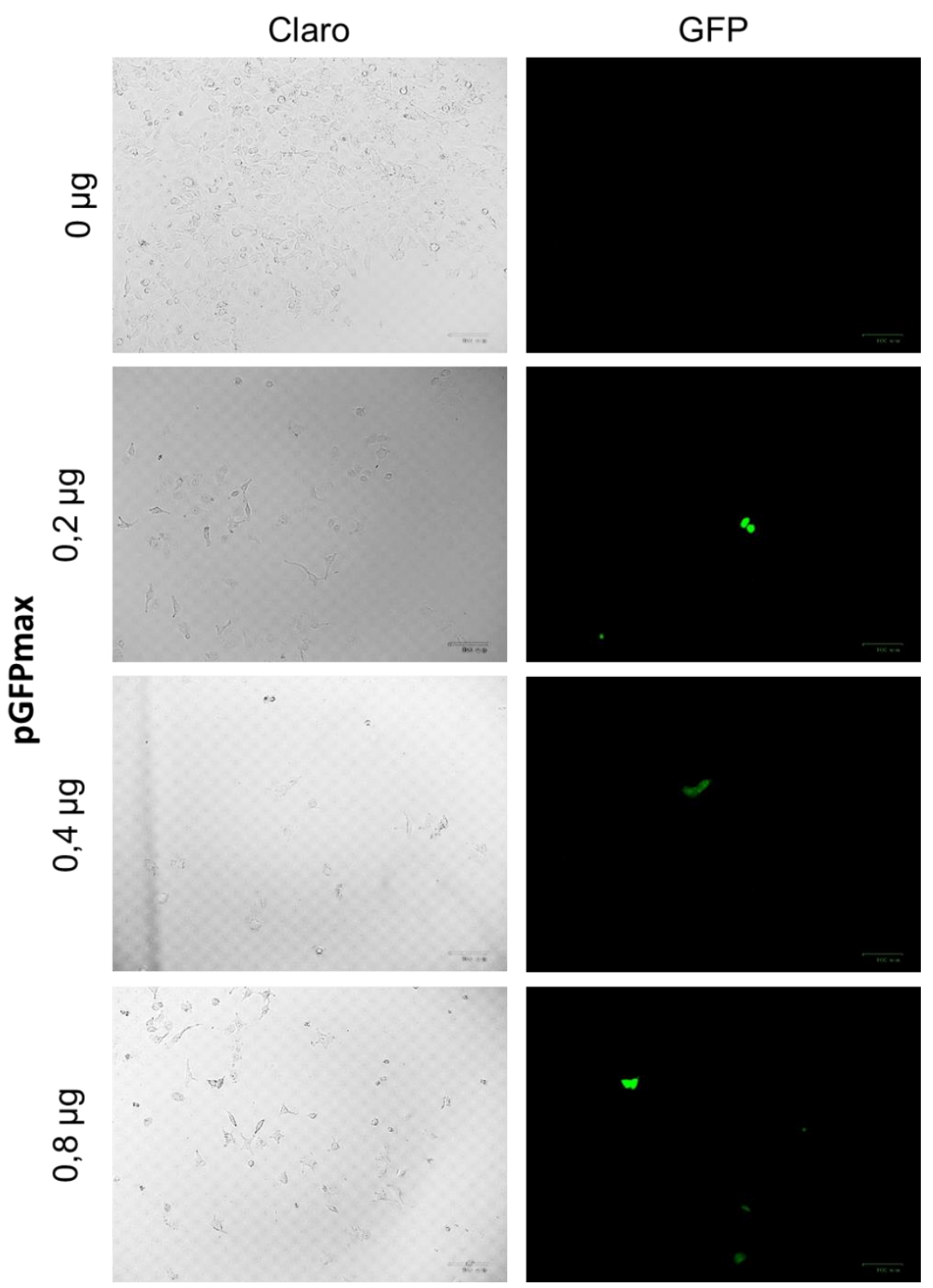

FONTE: Dados da autora.

Figura 10. Transfecção de células A549 com pGFPmax. Ensaio utilizando a solução e o pulso sugerido pelo fabricante para a transfecção de células A549 com o gene repórter GFP, em três concentrações diferentes. 


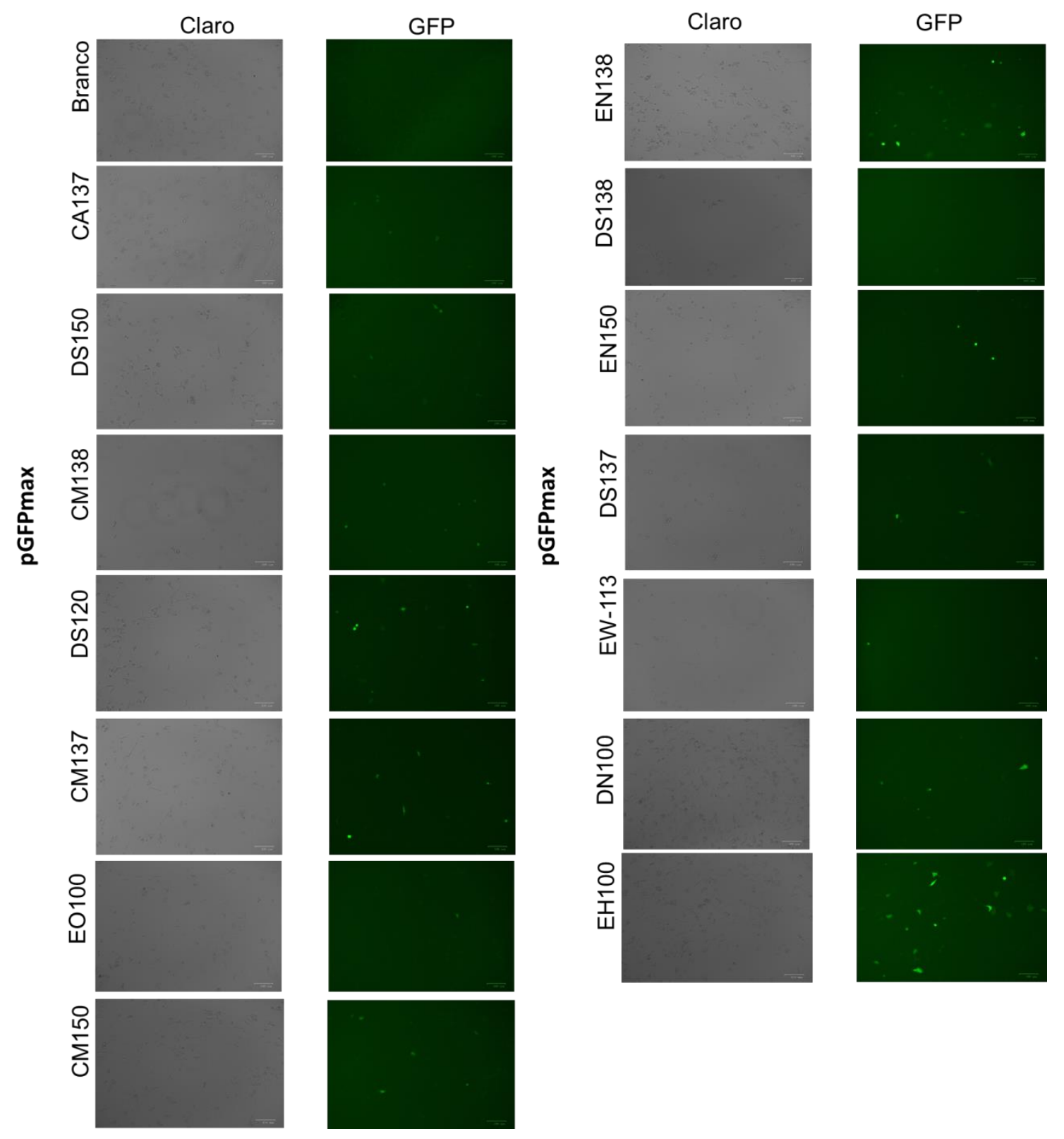

FONTE: Dados da autora.

Figura 11. Padronização da técnica CRISPR/Cas9 na linhagem de células A549 utilizando o gene repórter GFP com a solução SF. Teste de 14 pulsos padronizados no equipamento $4 D$-Nucleofector system-Core unit/X unit (Lonza). 

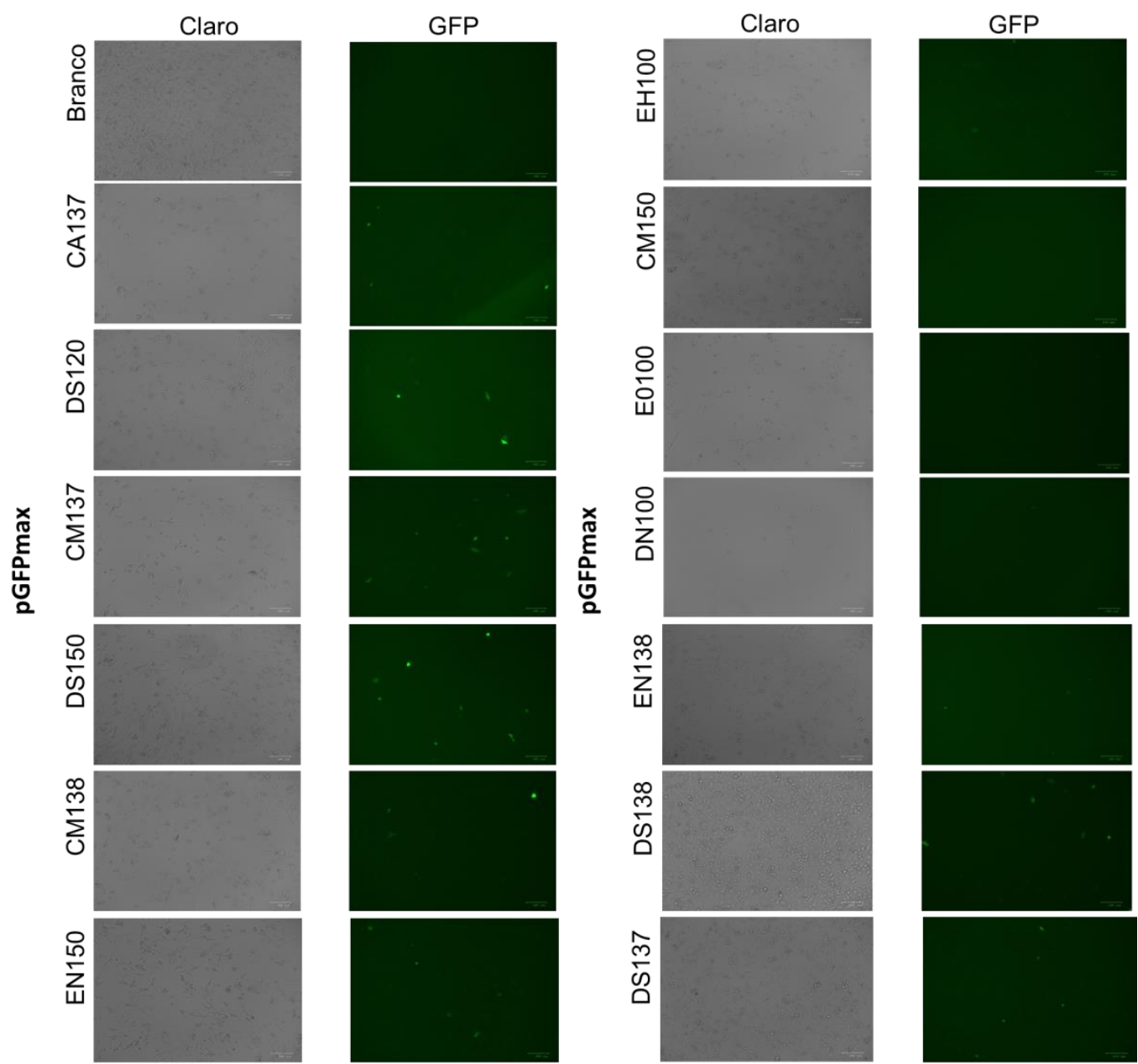

FONTE: Dados da autora.

Figura 12. Padronização da técnica CRISPR/Cas9 na linhagem de células A549 utilizando o gene repórter GFP com a solução SE. Teste de 13 pulsos padronizados no equipamento $4 D$-Nucleofector system-Core unit/X unit (Lonza).

Como esperado, no controle (branco) contendo somente o mix de solução e suplemento, não foi possível identificar nenhuma célula marcada em verde (Figuras 11 e 12). Em todos os demais pulsos testados pudemos observar células marcadas, porém em diferentes proporções. Embora os ensaios tiveram uma boa eficiência, optou-se pelos pulsos EN138 e EH100 da solução SF para seguir com o protocolo de transfecção. Para a linhagem NCl-H460 não foram obtidas células $\mathrm{GFP}^{+}$apesar de diversas tentativas de padronizar uma técnica mais eficiente de transfecção, portanto seguimos os experimentos apenas com a linhagem A549. 


\subsection{Transfecção celular por eletroporação}

As células A549 foram transfectadas com os plasmídeos para 0 silenciamento dos genes: ATG5, ATG7, Beclin-1 ou CHOP, sendo dois plasmídeos para cada gene, variando a sequência, utilizando o kit Cell Line Optimization 4DNucleofector $\AA$ X e o 4D- Nucleofector ${ }^{\circledR}$ (Lonza, Alemanha), de acordo com as instruções do fabricante, utilizando a solução SF e os pulsos EN138 e EH100. O plasmídeo pGFPmax (pmax GFP ${ }^{T M}$, Lonza, Alemanha) (1 ug) foi incluído para monitorar a eficiência de transfecção (Figura 13). A eficiência da tranfecção foi analisada através da porcentagem de células positivas para GFP por microscopia de fluorescência, usando o microscópio ZOE (Biorad, CA, EUA). Enquanto aos outros plasmídeos, as células silenciadas foram selecionadas por puromicina após $48 \mathrm{~h}$ a transfecção.

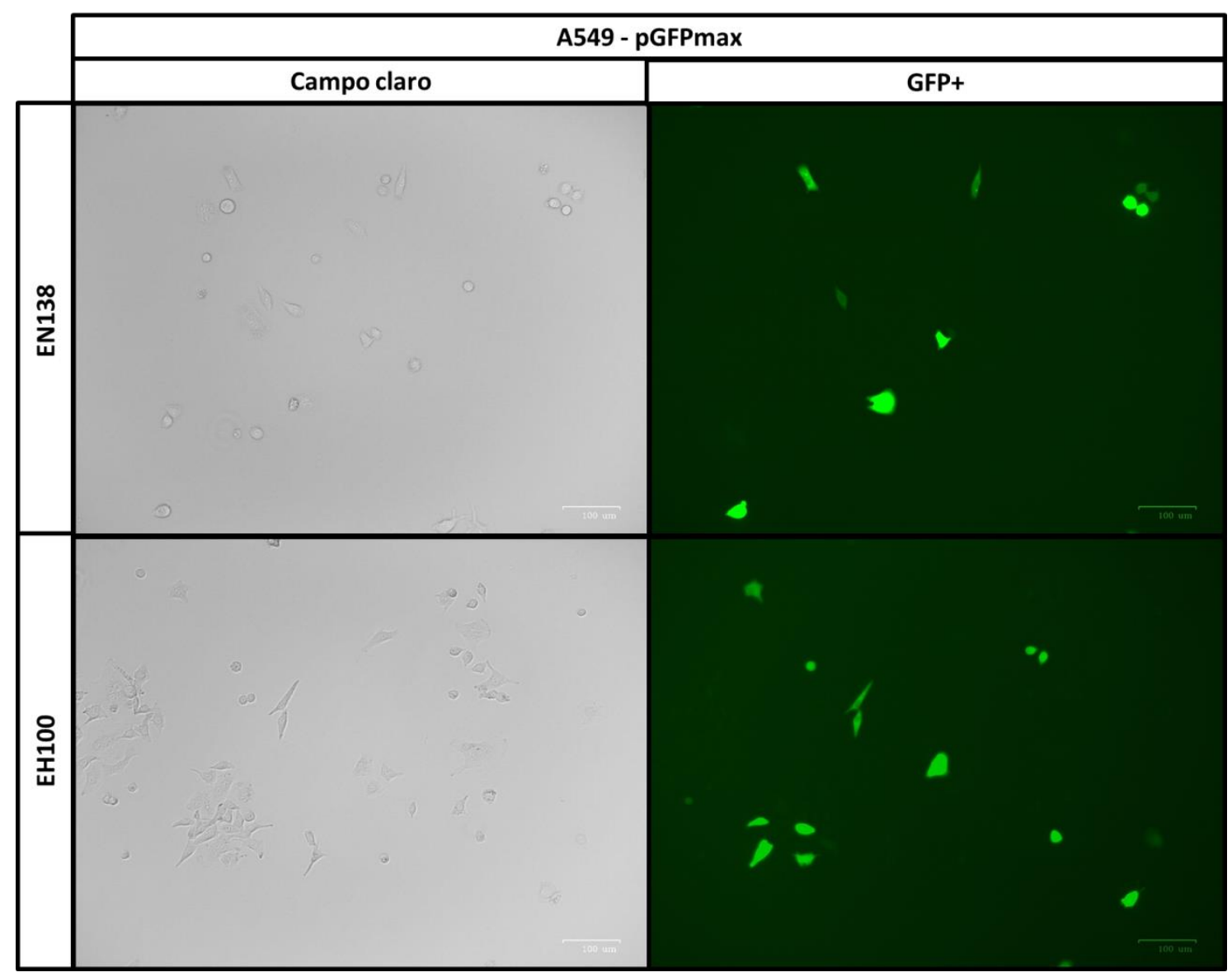

FONTE: Dados da autora.

Figura 13. Controle positivo da transfecção celular A549 por pGFPmax.. Células GFP+, com baixa eficácia, após o protocolo de transfecção por eletroporação, tanto para os pulsos EN138, quanto para EH100. 
Após $48 \mathrm{~h}$ à transfecção, as células foram selecionadas por puromicina 1 $\mu \mathrm{g} / \mathrm{mL}$, por pelo menos 5 dias, para garantir a seleção.

\subsection{Transfecção celular por lipofectamina}

Devido à baixa eficiência da transfecção do protocolo por eletroporação, foi decidido realizar concomitantemente o protocolo por lipofectamina. A princípio, pareceu que o a eficácia havia sido maior, pelo número de células que sobreviveram após $48 \mathrm{~h}$ à transfecção. Entretanto, após a adição da puromicina, houve muita morte celular, indicando uma baixa eficácia de transfecção também. Como o número de células era muito baixo, tanto do protocolo de eletroporação quanto por lipofectamina, optou-se por juntar as células correspondentes aos mesmos plasmídeos, a fim de conseguir expandir as células para seguir com os experimentos.

\subsection{Avaliação das proteínas envolvidas no processo autofágico}

Para avaliar se concentrações sub-citotóxicas de SF2 e cisplatina interferem na biogénese dos autofagossomos, investigou-se a família de proteínas relacionadas com a autofagia, as ATG. A análise por Western Blotting mostrou que o tratamento de SF2 com cisplatina afetou os sistemas de conjugação ATG5 e ATG7 e Beclin-1 foi reduzida nas células A549 (Figura 14). Desta forma, a inibição de PE por SF2 perturba o processo de formação fagófaro, prejudicando a formação da estrutura de membrana, impedindo a expansão do fagófaro para formar o autofagolissosomo.

O fluxo autofágico foi monitorado, comparando com os controles positivos pra indução e inbição da autofagia, pelo cultivo das células na ausência de soro e uso de cloroquina, respectivamente. Após 24 horas de tratamento, a conversão da proteína LC3-I para LC3-II foi bloqueada, pelo seu acúmulo observado (Figura 14). Consistente com nossa hipótese, foi demonstrado que o tratamento com SF2 associado à cisplatina bloqueou a conversão de LC3-I 
para LC3-II, mesmo em concentrações sub-citotóxicas, ficando mais evidente na presença de cloroquina (Figura 14).

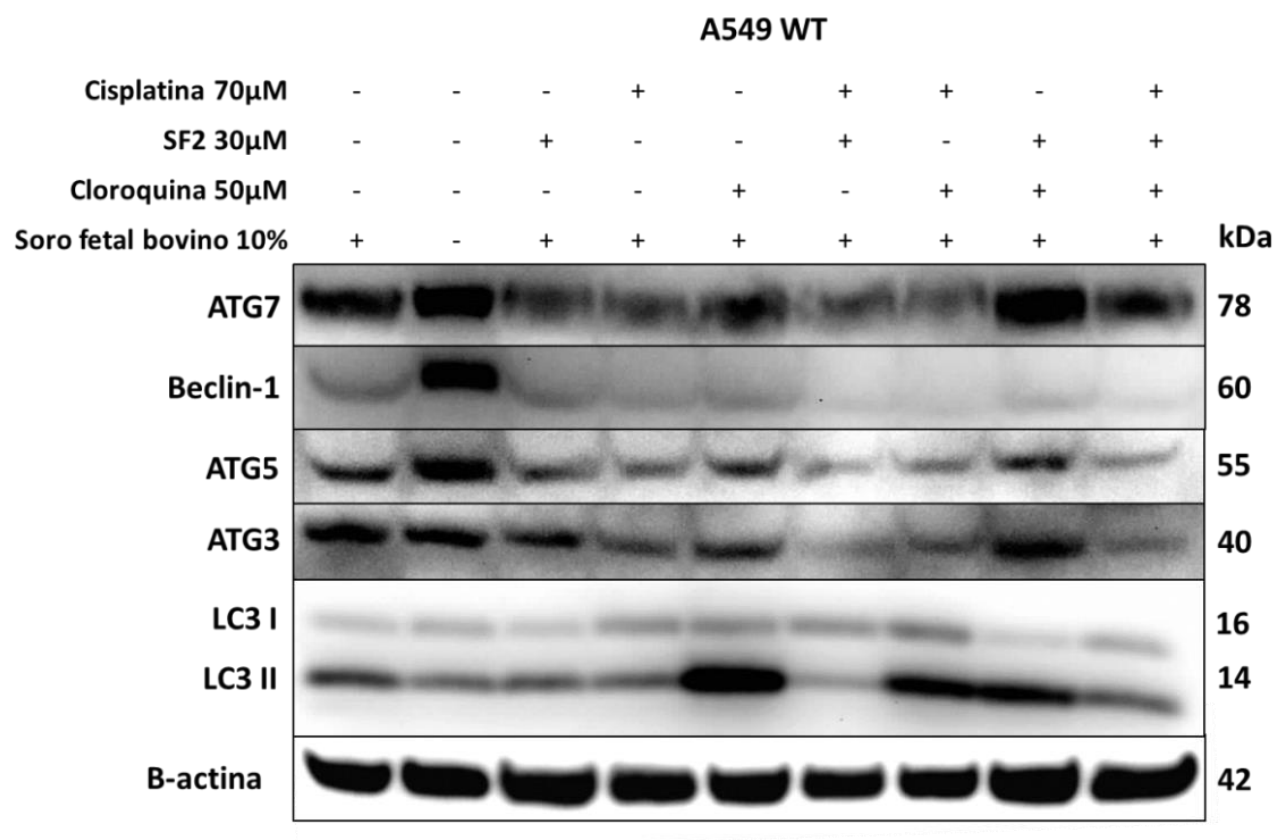

FONTE: Dados da autora.

Figura 14. Análise das proteínas relacionadas à autofagia em A549. Imagem representativa das membranas utilizadas para a detecção das proteínas de autofagia por Western Blotting das células A549, tratadas com SF2 $(30 \mu \mathrm{M})$ e/ou cisplatina $(70 \mu \mathrm{M})$ cloroquina $(50 \mu \mathrm{M})$.

\subsection{Confirmação do silenciamento por CRISPR/cas9}

Para confirmar se houve o silenciamento dos genes ATG5, ATG7, Beclin-1 e CHOP pela técnica de CRISPR/cas9, as expressões dessas proteínas foram avaliadas por Western blotting (Figura 15).

Como observado, o silenciamento dos genes estudos foi bem sucedido, exceto por CHOP, pois mesmo com as células resistentes à puromicina, continuou expressando a proteína. Portanto, os experimentos seguiram apenas com as outras três células silenciadas. 


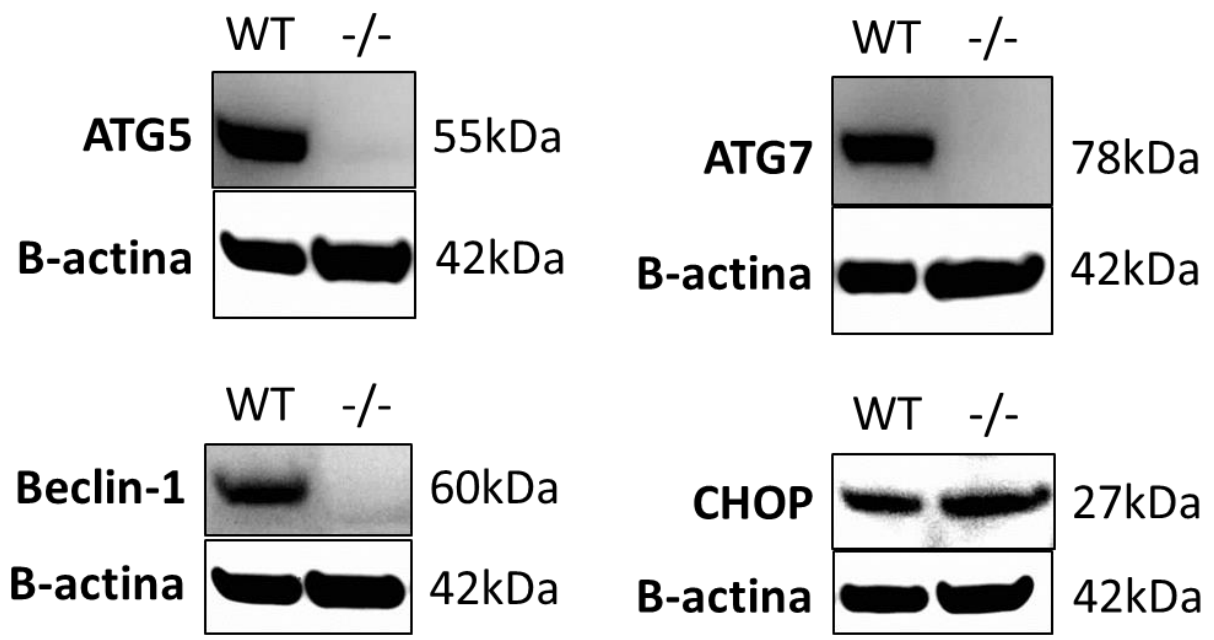

FONTE: Dados da autora

Figura 15. Confirmação do silenciamento dos genes ATG5, ATG7 e Beclin-1. Detecção das proteínas de autofagia por Western Blotting das células A549 após transfecção e seleção positiva por puromicina. Apenas CHOP não foi silenciada.

\subsection{Avaliação das proteínas envolvidas no processo autofágico nas células silenciadas}

Para entendermos melhor o processo autofágico, as proteínas que atuam na via da autofagia, p62 e LC3-I e II, foram analisadas e comparadas entre as das células selvagem com as das células silenciadas.

Na Figura 16, podemos confirmar que, devido ao silenciamento de ATG7, não há a formação de LC3-II em nenhum dos tratamentos, uma vez que ele é fundamental nesse processo. Já nas células silenciadas em ATG5, podemos ver a diferença de SF2, que bloqueia a autofagia nos estágios iniciais (produção de PE), com a cloroquina, que bloqueia a autofagia nos estágios finais (fusão do autofagossomo com lisossomo). Ao ser tratadas com SF2 houve o acúmulo de LC3-I e com cloroquina, de LC3-II. Já nas células com Beclin-1 silenciado, também observamos o acúmulo de LC3-I nas células tratadas com SF2 e de LC3-II, com cloroquina. 


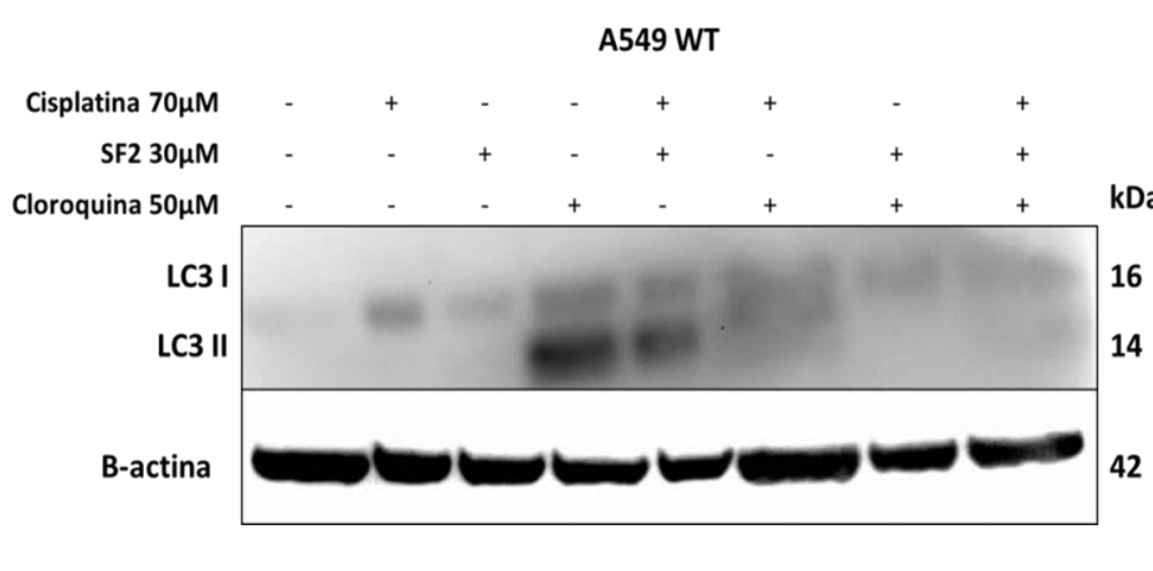

A549 ATG7 -/-
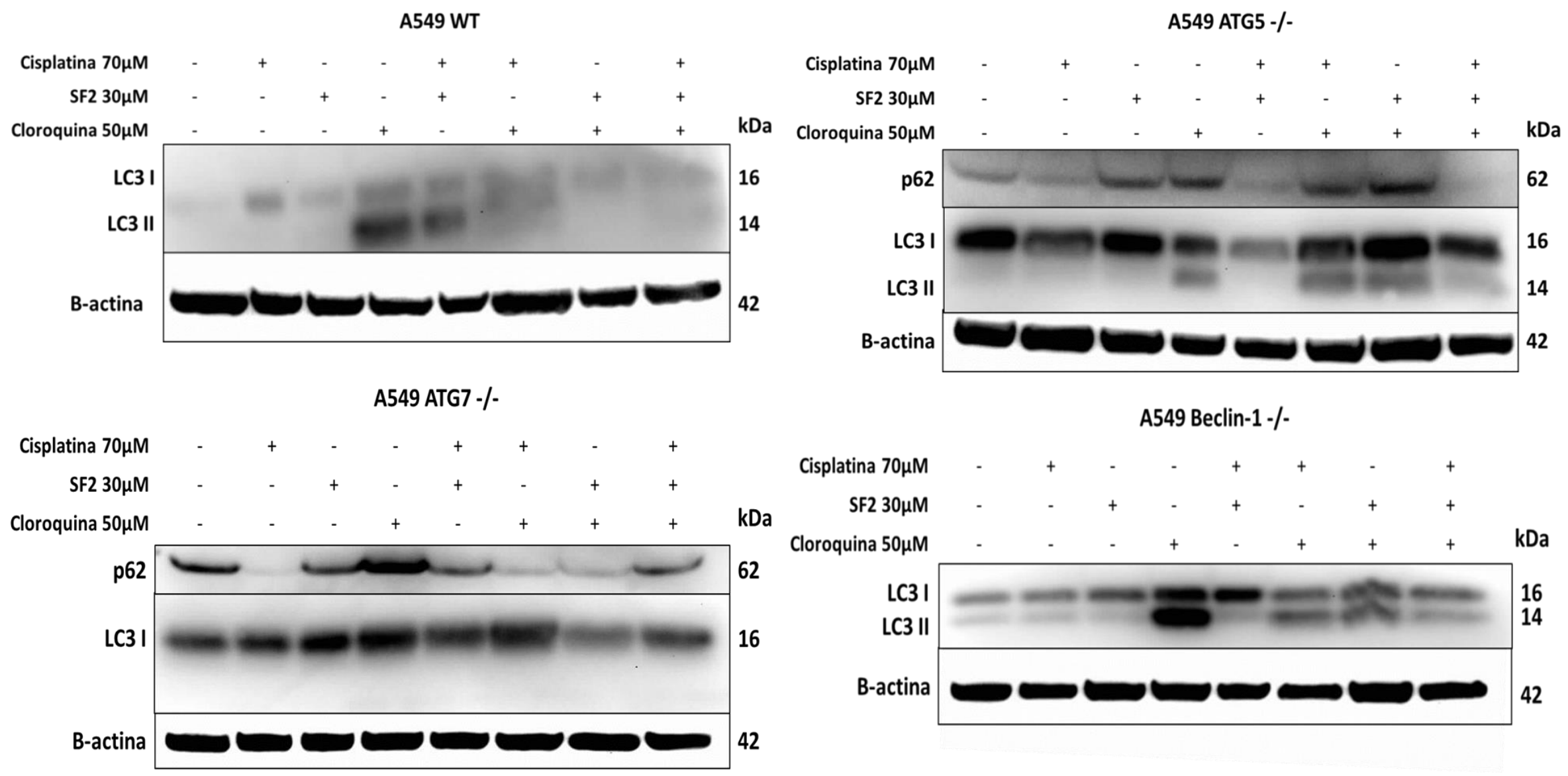

A549 Beclin-1 -/-

FONTE: Dados da autora

Figura 16. Análise das proteínas relacionadas à autofagia em A549 selvagem e silenciadas. Detecção das proteínas de LC3 e p62 por Western Blotting das células A549, tratadas com SF2 $(30 \mu \mathrm{M})$, cisplatina $(70 \mu \mathrm{M})$ e cloroquina $(50 \mu \mathrm{M})$. 


\subsection{Ensaio de citotoxicidade para avaliação dos efeitos da combinação de SF2 com cisplatina na linhagem A549 WT e silenciadas}

Para avaliar a citotoxicidade de SF2 nas células silenciadas, foi feito 0 ensaio de MTT. Na tabela 8 foram apresentados os valores de $\mathrm{IC}_{50}$ obtidos dos tratamentos de cisplatina, SF2 e suas combinações, além da combinação de SF2 em concentrações variadas com cloroquina a $50 \mu \mathrm{M}$. Na Tabela 9 é observado as porcentagens de viabilidade celular das células tratadas com cloroquina na concentração de $50 \mu \mathrm{M}$.

Tabela 8. Valores de IC50 $(\mu \mathrm{M})$

\begin{tabular}{rcccc}
\hline & \multicolumn{4}{c}{ IC $_{50}(\boldsymbol{\mu M}) \pm$ DP } \\
\hline Tratamentos & A549 WT & ATG5-/- & ATG7-/- & Beclin-1-/- \\
Cisplatina & $106 \pm 4$ & $99 \pm 20$ & $165 \pm 10$ & $125 \pm 10$ \\
SF2 & $72 \pm 5$ & $234 \pm 34$ & $135 \pm 20$ & $189 \pm 48$ \\
Cisplatina+SF2 & $51 \pm 7$ & $120 \pm 6$ & $138 \pm 22$ & $30 \pm 9$ \\
SF2+Cloroquina 50 $\boldsymbol{\mu M}$ & $31 \pm 6$ & $12 \pm 3$ & $105 \pm 1$ & $20 \pm 7$ \\
\hline
\end{tabular}

FONTE: Dados da autora.

Tabela 9. Porcentagens de viabilidade celular

\begin{tabular}{ccccc}
\hline & \multicolumn{4}{c}{ Porcentagem da Viabilidade celular } \\
\hline Tratamento & A549 WT & ATG5-/- & ATG7-/- & Beclin-1-/- \\
Cloroquina 50 $\mathrm{\mu M}$ & $71 \%$ & $54 \%$ & $75 \%$ & $81 \%$ \\
\hline
\end{tabular}

FONTE: Dados da autora. 


\subsection{Avaliação da citotoxicidade em Cultura 3D}

O sistema de levitação magnética foi utilizado para a formação dos esferoides. Após o período de tratamento, foram registradas imagens dos esferoides (Figuras 17A e 18A). Para avaliar o efeito dos tratamentos sobre 0 esferoide, a área de cada um foi medida e comparada pelo software Image $J$ (NIH, USA) (Figuras 17B e 18B).

Como é observado nas imagens (Figuras 17A e 18A), a combinação dos tratamentos de SF2 com cisplatina, foi muito superior quando comparadas aos compostos isolados. Os esferoides foram desestabilizados, evidenciando perda da matriz extracelular, levando ao aumento da área (Figuras 17B e 18B). Infelizmente, o tratamento também afetou as células não tumorais (Figuras 18A e 18B). 

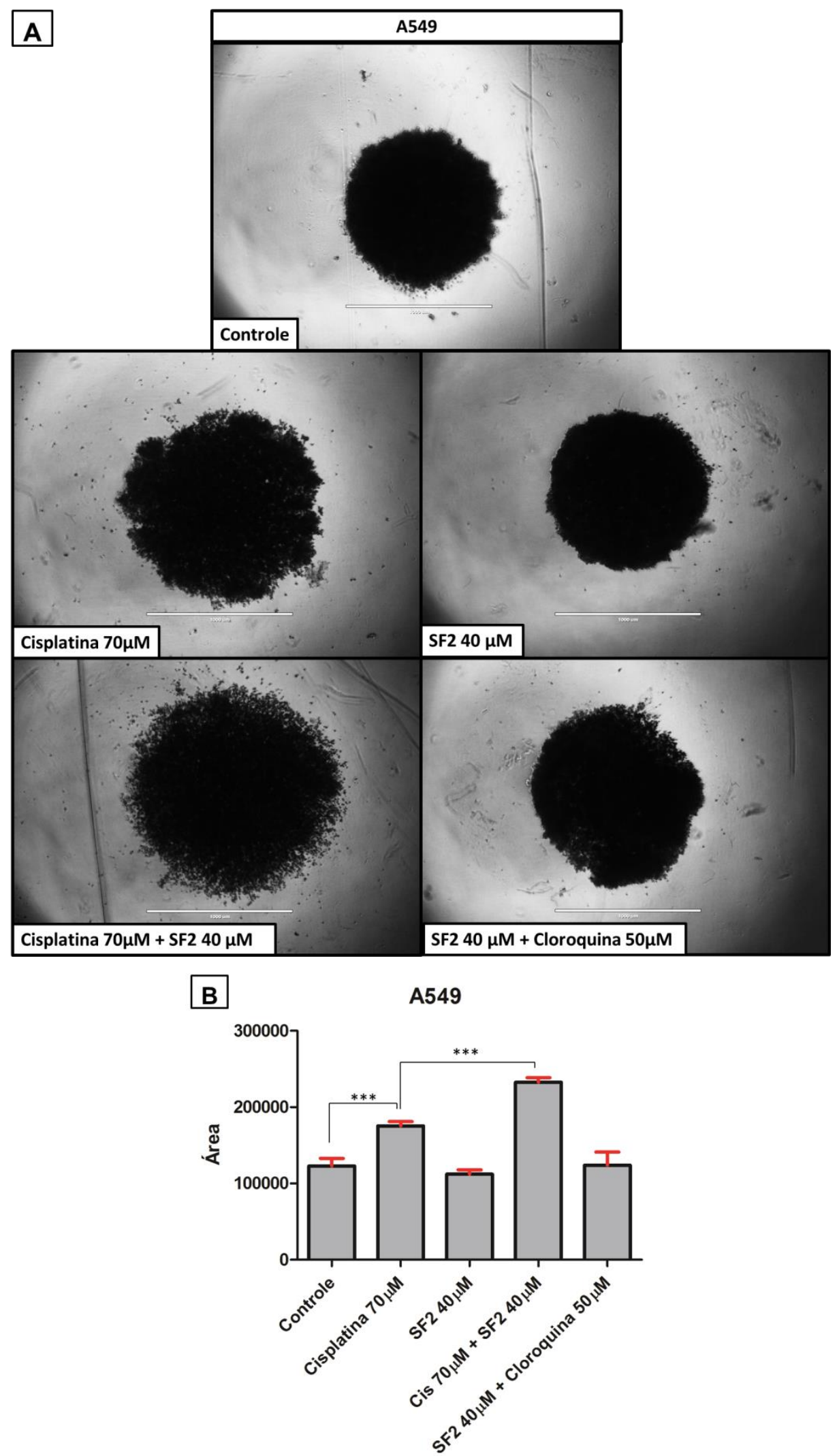

FONTE: Dados da autora.

Figura 17. Ensaio de citotoxicidade em cultura 3D de células A549. A) Esferoides de células A549 e seus respectivos tratamentos em campo claro (magnificação: barra de $1000 \mu \mathrm{m})$. B) Comparação da expansão de área entre os esferoides tratados e o controle. 


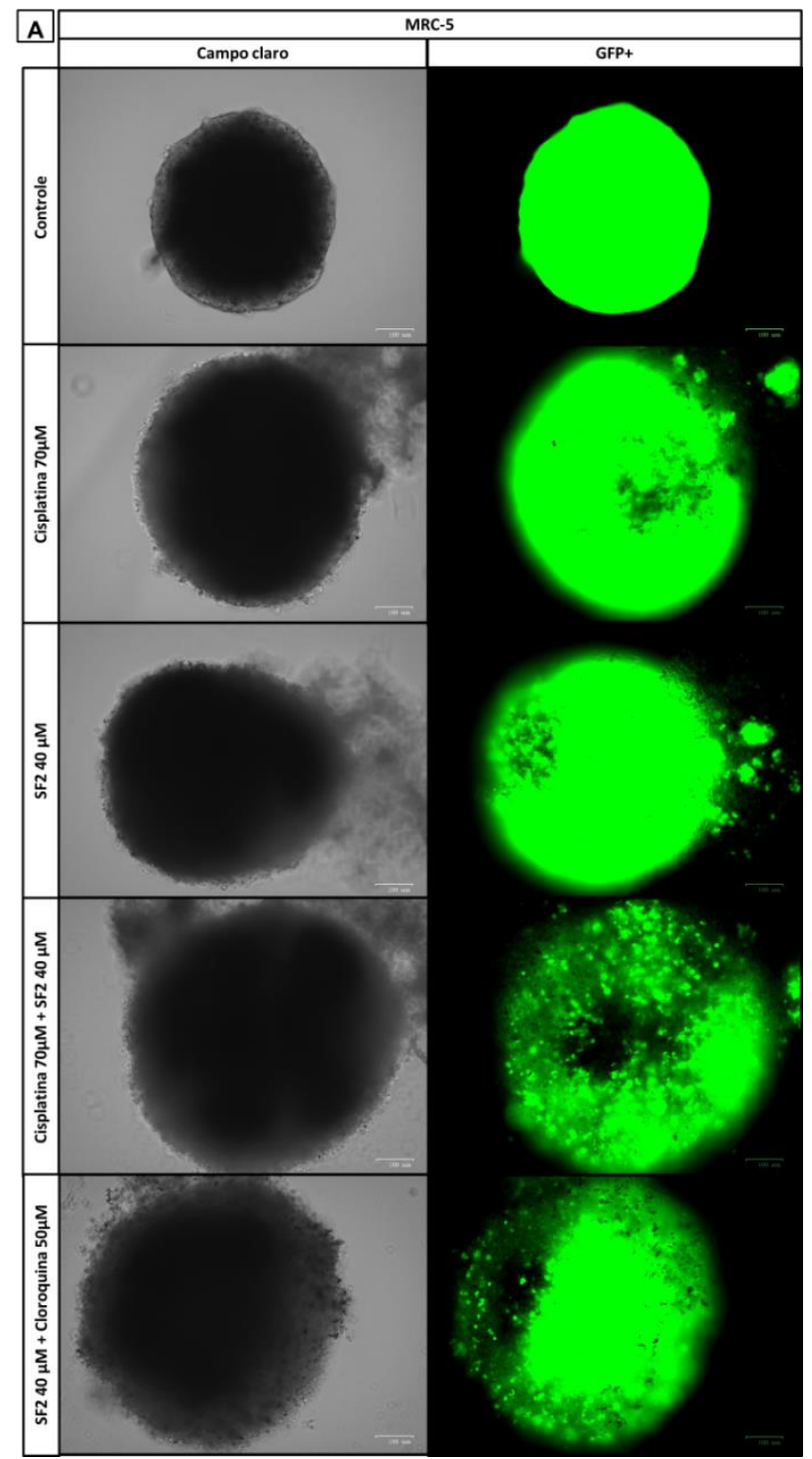

B

MRC-5

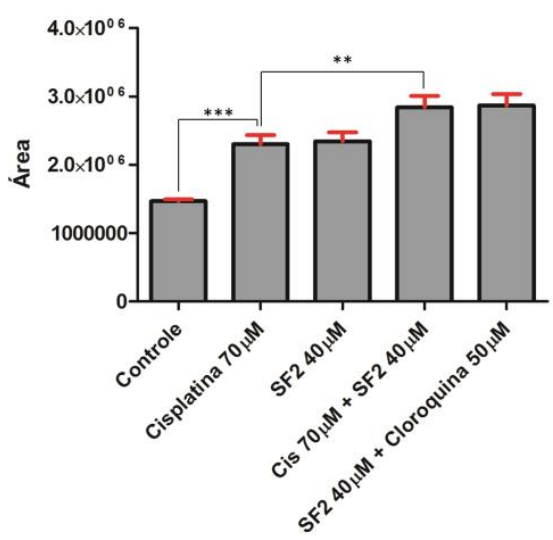

FONTE: Dados da autora.

Figura 18. Ensaio de citotoxicidade em cultura 3D de células MRC-5 GFP+. A) Imagem representativa dos esferoides de células A549 e seus respectivos tratamentos em campo claro (magnificação: barra de $1000 \mu \mathrm{m}$ ). B) Gráfico da área do esferoides para a comparação da expansão de área entre os esferoides tratados e o controle. 


\subsection{Avaliação das alterações morfológicas induzidas por SF2}

Com o intuito de observar as diferenças das alterações morfológicas causadas por SF2, cisplatina e cloroquina, além de suas combinações, foi utilizado o MET. Neste experimento, as células A549 foram tratadas por 24h com SF2 $(40 \mu \mathrm{M})$, cisplatina $(70 \mu \mathrm{M})$, cloroquina $(50 \mu \mathrm{M})$, e as combinações: cisplatina $(70 \mu \mathrm{M})$ com SF2 $(40 \mu \mathrm{M})$, cisplatina $(70 \mu \mathrm{M})$ com cloroquina $(50 \mu \mathrm{M})$ e SF2 $(40 \mu \mathrm{M})$ com cloroquina $(50 \mu \mathrm{M})$. Após o processamento das amostras, foram analisadas as alterações de: integridade celular e nuclear, mitocôndrias e retículo endoplasmático e vesículas autofágicas.

Na Figura 19, é possível observar que o tratamento com SF2 é capaz de induzir danos mitocondriais e alteração do RE nas células A549, corroborando com os dados obtidos por Western Blotting. As alterações das mitocôndrias corroboram os dados da redução de potencial mitocondrial anteriores por TMRE. É interessante destacar que há uma redução na produção de surfactante, com redução do número de corpos lamelares após o tratamento com SF2, porém há o aumento considerável quando o tratamento é combinado com cisplatina e com cloroquina, o que não é observado na combinação de cisplatina com cloroquina. 


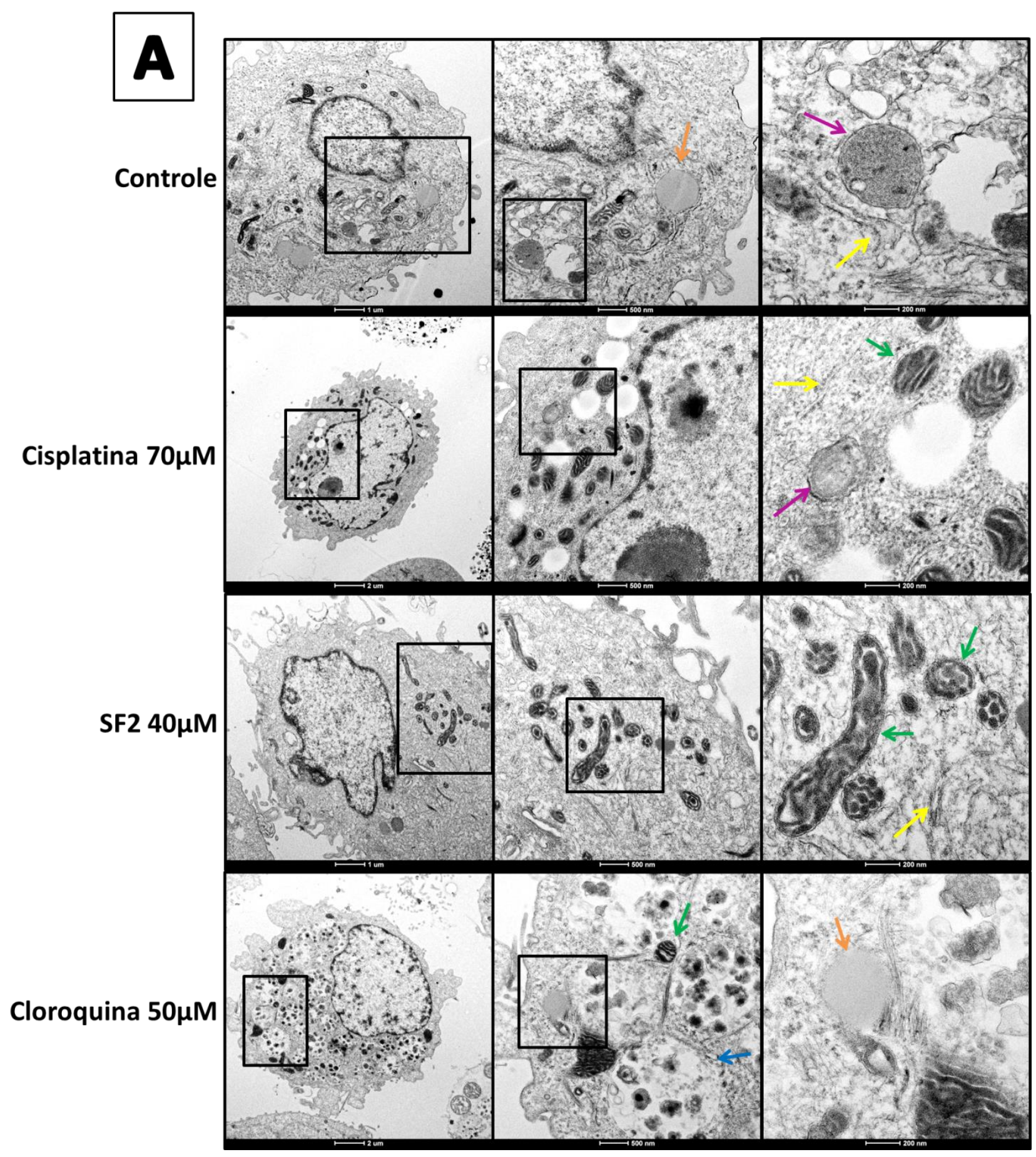




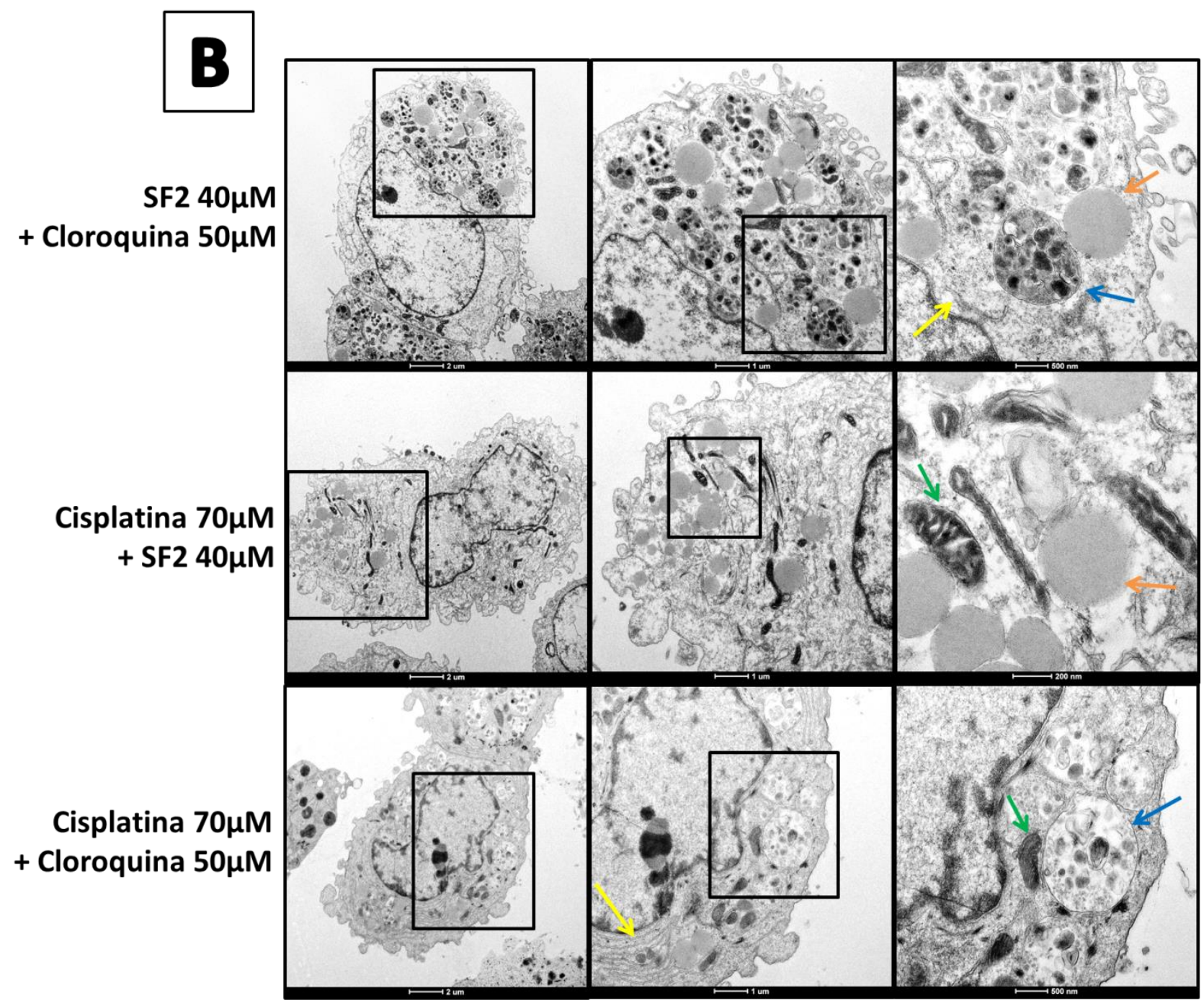

FONTE: Dados da autora.

Figura 19. Avaliação das alterações morfológicas em A549 induzidas por SF2 e combinações. A) comparação entre célula sem tratamento (Controle) e tratadas com os compostos Cisplatina, SF2 e cloroquina, isolados. B) comparação dos tratamentos em combinação. As setas laranjas indicam corpos lamelares, setas roxas: lisossomos, setas amarelas: RE, setas verdes: mitocôndrias, setas azuis: vesículas autofágicas. 


\section{DISCUSSÃO}

Em estudos prévios do grupo, foi identificado um novo composto classificado como "CHY-1", o qual foi capaz de inibir a Pcyt-2, um potencial alvo em câncer de pulmão. Além disso, foi identificado seu particular mecanismo de ação que envolve a redução do fluxo autofágico, um processo ainda não totalmente esclarecido. Em virtude disso, o atual projeto propôs-se a explorar o mecanismo relatado.

Inicialmente, os efeitos citotóxicos dos compostos; bevacizumab, cisplatina e taxol foram avaliados nas células A549, NCl-H1299, NCl-H292 e NCl-H460. O objetivo desta análise foi avaliar os efeitos citotóxicos e determinar os valores de $\mathrm{IC}_{50}$, com a finalidade de determinar concentrações subcitotóxicas para mensurar o possível efeito sinérgico com $\mathrm{CHY}-1$ e se a sua combinação terapêutica com outros agentes quimioterápicos poderia ser uma estratégia promissora para o tratamento de câncer de pulmão. No protocolo avaliado, quimioterápico paclitaxel e 0 anticorpo monoclonal bevacizumab, não apresentaram efeitos citotóxicos direto nas células de CPCNP nas concentrações e no tempo testados, sendo possível apenas calcular o valor de $\mathrm{IC}_{50}$ para a cisplatina.

Atualmente para o tratamento de CPCNP, é utilizado um regime de combinação entre dois agentes quimioterápicos. No entanto, a adição de um terceiro fármaco, não traz muitos benefícios terapêuticos, algumas vezes promove toxicidade secundária (66). Na busca por alternativas, estudos clínicos já testaram a associação da hidroxicloroquina (inibidor de autofagia), com diversos outros agentes terápicos, como o bevacizumab, carboplatina e paclitaxel, no combate ao câncer, incluindo o de pulmão (67). No entanto, o protocolo apresenta uma limitação, os pacientes ainda são suscetíveis aos graves efeitos adversos da hidroxicloroquina, como toxicidade ocular (58). Deste modo, foi avaliado se CHY-1 poderia ser associado com terapias já padronizadas para tratamento de câncer de pulmão. 
A cisplatina e a carboplatina são os derivados de platina mais utilizados como quimioterápicos de primeira linha no tratamento do câncer, incluindo o CPCNP (68). O mecanismo de ação desses compostos consiste em formar ligações cruzadas intrafilamentares e interfilamentares de DNA, impedindo a sua replicação e transcrição, além de promover quebras e erros de codificação (69). É muito utilizada em casos de pacientes com CPCNP metastático, e quase sempre em associação com algum fármaco alvo-dirigido, como o bevacizumab. Em geral, pacientes com metástase disseminada devem utilizar a cisplatina em ciclo com duração de 4 a 6 semanas. No entanto, a cisplatina é responsável por vários efeitos adversos, tais como: neuropatia periférica, sensação de formigamento e queimação (70).

O paclitaxel também é um dos quimioterápicos de primeira linha utilizados no tratamento de CPCNP em combinação com outro quimioterápico, geralmente um derivado de platina (12). Umas das justificativas para não se observar os efeitos citotóxicos nas linhagens, seria o seu mecanismo de ação. O paclitaxel promove a agregação dos microtúbulos, ligando-se à subunidade da $\beta$-tubulina, prevenindo a despolimerização e inibindo a reorganização da rede, consequentemente interrompendo a mitose (69).

Já o mecanismo de ação do anticorpo monoclonal bevacizumab é inibir o fator de crescimento endotelial vascular (VEGF-A, do inglês: Vascular endothelial growth factor $A$ ). Este efeito inibitório bloqueia a angiogênese tumoral, e promove a normalização da vascularização existente (71). A restauração do fluxo capilar auxilia diretamente o aumento da pressão intersticial, melhorando a biodisponibilidade de outros agentes quimioterápicos (72). Portanto, nestes protocolos in vitro, não é possível sugerir que não apresenta efeitos citotóxicos, ou mesmo que a sua combinação com $\mathrm{CHY}-1$ não apresentaram efeitos sinérgicos.

CHY-1 apresentou efeitos sinérgicos com cisplatina em todas as linhagens testadas. Uma das possíveis explicações seria o fato de que alguns trabalhos já comprovaram que, na tentativa de prevenir a morte celular, a autofagia é ativada após à exposição à cisplatina, além de estar relacionada com à quimioresistência (73)(74)(75). 
Com a confirmação de que CHY-1 inibia a atividade enzimática da Pcyt-2 em experimentos anteriores do grupo (dados não publicados), e por esta enzima estar localizada no RE, surgiu a hipótese de que sua inibição poderia afetar a homeostase do RE, cuja manutenção envolve desde a síntese até o transporte proteico (76). Como pôde ser observado nas figuras 2 e 3, o CHY-1 aumentou a expressão de PERK e IRE1 $\alpha$, enzimas que atuam como sensores moleculares e são ativadas com a finalidade de eliminar o estresse do RE, levando à morte celular (77). Quanto ao aumento da expressão da proteína CHOP, fator de transcrição conhecido como principal mediador da apoptose estimulada pela ativação da UPR, indica que houve acúmulo de proteínas desdobradas, o qual induz ao aumento de estresse, podendo estar associado com a morte celular programada e/ou apoptose das células NCl-H460 e A549 (78).

A indução de autofagia tem emergido como um mecanismo de resistência à quimioterapia, bem como, a promoção da sobrevivência de células tumorais por auto-renovação (38). O RE desempenha um papel crucial na iniciação de autofagia, especialmente na formação de partículas lipídicas iniciais, denominadas de fagóforos ou membranas de isolamento. Estas membranas são formadas na fase de alongamento do fagóforo, e apresentam como base de sustentação, a PE (79). A PE atua também como um lipídio ancorador da proteína LC3 (80). Decorrente da redução da produção de PE induzida pelo CHY-1, nas células $\mathrm{NCl}-\mathrm{H} 460$ e A549, houve um distúrbio da topologia das vesículas autofágicas. Para que LC3-I possa ser convertida à LC3-II, obrigatoriamente a PE necessita produzir interações com LC3-I formando assim, a LC3-II (PE-LC3-I), originando o autofagossomo. Na última etapa, ocorre a fusão do autofagossomo com o lisossomo formando o autolisossomo (81). Como CHY-1 inibe a biossíntese de PE, foi avaliado se, em concentrações sub-citotóxicas em combinação com cisplatina, levaria à inibição de PE e do fluxo autofágico nas células A549 e NCl-H460 por Western Blotting. O fluxo autofágico foi monitorado pelo pré-tratamento de $1 \mathrm{~h}$ com inibidores de autofagia, a bafilomicina $A_{1}$ e a cloroquina. Após 24 horas de tratamento, a conversão da proteína LC3-I para LC3-II, foi bloqueada em ambas as linhagens 
de CPCNP. Consistente com nossa hipótese, foi demonstrado que CHY-1 associado à cisplatina bloqueia a conversão de LC3-I para LC3-II, mesmo em concentrações sub-citotóxicas, ficando mais evidente na presença de bafilomicina $A_{1}$ (Figuras 2 e 3 ).

Conforme mencionado anteriormente, houve um problema em uma das etapas de síntese e purificação de CHY-1. Portanto, foi dado a continuidade neste trabalho utilizando o composto denominado SF2. Como foi observado na Tabela 5, SF2 não apresentou a mesma citotoxicidade de CHY-1, mas foi mais citotóxica que cisplatina para A549. Além disso, foi comprovado que SF2 possui também a capacidade de inibir a enzima Pcyt-2 e diminuir o transporte e etanolamina intracelular (Tabela 6 e 7).

Com esses dados, avaliou-se os mecanismos de morte celular pelo ensaio de anexina $\mathrm{V} / \mathrm{PI}$, o qual permite a avaliação da população apoptótica de uma amostra, uma vez que nesta há a exposição de fosfatidilserina, um dos marcos iniciais da apoptose, que se liga à anexina $V$ marcada com Alexafluor488 (82). Paralelamente, há avaliação da incorporação do PI ao DNA, que indica estágios mais tardios da apoptose ou outros tipos de morte celular, como a necrose (83). Tanto o tratamento com SF2 quanto com cisplatina foram capazes induzir a exposição de fosfatildilserina pelas células A549 e NCl-H460, indicando que o efeito de ambos estes compostos está relacionado à indução de apoptose nestas linhagens (Figura 4 e 5). Porém, a porcentagem de células positivas para anexina $V$ ainda é pouca para indicar a apoptose como a principal via de morte celular envolvida na citotoxicidade de SF2, principalmente para as células $\mathrm{NCl}-\mathrm{H} 460$, indicando que o mecanismo de ação de SF2 seja diferente entre essas duas linhagens.

O processo de morte celular pode estar relacionado a alterações no potencial transmembranar mitocondrial (84), o qual foi analisado através de uma sonda catiônica TMRE, que se acumula em mitocôndrias funcionais devido a sua carga membranar relativamente negativa (Figuras 6 e 7). Em ambas as células, o potencial de membrana mitocondrial diminuiu nas maiores concentrações testadas de SF2, comprovando danos mitocondriais, sendo que para cisplatina não teve efeito. Uma das hipóteses seria de que SF2 possa 
estar induzindo as células à senescência, uma vez que a autofagia, as funções mitocondrial e lisossomal estão diretamente relacionadas com 0 envelhecimento celular (85). Entretanto, ainda faltam muitos estudos e resultados para confirmar isso.

O sistema CRISPR/Cas9 é uma nova tecnologia que vem sendo amplamente utilizada na edição genômica. Essa técnica consiste na inserção de um bacteriófago ou plasmídeo contendo um fragmento de um DNA, que servirá como guia para a nuclease Cas clivar o DNA alvo (86). Para tentar elucidar o mecanismo de ação de SF2 na via da autofagia, foram adquiridos três plasmídeos contendo os fragmentos dos genes: ATG5, ATG7 e Beclin-1. O ensaio se mostrou ser bastante complexo, uma vez que foi necessário a execução de dois protocolos diferentes para a obtenção das células transfectadas e selecionadas. Na Figura 15, é possível confirmar que 0 silenciamento foi bem sucedido.

No fluxo autofágico, ATG4 cliva a pro-LC3, formando LC3-I, a qual é conjugada com a PE pela ATG7, formando a LC3-II. LC3-II é recrutada na membrana do fagófaro para ajudar na elongação da membrana do autofagossomo. ATG7 também auxilia a formação do complexo ATG5-ATG12ATG16, o qual, junto com a LC3-II, é crucial para a formação do autofagossomo. A proteína adaptadora p62/SQSTM1 liga-se a proteínas ubiquitinadas e a LC3-II para mediar a autofagia através da localização em compartimentos autofágicos, transportando proteínas e organelas ubiquitinadas para degradação. Beclin-1 junto com VPS34, VPS15 e ATG14, formam um complexo que leva à formação de fosfatidilinositol-3-fosfato, que também é necessário para a formação do fagófaro (46).

Ao analisar os dados de citotoxicidade dos compostos nas células silenciadas, a maioria indicou que os silenciamentos dos genes tornaram as células menos sensíveis aos tratamentos. Entretanto há um sinergismo quando é combinado os tratamentos (cisplatina + SF2 e SF2 + cloroquina). A via da autofagia é regulada por diversas vias de sinalização, como a via da fosfatidilinositol 3-quinase (PI3K) e mTOR (do inglês: mammalian target of rapamycin) (87)(88)(89). 
Os sistemas de cultura celular são indispensáveis nos estudos de triagem de novos fármacos. Os testes preliminares se iniciam no modelo clássico de cultura em monocamada bidimensional (cultura 2D), entretanto estas acabam sendo menos preditivas, uma vez que não mimetizam o microambiente tumoral, e as células são expostas de forma homogênea ao composto, aumentando a sensibilidade (90). Para contornar estes entraves e aumentar a predição dos efeitos antitumorais de SF2, células tumorais (A549) e não tumorais (MRC5 GFP+), foram cultivadas em um sistema de cultura 3D.

Como é possível observar nas Figuras 17 e 18, SF2 apresentou citotoxicidade tanto para a linhagem tumoral (A549), quanto para a não tumoral (MRC-5). Com esses resultados ficou evidente que SF2 não apresentou seletividade para a linhagem tumoral, o que foi decisivo para não iniciar os testes in vivo.

Pelas imagens por MET, na Figura 19, é observado as diferenças morfológicas entre os tratamentos por SF2 e cloroquina. SF2, por inibir o início da autofagia, não há presença de vacúolos, como é observado nas célula tratada com cloroquina, que inibe a fusão dos autofagossomos com os lisossomos. As células A549 são alveolares do tipo II e apresentam alta produção de surfactantes, mas principalmente a dipalmitoilfosfatidilcolina, utilizando a via de Kennedy (91). Desta forma, este dado pode ser um indicativo de que o SF2 está de fato agindo sobre a via de produção de fosfolipídios, uma vez que as células tratadas apresentaram uma redução na produção de seu surfactante, conforme o observado nas imagens da MET. Entretanto, suas combinações, com cisplatina e cloroquina, possam estar anulando o seu efeito, ou deslocando a via de forma compensatória, o que justificaria o aumento dos corpos lamelares. 


\section{CONCLUSÕES}

Foi verificado que paclitaxel e cisplatina apresentam citotoxicidade para as células de CPCNP apenas em elevadas concentrações. Em contraste, CHY-1 apresentou efeito in vitro superior aos quimioterápicos em todas as linhagens testadas. Outro fato demonstrado foi que as combinações em dose subcitotóxica de CHY-1 com a cisplatina ou com o paclitaxel apresentaram efeitos citotóxicos superiores aos ativos isolados, além de induzir o estresse do RE e reduzir o fluxo autofágico. Apesar de tais fatos indicarem que CHY-1 seria um novo composto promissor para o desenvolvimento de uma nova classe de compostos quimioterápicos, sua síntese se tornou inviável.

Devido à dificuldade de se obter $\mathrm{CHY}$-1, foram iniciados novos testes com o seu intermediário SF2, cuja rota de síntese e purificação é menos complexa. O SF2 reduziu o fluxo autofágico das células $\mathrm{NCl}-\mathrm{H} 460$ e A549, pela inibição da enzima Pcyt-2 e do transporte de etanolamina intracelular, portanto é bem provável que essa molécula esteja relacionada com o grupo farmacofórico de $\mathrm{CHY}$-1. Os resultados do ensaio de Anexina/PI indicaram que a combinação de SF2 com cisplatina induz preferencialmente apoptose. Além disso, o SF2 foi capaz de reduzir o potencial elétrico da membrana mitocondrial das células A549 e NCl-H460, indicando a participação mitocondrial no processo de morte celular. SF2 se mostrou capaz de diminuir o fluxo autofágico, observado pela diminuição das proteínas: ATG5, ATG7, Beclin-1 e LC3 I e II, por Western blotting, resultados semelhantes ao previamente demonstrado por $\mathrm{CHY}-1$ na linhagem A549. Pela técnica de CRISPR/Cas9 (do inglês: Clustered Regularly Interspaced Short Palindromic Repeats), foram obtidas as células A549 knockout para os genes envolvidos no processo autofágico: ATG5, ATG7 e Beclin-1. Os resultados obtidos mostraram que, por mais que todas essas proteínas estejam relacionadas com a autofagia, as células se comportaram diferente para cada silenciamento. As imagens obtidas por MET corroboram com a hipótese de que SF2 reduz o fluxo autofágico de forma diferente da cloroquina, além de induzir alterações morfológicas da mitocôndria e RE. A combinação em dose sub-citotóxica de SF2 e cisplatina não apresentou efeitos 
citotóxicos superiores aos ativos isolados na cultura 2D, mas apresentou na 3D. Porém os tratamentos também foram tóxicos na cultura 3D para a linhagem não tumoral (MRC-5). Desta forma, podemos sugerir que o SF2 tem potencial para se tornar um novo fármaco para o tratamento de CPCNP, porém necessita modificações para potencializar o seu efeito e melhorar a seletividade a células tumorais. 


\section{REFERÊNCIAS}

1. Bray F, Ferlay J, Soerjomataram I, Siegel RL, Torre LA, Jemal A. Global cancer statistics 2018: GLOBOCAN estimates of incidence and mortality worldwide for 36 cancers in 185 countries. CA Cancer J Clin. 2018;68(6):394-424.

2. Instituto Nacional de Câncer - INCA, Estimativas da incidência e mortalidade por câncer. [Internet]. Ministério da Saúde. 2018. 128 p. Available at: http://www.inca.gov.br/estimativa/2018/estimativa-2018.pdf

3. Hanahan D, Weinberg RA. Hallmarks of Cancer: The Next Generation. Cell [Internet]. março de 2011;144(5):646-74. Available at: http://dx.doi.org/10.1016/j.cell.2011.02.013

4. Ferlay J, Soerjomataram I, Dikshit R, Eser S, Mathers C, Rebelo M, et al. Cancer incidence and mortality worldwide: Sources, methods and major patterns in GLOBOCAN 2012. Int J Cancer. 2015;136(5):E359-86.

5. Siegel RL, Miller KD, Jemal A. Cancer statistics, 2018. CA Cancer J Clin [Internet]. 2018;68(1):7-30.

Available

at: http://doi.wiley.com/10.3322/caac.21442

6. Sabari JK, Lok BH, Laird JH, Poirier JT, Rudin CM. Unravelling the biology of SCLC: Implications for therapy. Nat Rev Clin Oncol [Internet]. 2017;14(9):549-61.

Available

at: http://dx.doi.org/10.1038/nrclinonc.2017.71

7. Herbst RS, Morgensztern D, Boshoff C. The biology and management of non-small cell lung cancer. Nature [Internet]. 2018;553(7689):446-54. Available at: http://dx.doi.org/10.1038/nature25183

8. Shien K, Toyooka S, Ichimura K, Soh J, Furukawa M, Maki $\mathrm{Y}$, et al. Prognostic impact of cancer stem cell-related markers in non-small cell lung cancer patients treated with induction chemoradiotherapy. Lung Cancer [Internet]. 2012;77(1):162-7. Available at: 
http://dx.doi.org/10.1016/j.lungcan.2012.02.006

9. Maurizi G, D’Andrilli A, Ciccone AM, Ibrahim M, Andreetti C, Tierno S, et al. Margin distance does not influence recurrence and survival after wedge resection for lung cancer. Ann Thorac Surg. 2015;100(3):918-25.

10. Postmus PE, Kerr KM, Oudkerk M, Senan S, Waller DA, Vansteenkiste J, et al. Early and locally advanced non-small-cell lung cancer (NSCLC): ESMO Clinical Practice Guidelines for diagnosis, treatment and follow-up. Ann Oncol. 2017;28(Supplement 4):iv1-21.

11. Miller KD, Nogueira L, Mariotto AB, Rowland JH, Yabroff KR, Alfano CM, et al. Cancer treatment and survivorship statistics, 2019. CA Cancer J Clin. 2019;0(0):1-23.

12. Liang J, Bi N, Wu S, Chen M, Lv C, Zhao L, et al. Etoposide and cisplatin versus paclitaxel and carboplatin with concurrent thoracic radiotherapy in unresectable stage III non-small cell lung cancer: A multicenter randomized phase III trial. Ann Oncol. 2017;28(4):777-83.

13. Ladanyi M, Pao W. Lung adenocarcinoma: Guiding EGFR-targeted therapy and beyond. Mod Pathol. 2008;21:S16-22.

14. Gautschi O, Milia J, Cabarrou B, Bluthgen MV, Besse B, Smit EF, et al. Targeted therapy for patients with BRAF-mutant lung cancer results from the European EURAF cohort. $J$ Thorac Oncol [Internet]. 2015;10(10):1451-7. Available at: http://dx.doi.org/10.1097/JTO.0000000000000625

15. Shigematsu H, Takahashi T, Nomura M, Majmudar K, Suzuki M, Lee H, et al. Somatic Mutations of the HER2 Kinase Domain in Lung Adenocarcinomas. Cancer Res [Internet]. 2005;65(5):1642-6. Available at: http://cancerres.aacrjournals.org/lookup/doi/10.1158/0008-5472.CAN04-4235

16. Shaw AT, Kim D-W, Mehra R, Tan DSW, Felip E, Chow LQM, et al. Ceritinib in ALK -Rearranged Non-Small-Cell Lung Cancer . N Engl J 
Med. 2014;370(13):1189-97.

17. Bergethon K, Shaw AT, Ignatius Ou S-H, Katayama R, Lovly CM, McDonald NT, et al. ROS1 Rearrangements Define a Unique Molecular Class of Lung Cancers. J Clin Oncol [Internet]. 2012;30(8):863-70. Available at: http://ascopubs.org/doi/10.1200/JCO.2011.35.6345

18. Osmani L, Askin F, Gabrielson E, Li QK. Current WHO guidelines and the critical role of immunohistochemical markers in the subclassification of non-small cell lung carcinoma (NSCLC): Moving from targeted therapy to immunotherapy. Semin Cancer Biol [Internet]. 2018;52(Pt 1):103-9. Available at: https://linkinghub.elsevier.com/retrieve/pii/S1044579X17300974

19. Tartari F, Santoni M, Burattini L, Mazzanti P, Onofri A, Berardi R. Economic sustainability of anti-PD-1 agents nivolumab and pembrolizumab in cancer patients: Recent insights and future challenges. Cancer Treat Rev [Internet]. 2016;48:20-4. Available at: http://dx.doi.org/10.1016/j.ctrv.2016.06.002

20. Gibellini F, Smith TK. The Kennedy pathway-de novo synthesis of phosphatidylethanolamine and phosphatidylcholine. IUBMB Life. 2010;62(6):414-28.

21. Levy JMM, Towers CG, Thorburn A. Targeting autophagy in cancer. Nat Rev Cancer [Internet]. 28 de setembro de 2017;17(9):528-42. Available at: http://dx.doi.org/10.1038/nrc.2017.53

22. Cheng M, Bhujwalla ZM, Glunde K. Targeting Phospholipid Metabolism in Cancer. Front. Oncol. 2016;6(December):1-17.

23. Li Z, Agellon LB, Allen TM, Umeda M, Jewell L, Mason A, et al. The ratio of phosphatidylcholine to phosphatidylethanolamine influences membrane integrity and steatohepatitis. Cell Metab [Internet]. 2006;3(5):321-31. Available at: https://linkinghub.elsevier.com/retrieve/pii/S1550413106001161 
24. Escribá P V, Busquets X, Inokuchi J, Balogh G, Török Z, Horváth I, et al. Membrane lipid therapy: Modulation of the cell membrane composition and structure as a molecular base for drug discovery and new disease treatment. Progress in Lipid Research 2015;59:38-53.

25. Valenzuela-oses JK, García MC, Feitosa VA, Pachioni-vasconcelos JA, Gomes-filho SM, Lourenço FR, et al. Materials Science \& Engineering C Development and characterization of miltefosine-loaded polymeric micelles for cancer treatment. Mater Sci Eng $C$ [Internet]. 2017;81(June):327-33. Available

at: http://dx.doi.org/10.1016/j.msec.2017.07.040

26. Ramos B, Mouedden M El, Claro E, Jackowski S. Inhibition of CTP:Phosphocholine Cytidylyltransferase by $\mathrm{C} 2$-Ceramide and Its Relationship to Apoptosis. Mol Pharmacol [Internet]. 2002;62(5):1068-75. Available at: http://molpharm.aspetjournals.org/lookup/doi/10.1124/mol.62.5.1068

27. Yosifov DY, Kaloyanov KA, Guenova ML, Prisadashka K, Balabanova $\mathrm{MB}$, Berger MR, et al. Alkylphosphocholines and curcumin induce programmed cell death in cutaneous T-cell lymphoma cell lines. Leuk Res [Internet]. 2014;38(1):49-56. Available at: http://dx.doi.org/10.1016/j.leukres.2013.10.011

28. Gajate C, Matos-da-Silva M, Dakir EL-H, Fonteriz RI, Alvarez J, Mollinedo F. Antitumor alkyl-lysophospholipid analog edelfosine induces apoptosis in pancreatic cancer by targeting endoplasmic reticulum. Oncogene [Internet]. 2012;31(21):2627-39. Available at: http://dx.doi.org/10.1038/onc.2011.446

29. Gohil VM, Zhu L, Baker CD, Cracan V, Yaseen A, Jain M, et al. Meclizine inhibits mitochondrial respiration through direct targeting of cytosolic phosphoethanolamine metabolism. J Biol Chem. 2013;288(49):35387-95.

30. Pavlovic Z, Singh RK, Bakovic M. A novel murine CTP: Phosphoethanolamine cytidylyltransferase splice variant is a post- 
translational repressor and an indicator that both cytidylyltransferase domains are required for activity. Gene [Internet]. 2014;543(1):58-68. Available at: http://dx.doi.org/10.1016/j.gene.2014.04.005

31. Taylor A, Schenkel LC, Yokich M, Bakovic M. Adaptations to excess choline in insulin resistant and Pcyt2 deficient skeletal muscle. Biochem Cell Biol [Internet]. 2017;95(2):223-31. Available at: https://www.nrcresearchpress.com/doi/pdf/10.1139/bcb-2016-0105

32. Zhu L, Johnson $\mathrm{C}$, Bakovic $M$. Stimulation of the human CTP:phosphoethanolamine cytidylyltransferase gene by early growth response protein 1. J Lipid Res [Internet]. 2008;49(10):2197-211. Available at: https://cb4nzpb-nkbotg.sec.amc.nl/content/49/10/2197.full

33. Zhu L, Bakovic M. Breast cancer cells adapt to metabolic stress by increasing ethanolamine phospholipid synthesis and CTP:ethanolaminephosphate cytidylyltransferase-Pcyt2 activity. Biochem Cell Biol [Internet]. 2012;90(2):188-99. Available at: http://www.nrcresearchpress.com/doi/10.1139/011-081

34. Mizushima N. Autophagy: process and function. Genes Dev [Internet]. 2007;21(22):2861-73.

Available

at: http://www.ncbi.nlm.nih.gov/pubmed/27664235\%0Ahttp://ww

35. Glick D, Barth S, Macleod KF. Autophagy: cellular and molecular mechanisms. The Journal of Pathology, 221, 3-12. http://doi.org/10.1002/path.2697. J Pathol [Internet]. 2010;221(1):3-12. Available at: http://www.ncbi.nlm.nih.gov/pubmed/20225336

36. Li W, Li J, Bao J. Microautophagy: lesser-known self-eating. Cell Mol Life Sci [Internet]. 12 de abril de 2012;69(7):1125-36. Available at: http://link.springer.com/10.1007/s00018-011-0865-5

37. Cuervo AM, Wong E. Chaperone-mediated autophagy: Roles in disease and aging. Cell Res [Internet]. 2014;24(1):92-104. Available at: http://dx.doi.org/10.1038/cr.2013.153 
38. Zhou A, Li S, Khan FA, Zhang S. Autophagy postpones apoptotic cell death in PRRSV infection through Bad-Beclin1 interaction. Virulence [Internet]. 17 de fevereiro de 2016;7(2):98-109. Available at: https://www.tandfonline.com/doi/full/10.1080/21505594.2015.1131381

39. Mizushima N, Komatsu M. Autophagy: Renovation of cells and tissues. Cell [Internet]. 2011;147(4):728-41. Available at: http://dx.doi.org/10.1016/j.cell.2011.10.026

40. Lampert MA, Gustafsson ÅB. Mitochondria and autophagy in adult stem cells: proliferate or differentiate. J Muscle Res Cell Motil [Internet]. 2019. Available at: http://link.springer.com/10.1007/s10974-019-09542-w

41. Rubinsztein DC, Mariño G, Kroemer G. Autophagy and aging. Cell. 2011;146(5):682-95.

42. Galluzzi L, Pietrocola F, Bravo-San Pedro JM, Amaravadi RK, Baehrecke $\mathrm{EH}$, Cecconi $\mathrm{F}$, et al. Autophagy in malignant transformation and cancer progression. EMBO J. 2015;34(7):856-80.

43. Di Malta C, Cinque L, Settembre C. Transcriptional Regulation of Autophagy: Mechanisms and Diseases. Front Cell Dev Biol [Internet]. 2019;7(July):1-10. Available

at: https://www.frontiersin.org/article/10.3389/fcell.2019.00114/full

44. White E. Deconvoluting the context-dependent role for autophagy in cancer. Nat Rev Cancer [Internet]. 2012;12(6):401-10. Available at: http://dx.doi.org/10.1038/nrc3262

45. Fais S, Overholtzer M. Cell-in-cell phenomena in cancer. Nat Rev Cancer [Internet]. 2018;18(12):758-66.

Available

at: http://dx.doi.org/10.1038/s41568-018-0073-9

46. Bhat P, Kriel J, Shubha Priya B, Basappa, Shivananju NS, Loos B. Modulating autophagy in cancer therapy: Advancements and challenges for cancer cell death sensitization. Biochem Pharmacol [Internet]. 2018;147:170-82. Available at: https://doi.org/10.1016/j.bcp.2017.11.021 
47. Mathew R, Karantza-Wadsworth V, White E. Role of autophagy in cancer. Nat Rev Cancer. 2007;7(12):961-7.

48. Rybstein MD, Bravo-San Pedro JM, Kroemer G, Galluzzi L. The autophagic network and cancer. Nat Cell Biol [Internet]. 2018;20(3):24351. Available at: http://dx.doi.org/10.1038/s41556-018-0042-2

49. Mauthe M, Orhon I, Rocchi C, Zhou X, Luhr M, Hijlkema K-J, et al. Chloroquine inhibits autophagic flux by decreasing autophagosomelysosome fusion. Autophagy [Internet]. 3 de agosto de 2018;14(8):143555. Available at: https://doi.org/10.1080/15548627.2018.1474314

50. ANVISA. Difosfato de cloroquina [Internet]. 2019. p. 1-5. Available at: http://www.anvisa.gov.br/datavisa/fila_bula/frmVisualizarBula.asp?pNuTra nsacao $=7313942015 \&$ pldAnexo $=2805311$

51. ANVISA. REUQUINOL ${ }^{\circledR}$ Apsen Farmacêutica S.A. Comprimidos Revestidos $400 \mathrm{mg}$ [Internet]. 2019. Available at: http://www.anvisa.gov.br/datavisa/fila_bula/frmVisualizarBula.asp?pNuTra nsacao $=9097152015 \&$ pldAnexo $=2895239$

52. Bedoya V. Effect of Chloroquine on Malignant Lymphoreticular and Pigmented Cells in Vitro. Cancer Res. 1970;30(5):1262-75.

53. Murakami N, Oyama F, Gu Y, McLennan IS, Nonaka I, Ihara Y. Accumulation of Tau in Autophagic Vacuoles in Chloroquine Myopathy. $J$ Neuropathol Exp Neurol [Internet]. julho de 1998;57(7):664-73. Available at: https://academic.oup.com/jnen/article-lookup/doi/10.1097/00005072199807000-00003

54. Goldberg SB, Supko JG, Neal JW, Muzikansky A, Digumarthy S, Fidias $P$, et al. A Phase I Study of Erlotinib and Hydroxychloroquine in Advanced Non-Small-Cell Lung Cancer. J Thorac Oncol [Internet]. outubro de 2012;7(10):1602-8. Available at: https://linkinghub.elsevier.com/retrieve/pii/S1556086415326034

55. Zou Y, Ling YH, Sironi J, Schwartz EL, Perez-Soler R, Piperdi B. The 
autophagy inhibitor chloroquine overcomes the innate resistance of wildtype EGFR non-small-cell lung cancer cells to erlotinib. J Thorac Oncol. 2013;8(6):693-702.

56. Liu F, Shang Y, Chen SZ. Chloroquine potentiates the anti-cancer effect of lidamycin on non-small cell lung cancer cells in vitro. Acta Pharmacol Sin [Internet]. 2014;35(5):645-52. Available at: http://dx.doi.org/10.1038/aps.2014.3

57. Shen W, Zhang X, Fu X, Fan J, Luan J, Cao Z, et al. A novel and promising therapeutic approach for NSCLC: Recombinant human arginase alone or combined with autophagy inhibitor. Cell Death Dis [Internet]. 2017;8(3):e2720-11. Available at: http://dx.doi.org/10.1038/cddis.2017.137

58. Marmor MF, Kellner U, Lai TYY, Melles RB, Mieler WF. Recommendations on Screening for Chloroquine and Hydroxychloroquine Retinopathy (2016 Revision). Ophthalmology [Internet]. junho de 2016;123(6):1386-94. Available at: http://dx.doi.org/10.1016/j.ophtha.2016.01.058

59. Papanastasiou I, Prousis KC, Georgikopoulou K, Pavlidis T, Scoulica E, Kolocouris N, et al. Design and synthesis of new adamantyl-substituted antileishmanial ether phospholipids. Bioorganic Med Chem Lett [Internet]. 2010;20(18):5484-7. Available

at: http://dx.doi.org/10.1016/j.bmcl.2010.07.078

60. Alam MM, Joh EH, Kim Y, Oh Y II, Hong J, Kim B, et al. Synthesis and biological evaluation of cyclopentane-linked alkyl phosphocholines as potential anticancer agents that act by inhibiting Akt phosphorylation. Eur $J$ Med Chem [Internet]. 2012;47(1):485-92. Available at: http://dx.doi.org/10.1016/j.ejmech.2011.11.018

61. Berman HM, Westbrook J, Feng Z, Gilliland G, Bhat TN, Weissig H, et al. The Protein Data Bank. Nucleic Acids Res [Internet]. 1 de janeiro de 2000;28(1):235-42. Available at: https://academic.oup.com/nar/article- 
lookup/doi/10.1093/nar/28.1.235

62. Ausubel F, Brent R, Kingston RE, Moore DD, Seidman JG, Smith JA, et al. Short protocols in molecular biology, 5th ed. John Wiley Sons. 2002;1500.

63. Tang X, Liang X, Li M, Guo T, Duan N, Wang Y, et al. ATF6 pathway of unfolded protein response mediates advanced oxidation protein productinduced hypertrophy and epithelial-to-mesenchymal transition in HK-2 cells. Mol Cell Biochem. 2015;407(1-2):197-207.

64. Kupsco A, Schlenk D. Oxidative Stress, Unfolded Protein Response, and Apoptosis in Developmental Toxicity. In: Science (New York, NY) [Internet]. $2015 . \quad$ p. 1-66. Available at: http://www.ncbi.nlm.nih.gov/pubmed/25792328

65. Hong F, Liu B, Wu BX, Morreall J, Roth B, Davies C, et al. CNPY2 is a key initiator of the PERK-CHOP pathway of the unfolded protein response. Nat Struct Mol Biol [Internet]. 2017;24(10):834-9. Available at: http://dx.doi.org/10.1038/nsmb.3458

66. Spence MM, Hui RL, Chang JT, Schottinger JE, Millares M, Rashid N. Treatment patterns and overall survival associated with first-line systemic therapy for patients with advanced non-small cell lung cancer. J Manag Care Spec Pharm. 2017;23(2):195-205.

67. Carew JS, Kelly KR, Nawrocki ST. Autophagy as a target for cancer therapy: new developments. Cancer Manag Res [Internet]. 2012;4:35765. Available at: http://www.ncbi.nlm.nih.gov/pubmed/23091399

68. Doroshow DB, Herbst RS. Treatment of Advanced Non-Small Cell Lung Cancer in 2018. JAMA Oncol [Internet]. 2018;4(4):569. Available at: http://oncology.jamanetwork.com/article.aspx?doi=10.1001/jamaoncol.20 17.5190

69. Goodman LS, Gilman AG. Goodman \& Gilman: As bases farmacológicas da terapêutica. 10th ed. Hardman JG, Limbird LE, organizadores. Rio de 
Janeiro: McGraw-Hill; 2005.

70. Bradbury P, Sivajohanathan D, Chan A, Kulkarni S, Ung Y, Ellis PM. Postoperative Adjuvant Systemic Therapy in Completely Resected NonSmall-Cell Lung Cancer: A Systematic Review. Clin Lung Cancer [Internet]. 2017;18(3):259-273.e8. Available at: http://dx.doi.org/10.1016/j.cllc.2016.07.002

71. Lu H, Jiang Z. Advances in antiangiogenic treatment of small-cell lung cancer. Onco Targets Ther. 2017;10:353-9.

72. Raphael J, Chan K, Karim S, Kerbel R, Lam H, Santos K delos, et al. Antiangiogenic Therapy in Advanced Non-small-cell Lung Cancer: A Meta-analysis of Phase III Randomized Trials. Clin Lung Cancer. 2017;18(4):345-353.e5.

73. Ren J-H, He W-S, Nong L, Zhu Q-Y, Hu K, Zhang R-G, et al. Acquired Cisplatin Resistance in Human Lung Adenocarcinoma Cells Is Associated with Enhanced Autophagy. Cancer Biother Radiopharm [Internet]. 2010;25(1):75-80. Available

at: http://www.liebertpub.com/doi/10.1089/cbr.2009.0701

74. Sirichanchuen B, Pengsuparp T, Chanvorachote P. Long-term cisplatin exposure impairs autophagy and causes cisplatin resistance in human lung cancer cells. Mol Cell Biochem [Internet]. 2012;364(1-2):11-8. Available at: http://link.springer.com/10.1007/s11010-011-1199-1

75. Wu H-M, Jiang Z-F, Ding P-S, Shao L-J, Liu R-Y. Hypoxia-induced autophagy mediates cisplatin resistance in lung cancer cells. Sci Rep [Internet]. 23 de dezembro de 2015;5(1):12291. Available at: http://dx.doi.org/10.1038/srep12291

76. Jagannathan S, Malek M a Y a, Malek E, Vad N, Latif T, Anderson KC, et al. Pharmacologic screens reveal metformin that suppresses GRP78dependent autophagy to enhance the anti-myeloma effect of bortezomib. Leukemia [Internet]. 2015;29(11):1-27. Available at: http://www.nature.com/doifinder/10.1038/leu.2015.157 
77. Xie W-Y, Zhou X-D, Yang J, Chen L-X, Ran D-H. Inhibition of autophagy enhances heat-induced apoptosis in human non-small cell lung cancer cells through ER stress pathways. Arch Biochem Biophys [Internet]. outubro de 2016;607:55-66. Available at: http://www.embase.com/search/results?subaction=viewrecord\&from=exp ort\&id=L611826500\%0Ahttp://dx.doi.org/10.1016/j.abb.2016.08.016

78. Wang Y, Kuramitsu Y, Baron B, Kitagawa T, Tokuda K, Akada J, et al. CGK733-induced LC3 II formation is positively associated with the expression of cyclin-dependent kinase inhibitor p21Waf1/Cip1 through modulation of the AMPK and PERK/CHOP signaling pathways. Oncotarget. 2015;6(37):39692-701.

79. Ravanan P, Srikumar IF, Talwar P. Autophagy: The spotlight for cellular stress responses. Life Sci. 2017;188(August):53-67.

80. Mitani T, Minami M, Harada N, Ashida H, Yamaji R. Autophagic degradation of the androgen receptor mediated by increased phosphorylation of p62 suppresses apoptosis in hypoxia. Cell Signal [Internet]. outubro de 2015;27(10):1994-2001. Available at: http://dx.doi.org/10.1016/j.cellsig.2015.07.009

81. Meng X-X, Yao M, Zhang XD, Xu H-X, Dong Q. ER stress-induced autophagy in melanoma. Clin Exp Pharmacol Physiol [Internet]. agosto de 2015;42(8):811-6. Available at: http://doi.wiley.com/10.1111/14401681.12436

82. Vermes I, Haanen C, Steffens-Nakken H, Reutelingsperger C. A novel assay for apoptosis. Flow cytometric detection of phosphatidylserine expression on early apoptotic cells using fluorescein labelled Annexin V. J Immunol Methods [Internet]. 17 de julho de 1995;184(1):39-51. Available at: https://linkinghub.elsevier.com/retrieve/pii/002217599500072/

83. Riccardi C, Nicoletti I. Analysis of apoptosis by propidium iodide staining and flow cytometry. Nat Protoc [Internet]. 9 de agosto de 2006;1(3):145861. Available at: http://www.nature.com/articles/nprot.2006.238 
84. Ly JD, Grubb DR, Lawen A. The mitochondrial membrane potential (deltapsi $(m)$ ) in apoptosis; an update. Apoptosis [Internet]. 2003;8(2):11528. Available at: http://www.ncbi.nlm.nih.gov/pubmed/12766472

85. Tai H, Wang Z, Gong H, Han X, Zhou J, Wang X, et al. Autophagy impairment with lysosomal and mitochondrial dysfunction is an important characteristic of oxidative stress-induced senescence. Autophagy [Internet]. 2 de janeiro de 2017;13(1):99-113. Available at: https://www.tandfonline.com/doi/full/10.1080/15548627.2016.1247143

86. Cong L, Ran FA, Cox D, Lin S, Barretto R, Habib N, et al. Multiplex Genome Engineering Using CRISPR/Cas Systems. Science (80- ) [Internet]. 15 de fevereiro de 2013;339(6121):819-23. Available at: http://www.sciencemag.org/cgi/doi/10.1126/science.1231143

87. Noda T, Matsunaga K, Taguchi-Atarashi N, Yoshimori T. Regulation of membrane biogenesis in autophagy via PI3P dynamics. Semin Cell Dev Biol [Internet]. setembro de 2010;21(7):671-6. Available at: http://dx.doi.org/10.1016/j.semcdb.2010.04.002

88. Mizushima N. The role of the Atg1/ULK1 complex in autophagy regulation. Curr Opin Cell Biol [Internet]. abril de 2010;22(2):132-9. Available at: http://dx.doi.org/10.1016/j.ceb.2009.12.004

89. Kim YC, Guan K. mTOR: a pharmacologic target for autophagy regulation. J Clin Invest [Internet]. 2 de janeiro de 2015;125(1):25-32. Available at: http://www.jci.org/articles/view/73939

90. Tseng H, Gage JA, Shen T, Haisler WL, Neeley SK, Shiao S, et al. A spheroid toxicity assay using magnetic $3 \mathrm{D}$ bioprinting and real-time mobile device-based imaging. Sci Rep [Internet]. 14 de novembro de 2015;5(1):13987. Available at: http://dx.doi.org/10.1038/srep13987

91. Cooper JR, Abdullatif MB, Burnett EC, Kempsell KE, Conforti F, Tolley H, et al. Long Term Culture of the A549 Cancer Cell Line Promotes Multilamellar Body Formation and Differentiation towards an Alveolar Type II Pneumocyte Phenotype. Cappello F, organizador. PLoS One 
[Internet]. 28 de outubro de 2016;11(10):e0164438. Available at: https://dx.plos.org/10.1371/journal.pone.0164438 